\title{
The Price of Admission: Causes, Effects, and Patterns of Conditions Imposed on States Entering the Union
}

\author{
by ERIC BIBER*
}

\section{INTRODUCTION}

A few years after the Civil War ended, the Congress debated whether and how to admit the Nebraska Territory as a member of the Union. The country continued to be torn apart by political crises over the Reconstruction of the Southern states and over the political and civil rights to be granted to the newly-freed slaves. So it is not especially surprising that a particular point of the debate was the imposition of a requirement on Nebraska that it provide for black suffrage in its new state constitution before it could be admitted as a state. What may be surprising to a modern reader were some of the arguments used by those congressmen opposed to the imposition of a black suffrage requirement on Nebraska. For example, Sen. Wade of Ohio argued:

This state has never yet committed an act by which she forfeited her rights. If a state has raised her hand against your Constitution, if by rebellion she has forfeited her right to exist, she has then placed herself in a position where you have a constitutional right to deal with her just as you please. But I do not know what right you have to deal in this way with a State or a Territory which has been always loyal. 1

Another senator added: "What we call loyalty, therefore, seems to me to be the great prerequisite to the admission of a people to a share in this Government. . . . So far as I know that constituency I believe they are as loyal as the people of any other portion of the country?"2

The debate over the admission of Nebraska, and the imposition of a condition on its admission, was seen by many contemporaries as a question of loyalty, or a state's (or more accurately, the population of a state's) fitness to be a member of the Union. The opponents of imposing conditions on Nebraska characterized conditions as a tool to be used where a

*J.D., Yale Law School, 2001; M.E.Sc., Yale School of Forestry and Environmental Studies, 2001. Many thanks to Judith Resnik, Bruce Ackerman, and Marc Falkoff for their assistance and comments on this essay.

1. Cong. Globe, 39th Cong., 2d Sess. 126 (1866).

2. Cong. Globe, 39th Cong, 2 d Sess. 315 (remarks of Sen. Howe) (1866). 
state population was of doubtful loyalty, ${ }^{3}$ and where Congress was required to undertake some sort of social engineering in order to ensure that loyalty could be assured. Imposition of the suffrage condition on Nebraska was seen as unfair and unnecessary by a number of congressmen precisely because Nebraska was (in comparison to the recently rebellious Southern states) loyal and could be trusted. Eventually, however, the opponents of the black suffrage condition lost the debate, and Nebraska was required to change its state constitution before it could be admitted. 4

The debate over the admission of Nebraska is not an anomaly in United States history. Of the thirty-seven states admitted to the Union since the adoption of the Constitution (plus the eleven Southern states readmitted after the Civil War), almost all of them have had some sort of condition imposed on them when they were admitted. A review of the types of conditions that have been imposed on admitted states, and the historical context for those conditions, reveals a significant pattern: Congress has imposed conditions on the admission of states where it has concerns about whether the citizenry of the new state can be assimilated as a loyal, democratic unit of government within the United States, sometimes because that citizenry has been perceived as fundamentally different from mainstream American politics and society. These concerns have been expressed in a variety of ways, and thus in a variety of conditions, depending on the historical context. Basic civil liberties, language, religion, race relations, and the structure of the family and marriage have all been elements that Congress has used as touchstones in attempting to reassure itself that the new state will be a loyal member of a homogeneous American federal democratic state. For example, admitted states that had conditions imposed upon them for their admission (or in some cases, readmission) to the Union include Louisiana (predominantly French at the time of its admission in the early $1800 \mathrm{~s}$ ), the Southern states during Reconstruction, Utah (populated by Mormons that were perceived as disloyal and different from the rest of the Union), and New Mexico (with a substantial Mexican population). These conditions have also often been part of a broader process of assimilation and "Americanization" which the admitted state went through-voluntarily or not-in order to become a member of the Union. And in imposing these conditions, Congress has legislated in a wide range of fields, ranging from family law, to criminal procedure, to suffrage, to official language. Thus, Congress has not limited itself to the substantive areas listed in its enumerated powers in Article I of the Constitution-nor has it been limited to the substantive areas that the Supreme Court has sometimes characterized as

3. In referring to Nebraska, one Representative stated that Nebraska is "a Territory that is loyal, [has a] people that are patriotic, and [will be] a State, if it becomes one, which will fulfill all its duties." CONG. GloBe, 39th Cong., 2d Sess. 456 (remarks of Rep. Banks) (1866).

4. Nebraska Enabling Act $\S 4$, ch. 59, 13 STAT. 47 (1864). 
traditionally federal or state. 5

The use of admission conditions as a Congressional tool in imposing homogeneity and expanding the scope of federal power provides an important insight into the division of sovereignty among the federal and state governments and the nature of that sovereignty. A federal system, such as the United States of America, is based on two levels of sovereignty-that of a federal government, and that of a collection of subsidiary units (in the case of the United States, state governments). But this division of sovereignty among the federal and state governments raises the question of what the nature of sovereignty is-instead of being the indivisible, overarching, and final word in matters of government, both sovereigns must somehow share their supremacy. This requirement means that somehow the borders between where one sovereignty ends and where another one begins must be drawn, and (perhaps) policed by one political authority or another.

The history of admission conditions provides an important empirical resource for exploring the sharing of sovereignty within the U.S. federal system that has hardly been studied at all. ${ }^{6}$ The very moment that a state is admitted to the Union is often also the moment of the creation of a state

5. See United States v. Morrison, 529 U.S. 598, 616 (2000) (describing family law as an area "of traditional state regulation"); United States v. Lopez, 514 U.S. 549, 564-65 (1995) (describing criminal law, education and family law as areas of traditional state regulation).

6. One historian has explored the process of statehood formation and the admission process. See Peter S. Onuf, Statehood and Union (1987); Peter S. Onuf, New Stale Equality: The Ambiguous History of a Constitutional Principle, 18 Publuus 53, 53 (1988); Peter S. Onuf, Territories and Statehood, in EnCyClopedia of American Political History 1283 (Jack P. Greene, ed. 1984). Statehood and Union focuses exclusively on the Northwest Ordinance and the process of statehood for the states of the Old Northwest, and while it does discuss to some extent the issues explored in this paper, see generally Chaps. 1 $\& 2$, it provides a broader analysis of the role that the Northwest Ordinance played in establishing the process by which territories became states, whether there was a "right to statehood," the prohibition of slavery in the Old Northwest, boundary disputes between states, and land settlement. For a discussion of New State Equality, see n.270, infra. A recent study provided a historical overview of the process of admission, the conditions imposed by Congress on state admission, and the case law concerning those conditions; the study, however, was focused on the implications for the admission of Puerto Rico as a state, and was explicitly intended as an advocacy brief for Puerto Rican statehood. Grupo DE Investigadores Puertorriquenos, Breakthrough from Colonialism: An INTERDISCIPLINARY STUDY OF STATEHOOD 63-64 (1984) [hereinafter BREAKTHROUGH]; see also Luis R. Davila-Colon, Equal Citizenship, Self-Determination and the U.S. Statehood Process: A Constitutional and Historical Analysis, 13 CASE W. RES. J. INT'L L. 315, (1981) (a summary of the larger study). Two law review articles have examined two of the particular conditions that have been imposed on states, but have not provided a broader context for their analysis. See Lawrence N. Park, Admission of States and the Declaration of Independence, 33 TeMPLE L. Q. 403, 405 (1960); Robert F. Utter \& Edward J. Larson, Church and State on the Frontier: The History of the Establishment Clauses in the Washington State Constitution, 15 HASTINGS CoNST. L. Q. 451, 458-461 (1988). There are a small number of articles on the "equal footing" doctrine of the Supreme Court, which limits the types of admission conditions that will be judicially enforced. See notes 270 infra and articles cited therein. However, these articles exclusively discuss the issue of federal control over public lands in the states, and whether the federal government may exercise jurisdiction 
as a sovereign unit. Thus, this process provides an important historical insight about how Congress, the courts, and Americans in general have viewed historically the appropriate scope of sovereignty for the states versus the federal government. But besides one significant Supreme Court case, Coyle v. Smith ${ }^{7}$, and the attention that case has received ${ }^{8}$, the topic has been understudied.

over federal lands in states consistent with the "equal footing" doctrine. A few scholars writing more than fifty years ago have also explicitly analyzed the constitutional and legal status of admission conditions. See William A. Dunning, Are the States Equal Under the Constitution? 3 POL. Scl. Q. 425, 429 (1888); John Hanna, Equal Footing in the Admission of States, 3 BAYlor L. REV. 519 (1951); Charles O. Lerche, Jr., The Guarantee of a Republican Form of Government and the Admission of New States, 11 J. PoL. 578, 589-91 (1949); Julien C. Monnet, Violations by a State of the Conditions of Its Enabling Act, 10 Colum. L. Rev. 591 (1910); George W. Wickersham, New States and Constitutions, 21 YALE L.J. 1 (1911). Finally, Wiecek has provided a detailed analysis of the use of the Guarantee Clause by Congress, a clause which was used by the Republicans during the Civil War and Reconstruction to justify, in part, the imposition of conditions on states; however, Wiecek's analysis is limited to these particular examples and to the interpretations and use of the Guarantee Clause. William M. Wiecek, The Guarantee Clause of the U.S. Constitution 203-205 (1972).

7. 221 U.S. 559 (1911). In Coyle, Oklahoma sought to move its state capital from Guthrie to Oklahoma City, despite a condition in the Enabling Act providing for Oklahoma's admission in which Congress had required Oklahoma to keep its capital in Guthrie until 1913. The Supreme Court held that such a condition violated the "equal footing" doctrine - Congress would not have had such a power to legislate over a state's capital location for a state already in the Union, and so Congress could not impose such a condition on a state when it admitted that state.

8. For later U.S. Supreme Court cases that cite and discuss Coyle, see Minnesota v. Mille Lacs Band of Chippewa Indians, 526 U.S. 172, 203-204 (1999) (stating that treaty rights of Indians are not extinguished by the admission of a state to the Union); New York v. U.S., 505 U.S. 144, 162 (1992) (striking down federal law that required states to take title to low-level radioactive waste within their borders); Heath v. Alabama, 474 U.S. 82, 89 (1985) (upholding successive prosecutions for murder by two states for the same conduct against a double jeopardy challenge becausc cach state is its own sovereign); National League of Cities $v$. Usery, 426 U.S. 833, 845-46 (1976) (relying in part on Coyle to hold that federal regulation of state employee wages under the Fair Labor Standards Act intrudes so much on "traditional governmental functions" that it violates the Tenth Amendment); South Carolina v. Katzenbach, 383 U.S. 301, 328-29 (1966) (upholding provision of Voting Rights Act that provides stricter review of voting laws in Southern states against challenge that it violates "equal footing" doctrine); Skiriotes v. Florida, 313 U.S. 69 (1941) (upholding Florida law that regulated taking of sealife by Florida residents in the high seas as part of the inherent sovereignty of all states); Joplin Mercantile Co. v. United States, 236 U.S. 531 (1915) (upholding a provision of Oklahoma's Enabling Act that required the state to prohibit sales of liquor to Indians); see also Garcia v. San Antonio Metropolitan Transit Authority 469 U.S. 528, 556 (1985) (overruling National League of Cities); id. at 574 (Rehnquist, J., dissenting). The scholarly commentary on Coyle v. Smith and the history of admission conditions has been very cursory in general. See, e.g., LaUREnce H. Tribe, American Constitutional Law \$\$5-20 \& 5-22, at 378-397 (discussing state sovereignty limits on Congressional power, noting that Coyle $v$. Smith is an example of a case in which the Court has limited federal power to regulate state governments, and stating that South Carolina $v$. Katzenbach has limited Coyle to the narrow holding that Congress must Ireat states equally in admitting them); Bradford R. Clark, Translating Federalism: A Structural Approach, 66 Geo. WASH. L. Rev. 1 161, 1195-96 (1998) (arguing that Coyle stands as a precedent that supports current Supreme Court jurisprudence that the federal government lacks the power to "compel the States to enact or administer a federal 
The historical context of admission conditions reveals a federal system in which state sovereignty at the very moment of its creation is subsidiary to the unity and stability of the federal government as a wholeeven before the Civil War. Congress has always been concerned with the potential loyalty of the new state, and was willing and able to take steps to provide at least symbolic, and sometimes quite effective, measures to ensure that the state would be thoroughly Americanized and made part of a harmonious Union of states. The importance of cohesion and unity in the federal system has trumped the independence and sovereignty of the individual members of the federal system at the very moment when those members were brought into being.

The lessons drawn from admission conditions have significant implications for modern constitutional law and current Supreme Court jurisprudence. Coyle v. Smith is the most famous and most significant case in the field of admission conditions. Because of its holding limiting the power of Congress to impose conditions on newly-admitted states, it has been cited by the Supreme Court as an important example of the basic nature of state sovereignty in the federal system, and of its core, inviolable features. ${ }^{9}$ But Coyle does not stand in a vacuum, either in the case law or in the historical context of admission conditions. Long before Coyle, the courts had been

regulatory program"); Martha A. Field, Garcia v. San Antonio Metropolitan Transit Authority: The Demise of a Misguided Doctrine, 99 HARV. L. REV. 84, 113 (1985) (characterizing the facts of Coyle as an extreme example of federal intrusion in which one "would expect a holding of unconstitutionality"); Deborah Jones Merritt, The Guarantee Clause and State Autonomy: Federalism for a Third Ceniury, 88 CoLum. L. Rev. 1, $41-42$ (1988) (citing Coyle as an example of the Court placing limits on federal regulation of state government); Thomas H. Odom, The Tenth Amendment After Garcia: Process-Based Procedural Protections, $135 \mathrm{U}$ PA. L. REv. I657, 1663 (1987) (stating that the Court's citation to Coyle in Garcia implies that there are some substantive limitations to federal regulation of state governmental powers, and exploring various alternatives in the scholarly literature as to what those limitations might be); James R. Rasband, The Disregarded Common Parentage of the Equal Footing and Public Trust Doctrines, 32 LAND \& WATER L. REv. 1, 50-56 (1997) (stating that Coyle represents a constitutional aspect of the equal footing doctrine). Other scholars have discussed Coyle $v$. Smith in the context of the "equal footing" doctrine and federal ownership of public lands. Jonathan K. Waldrop, Note: Rousing the Sleeping Giant? Federalism and the Guarantee Clause, 15 J. L.\& PoL. 267, 290 n.123 (1999) (citing to Coyle as an example of a case where the Court protected state governmental processes against federal government intrusion); see discussion in note 270 infra, and accompanying text; see also Carolyn $\mathrm{M}$. Landever, Whose Home on the Range? Equal Footing, the New Federalism, and State Jurisdiction on Public Lands, 47 FLA. L. REv. 557, 565, 590-91 (1995) (arguing that Coyle establishes a guarantee of equal footing and state sovereignty to all states, which should include economic and property interests for the states as well as political interests).

9. See New York v. U.S., 505 U.S. 144, 162 (1992) (striking down a federal law that required states to take title to low-level radioactive waste within their borders and citing Coyle for the proposition that "The Constitution has never been understood to confer upon Congress the ability to require the States to govern according to Congress's instructions"); National League of Cities v. Usery, 426 U.S. 833, 845-46 (1976) (relying in part on Coyle to hold that federal regulation of state employee wages under the Fair Labor Standards Act intrudes so much on "traditional governmental functions" that it violates the Tenth Amendment). 
attempting to restrict Congressional power to use admission conditionsyet, Congress continued to impose conditions on states through the Twentieth Century. Moreover, those conditions-and the assimilation movement of which the conditions were a part-often had profound impacts on the politics and society of the states on which they were imposed. While the rhetoric and holding of Coyle-no condition can be imposed on a state that would otherwise be outside of Congress's power to legislate for any other state-may be strong, the impact of Coyle (and the case law of which it was a part) appears to have been relatively minimal.

In citing to Coyle in its Tenth and Eleventh Amendment jurisprudence, the Supreme Court has relied on the rhetoric and holding of Coyle. ${ }^{10}$ But given the historical context of Coyle-the effective manner in which Congress has imposed homogeneity on newly-admitted states, in part through the use of admission conditions--the citations to Coyle appear to be problematic if the goal is to help construct a vision of inviolable state sovereignty protected by clear limits on the scope of federal power. Even where Coyle has not been directly cited in the Court's Tenth and Eleventh Amendment jurisprudence, ${ }^{11}$ the history of the use of conditions-used unequally against states that are perceived as different or disloyal, in areas far removed from the enumerated federal powers of Article I, and to subordinate states to an overarching federal system-raises questions about the historical grounding for the Court's legal conclusions. Instead, the history of admission conditions might indicate the Court should be taking a more subtle, nuanced approach to its state sovereignty cases.

This paper explores in detail the history of conditions imposed on the admission of particular states. It begins with an overview of the process of admitting new states to the Union and of the conditions imposed by Congress on the entering states. It then explores the reasons why Congress imposed certain conditions on states. Finally, the paper examines the effectiveness of those conditions, both in terms of judicial enforcement and in terms of whether the conditions (and the broader process of assimilation that they were a part of) succeeded in changing the government and society of the states on which they were imposed.

\section{THE PROCESS OF ADMITTING NEW STATES AND AN OVERVIEW OF CONDITIONS IMPOSED}

Congress has the power to admit new states to the Union. 12 However, the Constitution does not explicitly address either the procedure for admis-

10. See cases cited in note 9 , supra.

11. See, e.g., Alden v. Maine, 527 U.S. 706 (1999); United States v. Lopez, 514 U.S. 549 (1995).

12. "New States may be admitted by the Congress into this Union." U.S. ConsT. art. IV, $\$ 3, \mathrm{cl} . \mathrm{l}$. 
sion, or whether Congress's power to admit new states is limited in any form.

The debates in the Constitutional Convention do not include much discussion of Congress's power to admit new states. The discussion and amendments that did occur appear to indicate that the Convention intended to give Congress as broad a power as possible in admitting states. ${ }^{13}$ The Convention explicitly rejected requiring unanimous consent for the admission of new states, ${ }^{14}$ and also explicitly rejected requiring a twothirds vote for admission. ${ }^{15}$ The Convention also removed a provision that would have required all new states to be admitted on an equal footing with the original states. 16 The removal of the equal footing requirement was prompted by a motion of Gouverneur Morris, who proposed the final language giving plenary power to Congress. Historian William Dunning, citing letters from Morris, stated that Morris's goal was to give Congress the power to impose conditions on admitted states, including depriving them of any rights in Congress. Morris believed that if Canada or Louisiana were acquired, they should be governed "as provinces" and not allowed any "voice in our counsels." 17

Historical precedent and judicial caselaw, not constitutional text or original intent, has therefore determined the scope of Congress's power to admit states, and what concessions Congress can constitutionally, politically, and practically obtain from the states-to-be-admitted.

\section{A. The Process of Admission}

Through the admission of thirty-seven new states to the Union (and the readmission of eleven seceded states during Reconstruction), Congress has developed a general process for the admission of new states, albeit a process which is rarely followed precisely in individual cases. An intro-

13. The greatest concem in the Convention appeared to have been the status of Vermont, which at the time was considered by New York to be a rebellious district. Delegates from New England and other small states feared that the provisions of what was to become Article IV Section 3 Clause 2, which required the consent of a state for the separation of a part of that state as a new state, would force the United States to subjugate Vermont upon the demand of New York. See The Debates in the Federal Convention of 1787 Which Framed the Constitution of the United States of America Reported by James MAdison 488 (Gaillard Hunt \& James Brown Scott eds., 1999) [hereinafter Convention Debates]; Peter S. Onuf, Vermont and the Union, in A More Perfect Union: Vermont Becomes A STATE, 1777-1816, at 150, 151-53 (Michael Sherman ed., 1991). A compromise required the consent of a state for any future separation of a new state "hereafter formed." This exempted Vermont, which was already considered to be "formed." See Convention Debates at 491; Onuf, Vermont and the Union, supra, at 154.

14. See Convention Debates at 58 .

15. See id. at 487-492.

16. See id. at 487-88.

17. William A. Dunning, Are the States Equal Under the Constitution? 3 PoL. SCI. Q. 425,429 (1888). 
duction to the process will also enable the reader to follow the sometimes complex twists and turns of the individual stories of state admissions.

The Northwest Ordinance of 1784 is well-known for establishing the basic principles for the creation of new states within the United States. 18 Territorial status, with varying levels of self-government (depending on population and/or political circumstances) was established by the Ordinance as the predecessor to statehood, and this precedent has been followed throughout U.S. history. ${ }^{19}$ Historically, there have been great variations in the duration of territorial status-states may be admitted without ever becoming territories, or territorial status can last for years, or decades. ${ }^{20}$

18. Northwest Ordinance of 1787 , reprinted in ThE NORThwest Ordinance 1787: A Bicentennial HandBook 31-77 (Robert M. Taylor, Jr. ed. 1987), and in 2 The Terrtorial Papers of THE United States 39-50 (Clarence E. Carter, ed. 1934). For books discussing the important role of the Northwest Ordinance in establishing the system by which the Western frontier was to be settled, governed, and admitted into the United States in an organized manner, see THE NORTHWEST ORDINANCE 1787: A BICENTENNIAL HANDBOOK, supra; Pathways to the Old Northwest: AN Observance of the Bicentennial. of the NoRThWEST ORdinance (1988); ONUF, STATEhOOD AND UNION, supra note 6; see also George H. Alden, The Evolution of the American System of Forming and Admitting New States into the Union, 18 AnNals of THE AM. ACAD. PoL. \& SoC. SCl. 469, 479 (1901) ("[W]ith the adoption of the ordinance of 1787 and its ratification by Congress under the Constitution the outlines of the system [of admission of states] were definitely established.")

19. The Northwest Ordinance provided for a governor, officials and judges appointed by Congress as the first stage of territorial government; when a territory had reached a population of five thousand free male inhabitants an elected house of representatives was to be created, which would continue to work with an appointed governor and appointed legislative council. Once the territory had sixty thousand free inhabitants, "such state shall be admitted by its Delegates into the Congress of the United States, on an equal footing with the original States." Art. V of the Northwest Ordinance. Thus, the original scheme was self-government increasing with population.

As time passed, Congress granted self-government for territories soon after a territory was formed, rather than waiting for a certain population level to be reached. See ONUF, STATEHOOD AND UNION, supra note 6 , at 86 (noting the "democratization" of territorial government which "culminated in the organic act for Wisconsin Territory in 1836"); EARL S. Pomeroy, The Territories and the United States: 1861-1890, at 3, 97 (1969); Patrick J. Furlong, Putting the Ordinance to Work in the Northwest, in THE NORTHWEST ORdINANCE 1787: A BICENTENNIAL HANDBOoK, supra note 18, at 103-104 (Robert M. Taylor, Jr. ed, 1987); Peter S. Onuf, Territories and Statehood, supra note 6, at 1284, 1297 (Jack P. Greene, ed. 1984) ("Popular pressure for representative government led to the supersession of first-stage government in many territories before there were 5,000 potential voters."). The Wisconsin Organic Act of 1836 , which provided for a directly elected legislature immediately upon formation of the territory, became the model forever after. Onuf, Territories and Statehood, supra note 6 , at 1298 . However, self-government could be revoked or withheld when Congress believed that the residents of the territory could not be trusted with self-government. The only significant example of Congress restricting self-government for a territory was Utah from the 1870 s through 1890 s. See discussion in Part II, infra. New Mexico and California were both governed for a few years by military governments after their conquest in the Mexican War, and both Orleans and Florida was governed briefly by the military after their purchase. See Jack Ericson Ebsen, The First and Second UnITEd States Empires: GOVERNORS AND TERRITORIAL GOVERNMENT, 1784-1912, at 153 (1968)

20. Compare California (which was admitted almost immediately after cession by Mexico in 1850) and Texas (admitted simultaneously with its annexation by the United 
A variety of factors have determined the transition from territory to state, foremost of them perhaps being population. The Northwest Ordinance had made population a marker for the granting of statehood (promising statehood once sixty thousand free inhabitants were resident). ${ }^{21}$ However, as the years went on, the population threshold system for statehood began to break down, partly because of the rising population of the United States in general (which would have made states with a population of sixty thousand extremely small), and also because of a range of sectional, political and cultural issues, some of which this paper discusses in-depth. As discussed later, the territories that were least "trusted" by the federal government were among the territories that had to wait the longest for statehood, and were admitted with significantly higher populations. ${ }^{22}$

Other factors have also been identified as important for Congress to consider in the admission of a new state, such as majority support in the population for statehood, and the state having enough resources to support state government and to cover its share of the cost of the federal government. ${ }^{23}$ Partisan factors also have played a significant role in the admission of states, leading to significant delays in the admission of states such as North and South Dakota, Montana, and Washington in the $1880 \mathrm{~s}$ because a Democratic Congress was opposed to admission of states likely to support the Republican party. ${ }^{24}$ And slavery, of course, was a major factor in the admission of states before the Civil War.

Admission of a territory to statehood requires at least one Act of Congress (or an equivalent thereof, such as a joint resolution). The process usually begins with Congress passing an enabling act which

States) with New Mexico (which waited over sixty years after being ceded by Mexico to be admitted). See also POMEROY, supra note 19, at xii (noting the substantial periods which most territories spent in territorial status after the Civil War, compared with territories made states before the Civil War).

21. Northwest Ordinance $\$ 9,14$. The question of whether a territory was required to be admitted by Congress once its population reached the sixty thousand mark led to much debate throughout the pre-Civil War period. However, in general the issue was not relevant since many states in the pre-Civil War period were admitted well before they had achieved sixty thousand inhabitants. See EBSEN, supra note 19, at 230-31 tbl. 2; see also ONUF, StatehoOd And UnIon, supra note 6, at 85; Patrick J. Furlong, Putting the Ordinance to Work in the Northwest, supra note 19, at 96-99, 102 (Robert M. Taylor, Jr. ed, 1987).

22. See EBSEN, supra note 19, at 230-231 tbl. 2 (showing that Utah and New Mexico were admitted with substantial populations, after an extended period of territorial status); Breakthrough, supra note 6, at 704, 1387 (noting that New Mexico had the longest period to wait in territorial status before admission, and listing periods until admission for other states); see also EBSEN, supra note 19, at 233 ("By and large, the common practice seems to have been for Congress to pay little attention to the populations when admitting them as states.").

23. See General. accounting Office, Experiences of Past Territories Can assist PUERTo Rico Status Deliberations 11 (1980).

24. See Breakthrough, supra note 6, at 1255-60. 
establishes a process by which a territory can hold a constitutional convention to draft a state constitution and elections for the first state officers and Congressional representatives. ${ }^{25}$ An enabling act can be prompted by petitions from the territory or by Congress's own initiative. 26 The enabling act is important because it is usually the bill which spells out the conditions that Congress expects the new state to meet before (and after) admission; these conditions are often required to be drafted into the new state constitution itself and/or to be part of an "irrevocable" ordinance passed by the state constitutional convention. ${ }^{27}$

After a proposed state constitution has been drafted, the constitution is sent to Congress, which reviews the constitution and passes an admissions act or resolution, approving the constitution and providing for the admission of the state to the Union. ${ }^{28}$ On occasion, Congress might require changes to or interpretations of the state constitution. ${ }^{29}$ Starting in the Civil

25. See, e.g., the enabling acts for Ohio, Illinois, Louisiana, and Montana, Washington, South Dakota and North Dakota. Ohio Enabling Act $\$ \S 1,4-5,2$ Stat. 173 (1802); Louisiana Enabling Act $\S \S 1-4,2$ Stat. 641 (1811); Illinois Enabling Act $\$ \S 1,3-4,3$ Stat. 429 (1818); Omnibus Enabling Act, 25 Stat. 676 (1889). Most of the early states admitted to the Union went through the Enabling Act stage, but from the admission of Arkansas and Michigan until the Civil War Enabling Acts were almost never used, and the territories usually developed on their own a constitution and a petition for statehood that was granted by Congress through an Admission Act (which contained conditions that had to be fulfilled, or were assumed to be fulfilled, by the new state). See EBLEN, supra note 19, at 224-25. During and after the Civil War, Enabling Acts were used again, with only Idaho and Wyoming (of the states admitted after the Civil War and before World War II) entering without Enabling Acts. See id. at 226-228.

Situations where Enabling Acts have not been used usually occurred when the territory/nascent state had already developed its own constitution, and perhaps even already elected its state officers and representatives to Congress. The use of already elected officers and representatives has been termed the "Tennessee Plan," after Tennessee, which used the method successfully to pressure Congress into granting it statehood. The drafting of a constitution by a state, which then submits the proposal to Congress for approval, is a milder version of this pressure. See Breakthrough, supra note 6, at 117-122; Davila-Colon, supra note 6, at 319; Park, supra note 6 , at 405 . This method was adopted by states such as Michigan, Arkansas, California, Idaho and Wyoming. See Breakthrough, supra note 6, at 117-122. Enabling Acts also have not been used when states were carved out from existing states, including Vermont, Kentucky, and West Virginia. See Breakthrough, supra note 6, at 117-122.

26. Compare Colorado, which had voted down a proposed constitution and memorial for statehood before its enabling act was passed, see Elmer Ellis, Colorado's First Fight for Statehood, 1865-1868, 8 CoLo. MAG. 23 (1931), and Nebraska, which had also initially voted down a proposal for statehood, see Albert Watkins, How Nebraska Was Brought into the Union, 18 Publications of THE Neb. STAte Hist. Soc. 375, 378-79 (1917), with New Mexico, which first petitioned for statehood in 1849, after annexation from Mexico, but was not admitted until 1912, Howard RoBerTs Lamar, The FAR Southwest 72-77 (1970).

27. See, e.g., Omnibus Enabling Act $\S 4$ (requiring South Dakota, North Dakota, Montana and Washington to adopt conditions through irrevocable ordinances); Louisiana Enabling Act $\$ 3$ (requiring some conditions to be fulfilled through the state constitution, and others to be fulfilled through an irrevocable ordinance).

28. See, e.g., An Act for the Admission of the State of Louisiana into the Union, and to Extend the Laws of the United States to Said State, 2 Stat. 701 (1812).

29. See, e.g., the example of Missouri, discussed in the Appendix, supra note 344 , and accompanying text. 
War era, Congress began to delegate this stage to the President, who would instead issue a proclamation that a state had been admitted to the Union; 30 however, on occasion Congress would either confirm admission, or overturn the President's decision that admission was not warranted. ${ }^{31}$

\section{B. The History of Conditions}

Congress has imposed conditions on almost every state admitted to the Union since the original thirteen colonies. This Section provides an overview of the subject matter of conditions imposed by Congress.

Conditions have been imposed on some of the earliest states to be admitted to the Union and on the most recent, from Ohio in 1803 to Hawaii in 1959. The number of conditions declined throughout the preCivil War era, a period of strong states rights and sharp sectional conflict over the admission of new states. Immediately during and after the Civil War, conditions became much more frequent and more detailed, with a peak in the admission of the last contiguous states, Arizona, New Mexico, and Oklahoma. Few conditions were imposed on the most recent states, Hawaii and Alaska.

Conditions have spanned a wide substantive range. Many of the conditions involved restrictions on how the states could use, regulate, or dispose of the public lands owned by the United States within their borders. These conditions have consistently been imposed on the states throughout American history and generally prohibited the states from interfering with federal regulation and disposal of the public lands. Public lands conditions also restricted how states could use the lands granted to them by the federal government and protected Indians from state encroachment.

In addition, Congress required certain states to fulfill more far-reaching conditions. As the summary of conditions listed in the Appendix reveals, states such as Louisiana, Utah, Oklahoma, New Mexico, and Arizona faced conditions that regulated areas such as qualifications for public officers, official languages, and family law. During the Civil War and Reconstruction, admission conditions were used by the Republican party in an attempt to shape suffrage and citizenship rules to guarantee black suffrage (and Republican political power) in both Western and Southern states.

Table One provides an overview of these admission conditions.

30. Nevada Enabling Act $\$ 5,13$ Stat. 30, 31-32 (1864). See also Omnibus Enabling Act $\S 8$; New Mexico and Arizona Enabling Act $\$ \$ 4,23$ (1910).

31. See, e.g., Joint Resolution To Admit The Territories of New Mexico and Arizona as States into the Union Upon an Equal Footing with the Original States, 37 Stat. 39 (1911). 


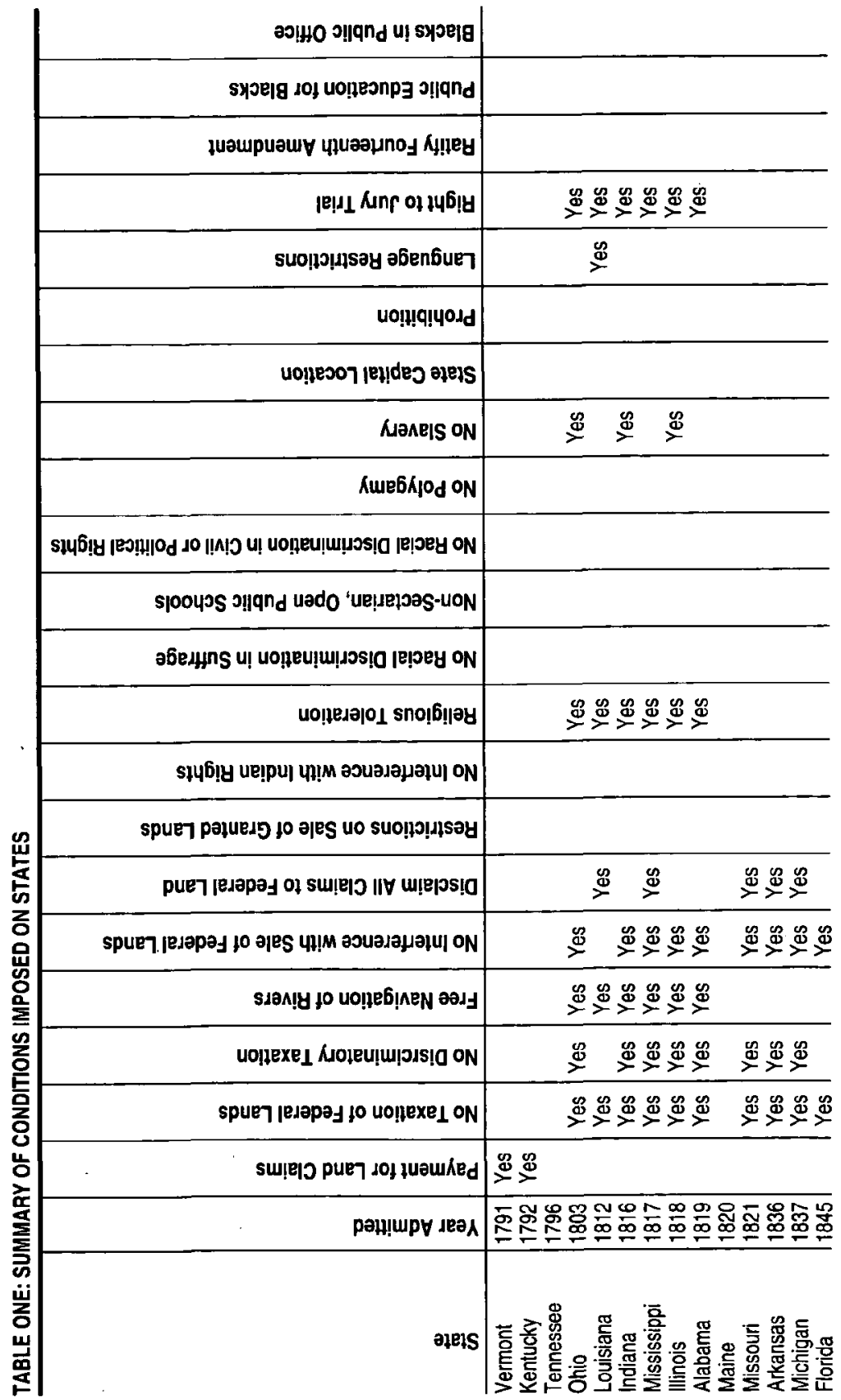




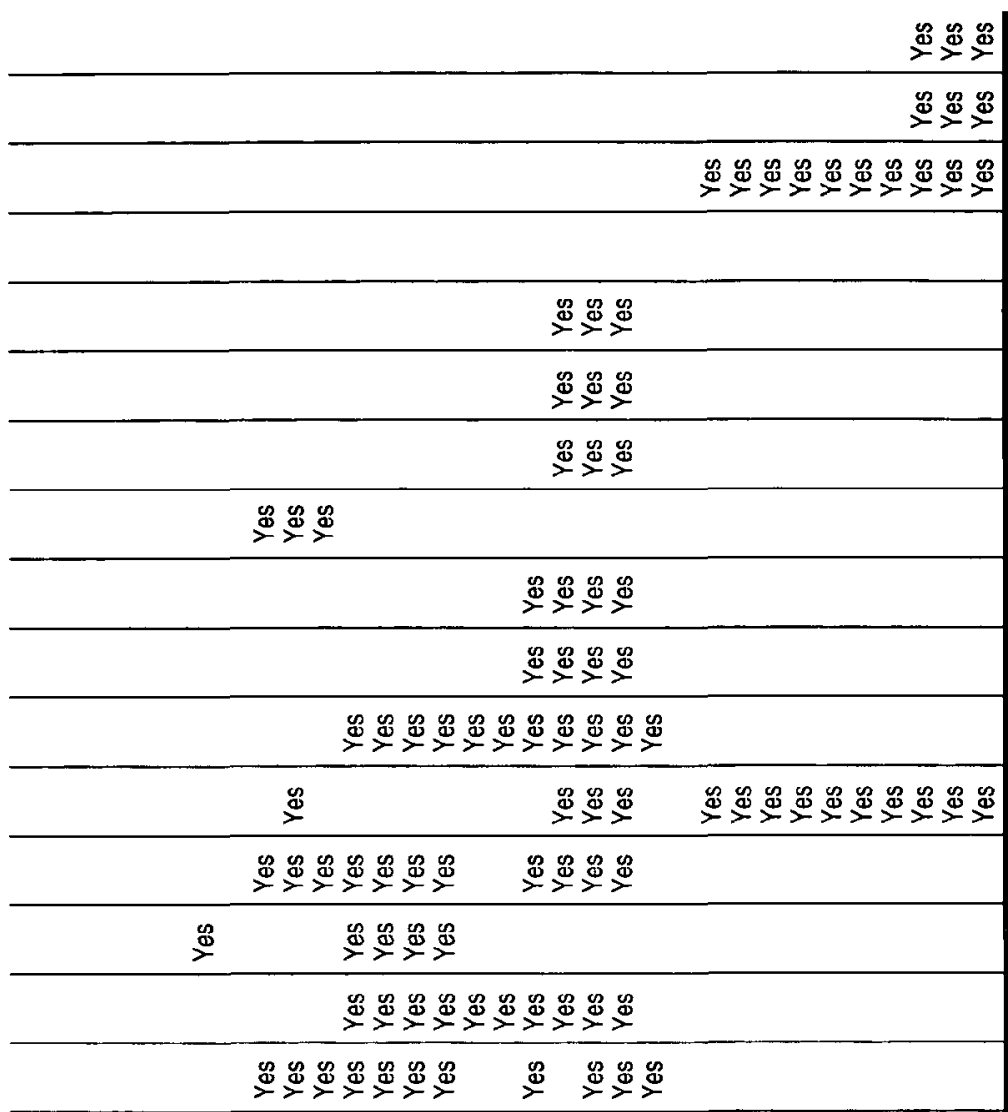

$\stackrel{5}{>}$

$\stackrel{5}{>} \stackrel{\$}{>} \stackrel{\$}{>}$

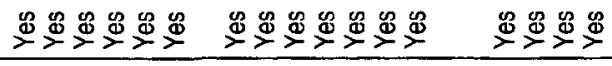

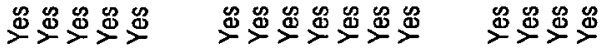

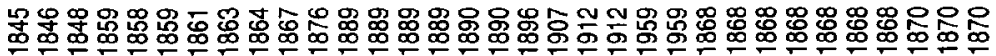

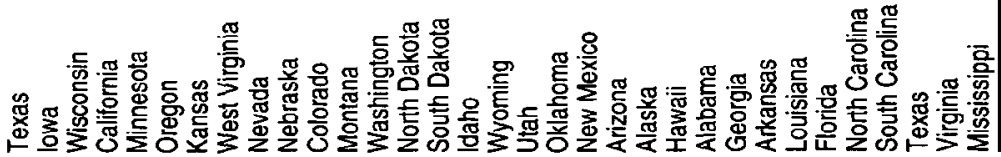




\section{CONDITIONS AS TOOLS TO IMPOSE HOMOGENEITY}

These conditions that intrude into fundamental aspects of state government or society are not uniformly distributed in time or across states. The states of the Northwest Territory (Ohio, Indiana, Illinois, Michigan, Wisconsin) were required to meet the requirements of the Northwest Ordinance, with its broad provisions. Louisiana was required to use English in all official state publications, to use juries and bail in criminal cases, and to respect fundamental liberties. The readmitted Southern states were required to maintain the scope of suffrage in their Reconstruction constitutions; Nebraska (admitted at the same time) was required to not restrict suffrage based on race. Utah was required to prohibit polygamy. New Mexico and Arizona were required to use English in their schools, and to require public officials to speak English.

Why would Congress impose such conditions and why would Congress selectively choose to impose these conditions on these particular states? The common theme-revealed by the legislative history and the broader history of the states and territories in question-is a fear by Congress that the people of the territory about to be admitted could not be trusted with self-government because they were not "American" enough. Conditions were part of a larger process used by Congress to shape a territory's society and government so that it would be loyal, democratic, and more homogenous with respect to the rest of American society. Western settlers in the Northwest Territory, French in Louisiana, rebellious Southerners, Mormons in Utah, and Mexicans in New Mexico were all seen as potential threats to the unity of the United States, and not to be trusted with self-government; conditions were an important tool used by Congress to help assure itself that these elements, once granted the powers of statehood, would not betray the Union.

\section{A. Settlers in the Old Northwest}

In the $1770 \mathrm{~s}, 1780 \mathrm{~s}$, and $1790 \mathrm{~s}$ there was no guarantee that the white settlers who began to move across the Appalachians during and after the Revolution would remain loyal Americans. Throughout the process of the separation of Kentucky from Virginia (a drawn-out process that lasted from the mid-1780s to 1792) and its admission to the Union, there was a constant threat (and a substantial fear among federal officials) that Kentucky might secede or seek annexation by Spain. ${ }^{32}$ The major leaders

32. LowEll H. HARRISON, KENTUCKY'S ROAD TO STATEHOOD 48-72 (discussing the machinations of James Wilkinson with Spanish officials to arrange the independence or annexation of Kentucky). The closure of the Mississippi River by the Spanish on various occasions lent credibility to this threat of secession. Id. at 49, 53; see also JoHN D. 
of the Continental Congress and the first few Congresses under the new Constitution were also concerned with the loyalty of settlers north of the Ohio. ${ }^{33}$ In particular, there was a fear of social anarchy on the wild frontier, anarchy which would prevent self-government and lead to the loss of the West to independence or a foreign power. ${ }^{34}$ The character of the settlers, and the society that they formed, were believed at the time to be essential to the stability of the territories and future unity of the United States west of the Appalachians. 35 "American statesmen had ample reason to doubt the self-governing capacity and basic loyalty of the 'banditti' and 'adventurers' settling the frontiers." 36 The society of the western settlements would therefore have to be shaped through proper controls in order to guarantee that it would develop as a homogenous, self-governing, and loyal society. ${ }^{37}$ The use of social engineering was all the more important

Barnhart, Valley of Democracy: The Frontier versus the Plantation in the Ohio VALLEY: 1775-1818, at 75 (1953). In addition, there were a number of movements for the creation of new and separate states west of the Appalachians throughout the 1770s and 1780 s, including proposals for a "Westsylvania" in southwest Pennsylvania, and "Franklin" in what is now eastem Tennessee. See HARRISON, supra, at 50-65. Such movements must have highlighted the volatility of the political situation among the settlers of the western frontier.

33. See Robert F. Berkhofer, JR., JefFerson, the Ordinance of 1784, and the ORIGINS OF THE AMERICAN TERRITORIAL SYSTEM, 244 (quoting Jefferson expressing the fear that Western settlements "will separate themselves" from Virginia); see also Onuf, Territories and Statehood, supra note 6, at 1297 (stating that American leaders saw the frontiersmen as "distinct and potentially disconnected communities" which might form free and independent republics unconnected to the Union, and so implementation of national policies "required strict limitations on territorial autonomy").

34. Onuf, Statehood and Union, supra note 6, at 6-7 ("American policy makers were impressed - and frightened - by the volatility of the frontier. They were convinced that the federal government's authority and property interests depended on effectively directing the course of western political and economic development."); see also Robert F. Berkhofer, Jr., Jefferson, the Ordinance of 1784, and the Origins of the American Territorial System, 29 WM. \& MARY Q. 3RD SER. 231, 237 (1972) (noting that George Washington proposed restricting the settlement of the Northwest by whites in part because of the need to control unruly settlers "to preserve an orderly, well-regulated white socicty"); id. at 257 (noting fear of Jefferson of secession of Western states); W.P. Cutler, The Ordinance of July / 3 th 1787,1 Ohio ARCHAEOloGical \& Historical Q. 10, 32-33 (1887) (noting the risk of secession by Kentucky and other western territories, and the goal of Congress in framing the Ordinance in ensuring loyalty).

35. Onuf, Statehood and Union, supra note 6, at 21 ("[C]ongressmen were convinced [that] the preservation of the union and the creation of republican governments on the frontier depended on the character of the first settlers."); see also id. at 31,38

36. Onuf, Territories and Statehood, supra note 6, at 1290; see also Robert F. Berkhofer, Jr., The Northwest Ordinance and the Principle of Territorial Evolution, in THE AMERICAN TERrITORIAL SySTEM 45, 50-51 (1973).

37. See Berkhofer, supra note 33, at 244 (noting that political theory at the time required republics to be homogenous to maintain unity, and the difference in interests between Easterners and Westerners, particularly with regard to tariffs and the navigation of the Mississippi, gave great concern to the leaders of the Confederation government). There were also a substantial number of French-Canadians who were resident in the Northwest 
because Jefferson and others involved in developing the territorial system for the Northwest doubted the power of the United States to maintain control over dissatisfied inhabitants by force. 38

The Northwest Ordinance of 1787 (and the Ordinance of 1784 that preceded it) were designed, in part, to model and shape the society and government that would be created in the Northwest. ${ }^{39}$ The Ordinance was sweeping in its scope in shaping the new territorial governments: the territorial government had to respect religious liberty, protect habeas corpus and trial by jury, representative government, bail, prevent cruel and unusual punishments, compensate private property that was taken for public use, and provide public education. ${ }^{40}$ And the Ordinance was not to expire when statehood was achieved. The Ordinance provided that the civil liberties it guaranteed were to be "Articles of compact between the Original States and the People and States in said territory, and forever remain unalterable unless by common consent." 41 It also required that the constitutions of any states formed in the territory should be "in conformity to the principles contained in these Articles." 42 For good measure, the enabling acts for several of the states later carved from the territory required compliance with the provisions of the Ordinance. ${ }^{43}$

Territory in the late $17^{\text {th }}$ Century, and the ability of those residents to govern themselves democratically was doubted by American leaders. See EBLEN, supra note 19, at 45 (noting that if "Congress expected the continued settlement of the Northwest by French-Canadians and other aliens unfamiliar with American political and legal institutions" a stricter control over the territorial government was necessary in order to prevent "anarchy," and that "Monroe said in effect that he wrote his governmental articles specifically for the government of [] 'foreigners', to initiate them into the mysteries of republicanism. In the latter sense, the Ordinance of 1787 was intended to tcach non-English westemers what constitutes a republican government, how it should be organized and how it should operate."); see also $i d$. at 55 ("In 1787, Congress thought that both the French and most Anglo-American settlers were untrustworthy and potentially dangerous."); Rogers M. SMITH, Civic IDEALS: CONFlicting VISIONS OF CITIZENSHIP IN U.S. HISTORY 98 (1997) ("IThe Ordinance] signalled that the French Catholic and Native American territorial populations could have access to U.S. citizenship, but that they would have to conform to the central legal traditions of the nation's Anglo-Saxon heritage."). The first and only territorial governor of the Northwest Territory, Arthur St. Clair, continued to be extremely suspicious of the loyalty of the residents, and their ability to govern themselves (in keeping with his Federalist ideology). See Randolph Chandler Downes, Frontier OHIO: 1788-1803, at 189 (1935) ("St. Clair showed his lack of confidence in his 'subjects' by expressing the sentiment that 'a multitude of indigent and ignorant people are but ill-qualified to form a constitution and government for themselves.")

38. See BERKHOFER, supra note 33, at 259 ("A forced connection is neither our interest nor within our power."); Onuf, Statehood and Union, supra note 6, at 7.

39. After the ratification of the Constitution, the Northwest Ordinance was reenacted by Congress with minor changes. See ch. 8, 1 Stat. 50 (Aug. 7, 1789); see also ThE NoRTHWEST ORDINANCE 1787: A BICENTENNIAL HaNDBOOK, supra note 18, at xix.

40. Northwest Ordinance arts. I-V.

41. Id. at $\$ 14$.

42. Id. art. $\mathrm{V}$.

43. Ohio Enabling Act $\S 5$; Indiana Enabling Act $\S 6$; Illinois Enabling Act $\$ 4$. 
Congress was clearly not leaving to the western settlers the latitude fully to determine their new governmental forms. As one historian has put it, Congress required that the new state governments follow "eastern, not western, ideas and political structures [as] models of the future state governments." 44 "[The Ordinance] committed the United States to a colonial policy that allowed for the orderly assimilation of new territories. But . . . admission to the Union was contingent upon the adoption of a government and a society acceptable to Congress." 45 As another historian put it: "Congress was plainly unwilling to permit promiscuous emigration into the national domain or to ratify the settlers' own arrangements for government." 46 The requirements of protecting certain rights such as habeas corpus, bail, and private property were partly intended to help shape the new Northwestern states; and in turn, those governments were to shape the frontier settlers so that they would become loyal, democratic Americans. ${ }^{47}$

Of course, over time the Old Northwest would prove to be extremely loyal to the federal government. As the years went on, the types of provisions that were required by the Northwest Ordinance became commonplace in all new state constitutions. By the time Michigan was admitted in the 1830 s, Congress had abandoned any requirement for compliance with the Northwest Ordinance as a condition for admission.

\section{B. French in Louisiana}

The new Louisiana Territory was viewed with great suspicion because it was felt that the French population (a substantial portion of the territorial population) might never be loyal to the United States, that the territory might never be admitted as a self-governing state, and that it might forever remain a colony of a discrete and insular minority, not to be trusted with republican government. 48 Perhaps the strongest statement

44. Andrew R.L. Cayton, The Northwest Ordinance from the Perspective of the Frontier, in The Northwest Ordinance 1787: A BiCEnTENnIal HandBooK, supra note 18, at 1, 18.

45. Id.

46. Onuf, Territories and Statehood, supra note 6, at 1289

47. The civil rights provisions of the Ordinance were also seen as a guarantee protecting the settlers against a potentially despotic governor. Another important goal of the Ordinance, separate from the goal of providing for loyal and republican new states, was to raise money for the United States through the sale of land to new settlers in order to pay off Revolutionary War debts; the orderly and controlled settlement of the Northwest, which the Ordinance helped provide for, was essential to the success of this scheme. See BARNHART, supra note 32 , at $126-127$.

48. See, e.g., 8-1 ANNALS OF Cong. 1058 (1804)("The people, in my opinion, are at present unprepared for, and undesirous of, exercising the elective franchise."); 11-3 ANNALS OF CoNG. 533 (1811) (Rep. Quincy) (arguing that Congress could not grant statehood to Louisiana because it consists of "foreign territories" with "new habits, customs, manners and language" that if admitted risk the "infusion of a mass of foreigners into [the] Councils" of the United States); id. at 536 (Rep. Quincy stating that the citizens of Louisiana "never have been, and . . . never will be, citizens of the United States). 
was made by Rep. Quincy of Massachusetts in the debate over whether to admit Louisiana as a state: "You have no authority to throw the rights and liberties and property of this people into a 'hotch-pot' with the wild men on the Missouri nor with the mixed, though more respectable race of Anglo-Hispano-Gallo Americans, who bask on the sands, in the mouth of the Mississippi." 49 In the same debate, Rep. Gold gave as "cogent reasons against a precipitate admission of this Territory into the Union" that "the inhabitants were born under a different government, different constitution and laws; they are almost strangers to the tongue in which proceedings of this Government are to be recorded; with our Constitution, laws, and principles of jurisprudence, they have little more acquaintance than other nations." 50 And former President John Adams was quoted as saying about Louisianans that "it would be equally sensible to talk of establishing democracies among the birds, beasts and fishes." 51

As the quotes above indicate, there were several concerns about the French inhabitants of the new American territory: they were of a different ethnic background; they spoke a different language; they had a different legal and political tradition; and they were but recently subjects of Spain and France. 52 The last point was particularly worrisome to the American government, given the geographic position of lower Louisiana (abutted by Spanish Mexico and Spanish Florida) and the population's uncertain loyalty. ${ }^{53}$ Indeed, Jefferson developed a plan to colonize the new territory with American veterans from the Revolutionary War in order to provide a home-grown military force to defend the territory and guard against rebellion. ${ }^{54}$ Assimilation of Louisiana into American society was seen as essential to maintaining control over the territory. "America's hold on Lower Louisiana would never be assured 'until the territory shall be inhabited by men whose hearts are American; distinction between the

49. 11-3 ANNALS OF CONG. 538 (1811).

50. Id. at 572 .

51. Samuel B. Groner, Louisiana Law: Its Development in the First Quarter-Century of American Rule, in AN UNCOMMON EXPERIENCE: LAW AND JUDICIAL INSTITUTIONS IN LouisianA 1803-2003, at 137, 150 (Judith Kelleher Schafer \& Warren M. Billings eds. 1997).

52. Interestingly, although anti-Catholic prejudice was a contemporaneous phenomenon, with some states banning Catholics from holding public office, see, e.g., VT. Const, of 1787, chap. II, $\S$ XII (requiring representatives to be Protestant), I have found no evidence of explicit anti-Catholic rhetoric in the Congressional debates over Louisiana's admission. Of course, the discussion of Louisiana's different cultural heritage might have been a cover for religious prejudice.

53. See George Dargo, Jefferson's louisiana: Politics and the Clash of Legal. TRADITIONS 24-25 (1975).

54. Id. at 144-45. The role of immigration was seen as extremely important by the American officials in terms of assimilating Louisiana. "The hardy and adventurous sons of New England will, in a short time, compose a large proportion of the population on the waters of the Mississippi." I I-3 Annals of Cong. 569 (1811) (Rep. Poindexter) 
American and the Louisianan shall be obliterated from our laws, language and manners; ... and we become in sincerity and fact one people.""55

In the longer term, the American government's concern with Louisiana was that if it was not assimilated into American society, and its society not made more American, it would not be able to assume its role as a self-governing state within the Union, even if its loyalty could be assured through force, bribery, or apathy of the population. "At a time when differences between Virginians and New Englanders were considered formidable, ... the prospect that the United States could absorb a people whose laws and institutions were as foreign as those of the Louisianans seemed difficult if not impossible."56 Thus, the goals of securing short-term loyalty and long-term assimilation ran together. ${ }^{57}$

A large part of the anxiety about the heterogeneity of the new territory was directed not just towards the character of the people, although that was significant, 58 but in particular towards the language and the legal system, which were seen as two issues intimately bound. A great deal of the conflict between Anglo-Americans and "anciens" French Louisianans in the territory (and there was a great deal of conflict) ${ }^{59}$ revolved around the legal system that would be used in the territory and the language in which the government would function. 60 French Louisanans had been accustomed to a civil law system under both French and Spanish governments; they accepted the change to the new common law system in criminal matters relatively easily, but the question as to whether to apply the common law both procedurally and substantively in civil matters was bitterly contested. 61

Louisianans felt strongly enough about the changes being imposed

55. Dargo, supra note 52, at 153 (quoting Jeremiah Brown, A ShORT LeTter to A Member of Congress Concerning THE TERRITORY OF ORLEans 31 (Washington, D.C., 1806)).

56. Id. at 145 .

57. Id.

58. Dargo estimates that only one-seventh of the population at the time of purchase was Anglo-American, although this proportion rose through immigration. $l d$. at 10 .

59. See Dargo, supra note 52, at 23-103 (providing an overview of the history of the territorial period, including a series of conflicts between American immigrants and French Louisianans over the appointment of government officials, the disposition of submerged lands within New Orleans, and the trial of Aaron Burr for his alleged conspiracy to detach Western territories from the U.S.); see also JOSEPH G. TREGLE, LOUISIANA IN THE AGE OF JACKSON 69-114 (1999) (discussing battles in the 1820s and 1830s between "GalloAmerican" Lousianans and Anglo-American Lousianans over law, commerce in New Orleans, control of the militia, and control of the state government, including episodes that nearly led to civil war and violent ethnic conflict).

60. "The Kulturkampf between the ancienne population and the Anglo-Americans for supremacy in Lower Louisiana manifested itself most sharply as a conflict of legal traditions." Dargo, supra note 52, at 11.

61. Dargo, supra note 52, at 15-19; see also Lee Hargrave, The Louisiana State Constitution, A Reference Guide 2 (1991) (noting the fear of the common law among French-speakers). 
on them that they filed a Remonstrance in 1804 with Congress that, in part, protested against:

the sudden suspension of all those [legal] forms to which we had been accustomed; the total want of any permanent system to replace them; the introduction of a new language into the administration of justice; the perplexing necessity of using an interpreter for every communication with the officers placed over us; the involuntary errors, of necessity committed by judges uncertain by what code they are to decide, wavering between the civil and the common law ... and with the best intentions unable to expound laws of which they are ignorant, or to acquire them in a language they do not understand. 62

The Remonstrance continued with a protest against the new territorial system, in which "A Governor is to be placed over us whom we have not chosen, whom we do not even know, who may be ignorant of our language, uninformed of our institutions." 63 The Remostrance "received wide support" within Louisiana. 64

For its part, the American government saw the replacement of the foreign French and Spanish civil law system with American common law and the conversion of the governmental language from French to English as essential steps towards the assimilation of Louisiana as an American society. President Jefferson "believed in the necessity of legal uniformity as a strand in the web of national unity," as well as in the importance of common language. ${ }^{65}$ The local English-speaking community supported efforts to impose the common law, "requested that English be maintained as the official language, and called for guarantees of the rights of American settlers in the territory." 66 Numerous pamphlets and even plays over the controversy whether to use common law or civil law in the territory were written. 67

An eventual compromise between the French population (represented in the territorial legislature) and the U.S. government and its appointed governor was reached. Under the compromise, common law procedures (such as jury trials) would be used in civil cases, but the civil law remained the substantive law of Louisiana. The compromise was finalized when Governor Claiborne signed into a law a digest of Spanish and French law applicable in the territory, a digest written at the request of the

62. 8-2 American State Papers 37 Misc. No. 183, at 396 (1804).

63. Id.

64. Dargo, supra note 52 , at 18 . The ban on slave importation into the territory by Congress was another major grievance of Louisiana at the time, and was mentioned in the Remonstrance. $1 d$. at 30.

65. Id. at 107 .

66. Id. at 117 .

67. Id. at 120-124. One pampleteer wrote: "In all the other states . . a large majority of the citizens are derived from the same Nation, have adopted the same system of law, and speak the same language. These are the great bonds of the Union." Id. at 123 (quoting James Workman, Letter of LAELIUS, reprinted in MIsSISSIPPI MESSENGER, Nov. 30, 1804). 
French-dominated territorial legislature. ${ }^{68}$

The significance of the conditions imposed on Louisiana only becomes clear in the context of these cultural and legal battles in Louisiana, and the reaction of the national government. Thus, the enabling act for Louisiana emphasizes the use of habeas corpus and bail in criminal law-cementing the use of common law tools in an area (criminal law) where these tools were probably seen as most important. ${ }^{69}$ It also requires the use of English by the government, ${ }^{70}$ another tool of assimilation that was contested within Louisiana-again, Congress likely sought to ensure that the Louisiana government would not become too foreign and that the fight for assimilation would not be lost in the future. The provisions regarding civil liberties are similar to those required in the Northwest Ordinance, and would be appropriate for Congress to use when (as with the Northwest) it was generally suspicious of the abilities of the inhabitants to govern themselves in a democratic manner.

The conditions in the enabling act did not lead to significant changes in Louisiana's politics - the Americanization of the criminal law system and the government had been proceeding throughout the territorial period. However, the conditions were markers placed on the admission of Louisiana, markers of its difference from other states, and markers of the suspicion with which at least some in Congress still viewed Louisiana's admission. As a historian noted, "The fight over Louisiana's admission was a most bitter one" in large part because it was the first time that admission was to be granted "to territory not 'indigenously' American" and because "of the social-political differences in origin and history."71 The hostile quotes above were taken in large part from the debate on Louisiana's admission, and even the supporters of admission had to admit that this was a "people whose laws and usages, from time immemorial, have been materially different from those which constitute the rule of conduct in this country, and whose ignorance of our political institutions results from the very nature of the Government under which they have

68. Id. at 124, 155; see also Edward F. Haas, Louisiana's Legal Heritage: An Introduction, in Louisiana's Legal HeRITAGE, 1, 4-5 (Edward F. Haas, ed. 1983) (citing Dargo's work for the proposition that acceptance of the French civil code was a compromise by which the "ancien" population of Louisiana accepted American rule, and by which Jefferson and the American government got a less total, but faster Americanization and absorption of the territory). Thus, the Louisiana civil code, which remains unique in Amcrican law, was the quid pro quo by which the federal government was able to obtain other concessions from the French elites in Louisiana that the federal government hoped would lead, in the long run, to assimilation of the state, including common law protections for criminal law and the use of English.

69. Louisiana Enabling Act, $\S 3$.

70. Id.

71. Groner, supra note 51, at 150 
lived". 72 The enabling act eventually passed the House of Representatives by a 77 to 36 margin, indicating the substantial opposition. ${ }^{73}$ Even a few years later, some in Congress felt it necessary to explicitly single out the Louisianans for their loyalty during the Battle of New Orleans in the War of 1812 , and state that: "If suspicions had heretofore been indulged in, derogatory to the history of Louisiana, they would not longer exist."74

\section{The Civil War States and Reconstruction}

The Civil War had an enormous impact on constitutional interpretation, including the interpretation of the proper role which Congress could play in imposing conditions on states entering the Union. From 1821 (the entry of Maine and Missouri) until 1859 (the entry of Oregon) Congress only imposed conditions regarding the disposition and sale of public lands and the use of navigable rivers. Not a single condition relating to integral matters of state government was imposed on Maine, Arkansas, Michigan, Florida, Texas, Iowa, Wisconsin, California, Minnesota, or Oregon; and the only non-land related condition imposed on Missouri prevented the state from violating the privileges and immunities clause of the Constitution. 75

Two of the states that entered during the Civil War and Reconstruction period, Nevada and Nebraska, were to be subjected to additional conditions, however. In terms of the social changes required, the Reconstructed Southern states were faced with far more substantial conditions for readmission than the Northwest Ordinance states, or even Louisiana.

The conditions imposed by the Republican Congress on Nevada, Nebraska and the Southern states related exclusively to racial issues: racial equality in suffrage, in state law, and in education. They were part of the much broader conflict during and after the Civil War about the meaning of the war, about how federal-state relations had changed, and about how the status and civil rights of blacks in America had changed. The conditions were in part the result of partisan political efforts by the Republicans to ensure they would become a majority party nationwide;

72. 11-3 Annals of Cong. 557 (1811) (Rep. Poindexter)

73. 11-3 ANNALS OF CONG. 577 (1811).

74. 13-3 Ann. of Cong. 1162 (1815) (Rep. Robertson)

75. This lack of conditions probably reflects the fact that these intervening states were not perccived as being predominantly inhabited by populations different from the rest of the United States. Indeed, the only controversy that might have arisen on the admission of these states was over slavery, a controversy that was not, with the exception of Missouri, dealt with by the imposition of conditions on admission. See Don E. Fehrenbacher, The Dred ScotT Case: Its Significance in American Law \& Politics 103 (1978). Even in Kansas, which was the focus of much sectional controversy, the most significant condition was only triggered if statehood under a pro-slavery constitution was rejected, in that it prevented admission before Kansas's population reached 90,000 , or enough to obtain one representative in Congress. See id. at 479; 11 Stat. 269-72. 
yet, they also reflected a deep sense of principled ideology. And, at least with respect to the Southern states, they reflected (as with the Northwest Ordinance states and with Louisiana) a fear that the readmitted states might not be loyal and capable of self-government.

\section{Nevada and Nebraska}

Nevada was admitted in 1864, and its admission was primarily intended to bolster Republican numbers in the Senate and Congress in general. 76 The most novel condition imposed on Nevada was a requirement that the state ban slavery; ${ }^{77}$ while such a condition had been imposed through the Northwest Ordinance, no state enabling act had explicitly mentioned this requirement, and certainly after the Missouri Compromise, it was not a requirement that the South would have consented to. However, given the history of restrictions on slavery in the territories, it was not an enormously large innovation. 78

The Congressional rationale behind the restriction is unclear, given the

76. See Earl S. Pomeroy, Lincoln, the Thirteenth Amendment and the Admission of Nevada, 12 PAC. HIST. Rev. 362, 367-68 (1943). Many historians have argued that Nevada was admitted to provide votes for the ratification of the Thirteenth Amendment and/or Lincoln's reelection in 1864. See LESLIE Burns GRAY, ThE SOURCE AND THE VISION: Nevada's Role in the CIVIL WaR AMENDMENTS AND THE RECONSTRUCTION Legislation 31, 45 (1990); Russell R. Elliott, History of Nevada 83-84 (1973); Gilman M. Ostrander, Nevada: The Great Rotten Borough 1859-1964, at 35 (1966). However, given the timing of Nevada's admission, and the fact that the Thirteenth Amendment was ratified by more than enough states, such an explanation seems unlikely. See Pomeroy, Admission of Nevada, supra, at 364-67. Nonetheless, Nevada was admitted with a relatively small population, a population which rapidly dwindled after the collapse of the silver industry in the late 19th Century, giving the Nevada the unenviable title of the "rotten borough" of American states. Nevada was used as a warning by Eastern Senators opposed to the entry of states such as Arizona and New Mexico. See, e.g., 35 Cong. Rec. 5226 (May 9, 1902) (remarks of Rep. Lacey) (arguing against separate admission of Arizona and New Mexico because he was opposed to "another Nevada in the American Union, a Nevada that was admitted full of promises and hopes, and yet to-day it has only 42,000 people and they have one Congressmen and two Senators in the United States . . . . but what and whom do they represent? Area! Aridity!" and calling on Congress never to make the mistake of Nevada again). Even within a few years of Nevada's admission, it was used as a cautionary tale against the admission of other states too early. See CoNG. GLOBE 39th Cong., 2d Sess. 1363 (1866) (remarks of Sen. Conness).

77. Nevada Enabling Act $\$ 4$. Nevada was also required to adopt a constitution that was not "repugnant to the principles of the Declaration of Independence." ld. The meaning of this provision is unclear, see Michael W. Bowers, The Nevada State Constitution: A REFERENCE GUIDE, at 7, 22-23 (1993) (providing no explanation of the provision), although it was likely intended by its Republican authors to emphasize the concept that "all men are created equal" and thus the immorality and uncortstitutionality of slavery, and perhaps racial discrimination in general. See Park, supra note 6 , at 414-416.

78. Similarly, West Virginia was required to accelerate the emancipation of slaves within its borders when it was admitted in 1863. West Virginia Admission Act $\S 1$; see Joseph Howard Riggs, A Study of the Rhetorical Events in the West Virginia Statehood Movement, 17 W. VA. HIST. 191, 236-241 (1956). 
almost total lack of debate in Congress on the admission of Nevada. Given the historical context, however, including the pending ratification of the Thirteenth Amendment, the condition is not surprising. It appears to have incited almost no controversy in Nevada during Nevada's constitutional convention. ${ }^{79}$ Despite the lack of controversy, however, it was a sign of Congress's increasing willingness to use aggressive and intrusive conditions.

Nebraska, however, did not enter until 1867 , despite its enabling act also being passed in 1864 , because of its delay in accepting admission. ${ }^{80}$ In the course of the debate over whether to allow Nebraska's delayed acceptance, Congress decided to impose another condition: a requirement that Nebraska repeal a provision of its state constitution that denied suffrage to blacks. This, was the first occasion that Congress had moved to impose a suffrage requirement on a state as a condition of admission.

The purpose behind Congress's move appears to have solely been ideological consistency. The requirement was advanced by Senator Sumner of Massachusetts, a staunch supporter of black suffrage. Sumner argued that the denial of black suffrage rendered a state government not republican in form, and therefore under the Guarantee Clause, Congress had the power to require changes in the constitution. ${ }^{81}$ Radical Republicans apparently saw the Nebraska admission bill as a relatively easy way to make a symbolic statement about the importance of black suffrage to republican government, and to gain momentum in their cause for imposing black suffrage on the South (and perhaps throughout the entire country). 82 Certainly, the admission of a new Northern state with-

79. See Elliotr, History of Nevada, supra note 74, at 84-86.

80. Enabling acts were passed for both Colorado and Nebraska in 1864, at the same time that Nevada's Enabling Act was passed. Nebraska Enabling Act, 13 Stat. 47 (1864); First Colorado Enabling Act, 13 Stat. 33 (1864). However, for a variety of reasons, Colorado and Nebraska both initially chose not to form state governments. See Ellis, Colorado's First Fight for Statehood, supra note 26, at 24; Pomeroy, Admission of Nevada, supra note 74, at $364 \& 364$ n.15. The condition of a ban on slavery was imposed on both Colorado's and Nebraska's enabling acts, Nebraska Enabling Act $\S 4$; First Colorado Enabling Act $\S 4$, but by the time that Nebraska had changed its mind and agreed to accept statehood in 1865 , the Thirteenth Amendment was ratified, and the issue was moot.

81. In the context of the debate over whether to admit Colorado at the same time (1866), when Colorado had a similar ban on black suffrage, Sen. Sumner stated: "[S] uch a constitution does not comply with the requirement, that it is not republican, . . for the first principle of republican government is equality." CoNG. GlobE, 39th Cong., 2d Sess. 1329 (1866); see also Cong. Globe 39th Cong., 2d Sess. (Appendix) 57-60 (1866) (remarks of Sen. Cresswell); Lerche, supra note 6, at 589-91 ("The Nebraska debate marks the high point in Congressional use of the guarantee [clause] in the admission of new states."); WIECEK, supra note 6, at 203-205 (1972) ("Republicans hâd gone so far toward Sumner's views of the guarantee clause that they were prepared to attach a condition precedent to the admission bill forbidding the new state to discriminate on the basis of race in the matter of political rights.")

82. See CONG. Globe, 39th Cong., 2nd Sess. 456 (1866) (remarks of Rep. Banks) ("But if hereafter this question shall arise in regard to the restoration and readmission of the insurgent States, and they shall be able to affirm that the Government has no right to impose 
out black suffrage would have opened up the Radicals to charges of hypocrisy regarding the imposition of black suffrage on Southern states, even if the number of blacks in Nebraska was negligible. ${ }^{83}$

As discussed in the Introduction, what is more significant for the purposes of this paper is an element of the debate over this condition. While many Democrats objected to the claim that black suffrage was a necessary requirement for republican government, ${ }^{84}$ both moderate Republicans and Democrats also argued that conditions should not be imposed on Nebraska because, unlike the Southern states, Nebraskans had been loyal in the war and had amply shown their devotion to the Union. 85 The opponents of imposing conditions on Nebraska characterized conditions as a tool to be used where a state population could not be trusted, ${ }^{86}$ where the population was of doubtful loyalty, and where Congress was required to undertake some sort of social engineering in order to ensure that trust and loyalty would be maintained. Imposition of a stringent condition on Nebraska was seen as unfair and unnecessary by a number of Congressmen precisely because Nebraska was (in comparison to the Southern states) loyal and could be trusted.

\section{b. Reconstructed Southern States}

In contrast to Nebraska, the Southern states were naturally seen by Republicans after the Civil War as disloyal and untrustworthy. The readmission of the Southern states was attached to a number of significant conditions, including the ratification of the Fourteenth Amendment, and a requirement that the suffrage of all state citizens who had voting rights

conditions, or imposing conditions it has no power to enforce them, from the moment that doctrine is accepted the Government of the Union is at an end. It is in the hands of its enemies and will be destroyed."); see also Cong. Globe 39th Cong., 2d Sess. 130 (1866) (remarks of Sen. Sherman) ("And sir, after having passed yesterday an act which was predicated directly on the right of all men to this suffrage, with what propriety can we come in here this Friday morning and sanction by our vote that which declares those of a certain color shall be excluded from the suffrage? ... [And] with what propriety could I go back to the State of Missouri and engage them in a canvass to strike out the same clause, perhaps, from the constitution of my own state?').

83. See Cong. Globe 39th Cong., 2d Sess. 126 (1866) (remarks of Sen. Wade) (doubting that there were "not fifty" blacks in the whole Territory); id. at 167 (remarks of Sen. Cowan) (stating that "it turned out that there was only one negro" in the territory of Nebraska).

84. See, e.g., Conc. Globe 39th Cong., 2d Sess. 185 (1866) (remarks of Sen. Howard); WIECEK, supra note 6, at 204-205 (quoting Sen. Hise of Kentucky).

85. See the quotes from Senators Wade and Senator Howe in the Introduction. On another occasion, Sen. Wade said, "[N]ow all at once it is proposed to treat them as though they were rebels seeking to destroy the Union, instead of forming a most loyal and worthy part of it." Cong. Globe $39^{\text {th }}$ Cong., 2d Sess. 185 (1866)

86. See note 3, supra. 
under the Reconstruction state constitutions---which provided for black suffrage 87 -never be abridged.88 Three of the Southern states were given additional conditions: a requirement that blacks not be excluded from public office, 89 and a requirement that the states not reduce any rights blacks might have to public education under their existing Reconstruction constitutions. 90

Reconstruction was prompted by a variety of motivations, including the desire of Republicans to reshape themselves into a majority national party once the South was readmitted..$^{91}$ However, a significant motivation was also a desire to change the social structure of the South in order to create (at the very least) political equality among the races (and for some Radicals, social and economic equality as well). ${ }^{92}$ While social change was a goal in and of itself, it also was shaped in part by a belief that without such social change, the South would remain in the hands of elite, disloyal whites who would reenter Congress and undo all the years of work of Republicans during the Civil War. ${ }^{93}$ Republicans (and many

87. See note 281, supra.

88. First Reconstruction Act, ch. 153, 14 Stat. 428 (1867); An Act to admit the States of North Carolina, South Carolina, Louisiana, Georgia, Alabama and Florida to Representation in Congress, ch. 70, 15 Stat. 73. (1868); see also An Act to admit the State of Arkansas to Representation in Congress, ch. 69, 15 Stat. 72 (1868).

89. An Act to admit the State of Virginia to Representation in the Congress of the United States, ch. 10, 16 Stat. 62, 63 (1870); see also An Act to admit the State of Mississippi to Representation in the Congress of the United States, ch. 19, 16 Stat. 67, 68 (1870); An Act to admit the State of Texas to Representation in the Congress of the United States, ch. 39, 16 Stat. 80,81 (1870). This requirement was in part prompted by the Georgia legislature's (after its readmission and before the readmission of Virginia, Texas and Mississippi) exclusion of all black legislators because the state constitution did not explicitly give blacks the right to hold public office. Georgia's action led to its continued exclusion from Congress and the threat of a reimposition of military rule, until the state legislature backed down and readmitted the black legislators, as well as excluding legislators who could not pass the test oath requirements. See Alan Conway, The Reconstruction of Georgia 166-190 (1966). Congress also required Georgia to ratify the Fifteenth Amendment in order to be readmitted. See WiECEK, supra note 6, at 219.

90. See note 87 , supra.

91. See, e.g., William Gillette, Retreat from ReCOnStruction: 1869-1879, at xiii (1979).

92. See W.R. Brock, An American Crisis: Congress And Reconstruction 1865-1867 at 18 (1963) (stating that the goal of making the black a citizen "carricd Northern aims into the heart of Southern society").

93. The inclusion of test oath provisions (in which Southerners swore their allegiance to the United States and repudiation of the Confederacy in order to be able to vote) in the Reconstruction Acts is an obvious example of the Republicans' concern with loyalty. See Martin E. Mantell, Johnson, Grant, and the Politics of Reconstruction 25, 33 (1973) for a discussion of oath and loyalty requirements for office holding and suffrage in the Reconstruction process. W.R. Brock notes, however, that the alacrity with which many former Confederates took an oath of allegiance to the United States disturbed many Northerners, who believed "that the formal oath of loyalty was being taken by large numbers who remained at heart enemies of the United States." Distinguishing between loyal and 
Northerners) after the Civil War just did not trust white Southerners to be loyal Americans - for obvious reasons. ${ }^{94}$ Social and political change in the South was a way to guard against a disloyal South and make Southerners loyal Americans again in the long-run.

By cementing at least some of the political and social changes from Reconstruction in the South, Republicans saw admission conditions as a way to ensure the loyalty of the South. 95 Reconstruction of the state governments had initiated the process of social change by putting political power in the hands of loyal blacks and Unionists. However, in order to ensure that in the long-term state government would remain in the hands of the loyal blacks and Unionists, and that the political and social changes (which would require years of work) would continue, conditions would be needed to protect those initial changes, such as black suffrage, from shortterm reversal. Without admission conditions to prevent the reversal of Reconstruction policies, Republicans feared, the next election in a

disloyal Southerners was a question that "was to plague and weaken every Northern plan of Reconstruction." BROCK, supra note 90 at 15 . Brock also states that loyalty oaths were not sufficient for Republicans because "It was clear to most Republicans that this 'loyalty" would not prevent Southerners from using whatever political advantage they could win to restore Confederate leaders to power, pay the rebel debt, evade the obligations of the national debt, and to keep the negroes in a subservient condition." Id. at 269 . The oath might have been seen as having an educational and indoctrinary purpose. Senator Sumner proposed that Southerners be required to take an oath that listed the provisions of the Fourteenth Amendment, because it would "have a tendency to teach these people what we expect from them in reconstructing the South." Cong. Globe, 40th Cong., Ist Sess. 138 (1867).

94. Brock quotes Republicans as stating that "the one binding tie amongst all Republicans was a conviction 'that the destinies of the nation should never by yielded up to men whose hands and faces are dripping with the blood of murder"' $/$ d. at 45 ; see also id. at 45 (quoting another leading Republican as saying "I want to be very certain that a majority of [Southem] voters are - not merely whipped back into the Union . . . - but heartily devoted to the Union."); GilletTE, supra note 89, at 3 ("The widespread conviction in the North was tacit but clear and compelling: the South deserved to be punished and needed to be reformed because it had mounted an unjustified rebellion, had started a devastating war, and was obliged to take the consequences. Thus the war would not be truly over until the rebels had ceased being rebellious.").

General Grant, after hearing reports of violence and opposition to federal power in the South during 1866, expressed his own concerns about the loyalty of the South, and responded by closing newspapers and ordering military personnel to arrest persons charged with violence whom the civil courts were not prepared to try. MANTELL, supra notc 91, at 28.

For statements by Congressmen at the time that the Johnson provisional governments were not considered loyal, see, e.g., Cong. Globe, 39th Cong, 1 st Session, 281 (1867) (remarks of Rep. Lawrence) ('[T]he leading spirits of the rebellion, feeling the restraints of punishment removed, are defiant and insolent. Aided by the President, they have organized the form of State governments in defiance of law.")

95. See Cong. Globe, 40 th Cong., 1 $^{\text {st }}$ Sess 102 (1867) (remarks of Sen. Wilson) (characterizing the conditions as ensuring that "[t]he triumph of the power of the nation is complete; the triumph of the ideas of the nation is complete."); ConG. GlobE, $41^{\text {st }}$ Cong.. Second Sess. 2902 (June 6, 1868) (remarks of Sen. Conness) ("The only conditions that we imposed on the South were conditions which became necessary by their crimes and falsity to good faith and loyalty.") 
Reconstructed South would find the disloyal rebels in control again. The Reconstruction of the South would be ended and the changes wrought by Reconstruction undone, ${ }^{96}$ with dire results for the blacks and Unionists in the South, ${ }^{97}$ and for the country as whole.

Conditions that required black suffrage in the Reconstructed states (such as bans on discrimination, the ratification of the Fourteenth Amendment and a prohibition on changing suffrage rights granted by the Reconstruction state constitutions) were seen as particularly important because they would give the Republicans a nearly-guaranteed electoral base, which combined with white Unionists, could possibly provide a majority in many Southern states, and prevent the ex-Confederates and conservatives from regaining power. 98 Black suffrage was also seen as a key element to providing some form of political, social and economic power to blacks to protect themselves and force change on Southern society; indeed, the Republicans may have relied all too much on this tool in their process of social engineering. ${ }^{99}$ Thus, black suffrage was seen as a fundamental

96. Michael Les Benedict, A Compromise of Principle: Congressional Republicans AND RECONSTRUCTION 1863-1869, at 318 (1974). Indeed, given the hostility of many white Southemers to the substantive elements of Reconstruction and the Republican party ideology, some sort of force would be required to maintain these provisions in the South. See CONWAY, supra note 87 , at 58 ("By the beginning of 1866 Georgia had gone as far as she was prepared to go without compulsion to meet the conditions laid down for readmission to the Union.")

97. Fears for the safety of blacks at the hands of whites were probably not unfounded, given the profound hostility to the freedmen in the South. See CONWAY, supra note 87, at 61-72.

98. See Phillip S. Paludan, A Covenant with Death: The Constitution, Law, and EQUALITY IN THE CIVIL WAR ERA 100-101 (1975) ("But standing in the way of a complete reunion and the restoration of order was a South still proud of its traditions and still frightened by the potential of an unregulated population ... The obvious solution to such recalcitrance was the creation in the South of a dominant unionist element comprised of freedman. Doing so would not only provide the Republican party with political power; it would also satisfy the demands of simple justice.") (discussing the arguments of Lieber, a leading constitutional theorist of the Civil War era); see also GILletTe, supra note 89, at 2, 6 (noting that black suffrage was seen as a tool to protect the Union and ensure that loyal Republicans would retain control of the South). Indeed, many Southemers saw black suffrage primarily as an effort by the Republican party to guarantee political dominance in the South. See William ArChibald DunNing, Reconstruction: Polmtical and ECONOMiC 1865-1877, at 110-111 (1907).

For explicit statements by Congressmen that they sought to use black suffrage to guarantee loyal governments in the South, see, e.g., CONG. GloBe, 39th Cong., 2d Sess., 252 (1867) (remarks of Rep. Stevens) ("[Black suffrage] is a necessity in order to protect the loyal white men in the seceded States. The white Union men are in a great minority in each of those States. With them the blacks would act in a body; and it is believed that in each of said States, except one, the two united would form a majority, control the States, and protect themselves."); id. (arguing that black suffrage would "insure the ascendency of the Union party . . [and] on the continued ascendency of that party depends the safety of this great nation. If impartial suffrage is excluded in the rebel States then every one of them is sure to send a solid rebel representative delegation to Congress and cast a solid rebel electoral vote.")

99. See GILleTtE, supra note 89, at xiii-xiv. Radical Republicans argued that without land redistribution and black education, Reconstruction would not be successful. See HERMAN BELZ, Reconstructing the Union: Theory and Policy during the Civil. War 188-89 (1969). 
tool both to change Southern society and to protect other processes of change in the South from reversal. Later conditions such as ensuring that blacks would be eligible for public offices, and that public education would be available to blacks, can be seen as efforts to ensure that the political system was open to blacks, and that blacks would have sufficient education and understanding to effectively use their voting power. ${ }^{100}$

Not only would the imposition of conditions on the South protect and accelerate the process of change in a disloyal South - the acceptance of those conditions by the Southern states would be a statement of loyalty by those states, and a marker of their future loyalty, in contrast to their past disloyalty (of which the conditions would also be a marker). ${ }^{101}$ As a result, the Reconstruction Acts initially required a majority of registered

Proposals to "territorialize" the South and place the population and area under direct federal rule for an extended period of time were made by some Radicals during the period. Such a process would have allowed the federal govemment to impose, directly through federal law, significant and sweeping social changes on the South; such a method might have been far more effective than relying on a large minority or razor-thin majority of black voters to consistently vote together and impose their will on a hostile white elite. Admission would only have been allowed once the social changes had been effected, guaranteeing the loyalty of the South and the equality of blacks in the new society and polity. Territorialization was seriously proposed in the initial stages of the Civil War, once it became clear that the vast majority of the South was not loyal to the Union (or at least would not resist the Confederacy), and therefore that there was not a loyal population on which reconstructed states could be built once the War ended. See id. at 9-11, 19, 43-45, 50-66 (1969); see also David Donald, The Politics of Reconstruction 1863-1867, at 70 (1965) (quoting Rep. Julian of Indiana as saying that "Congress shall organize a well-appointed political purgatory located in the rebellious districts, and keep the rebels in it" for ten to twenty years during which military government would make the South safe for blacks, Unionists, and white immigrants, so that there could emerge in the South "a Christian civilization and a living democracy amid the ruins of the past')

However, such proposals were rejected, mainly because of a feeling that the Southern states had not really totally destroyed themselves. See id. at 77-81 (noting that territorialization was seen by critics as implicitly recognizing the secession by the South). Sen. Thaddeus Stevens was a leading proponent of territorialization. See Brock, supra note 90 , at 27-28 (1963) ("There is no doubt that Stevens intended the period of Territorial status to be employed to reconstruct Southern society" through disenfranchisement of the white elite, land redistribution, and education.); PALUDAN, supra note 96, at 40-42. The "territorialization" policy was used in the case of Utah; see also Part II.B.4, infra.

100. See Cong. Globe, 40 ${ }^{\text {th }}$ Cong., Ist Sess. 168 (1867) (remarks of Sen. Morton) ("I regard the education of these people as essential to reconstruction . . . and until they are educated the political power will remain almost entirely in the hands of the present rebel-educated classes.") (discussing proposal to require in Reconstruction Acts that new states provide public education); Cong. Globe, 41 st Cong., 2d Sess. 1333 (1870) (remarks of Sen. Edmunds) (stating that public education is to be required because the aristocratic tendencies of the South that led to the rebellion were based in part on the lack of education).

101. "It is not enough that [the South] should stop their hostility and are repentant. They should present fruits meet for repentance. They should furnish by their actions some evidence that the condition of loyalty and obedience is their true condition again." CoNG. Globe, 38 ${ }^{\text {th }}$ Cong., 2d Sess. 591 (1865) (remarks of Sen. Collamer) (quoted in Brock, supra note 90, at 14 (1963)); see also Cong. Globe 39th Cong., 2d Sess. 255 (1867) (remarks of Sen. Pike) ("If one of those [Southern] States should give such indication of loyalty as an adoption of this amendment would certainly be, and should accompany it by a grant of 
voters to approve the new constitution; otherwise, a simple majority of votes of cast would mean that "a loyalist minority might ratify but this would not be real evidence of loyalty in the State."102 Indeed, it was the failure of the Southern states to ratify the Fourteenth Amendment, their passage of a series of "Black Codes" to regulate freed slaves after the ratification of the Thirteenth Amendment, and the election of leading exrebels to Congress which Republicans saw as primary examples of the continued disloyalty of the South. ${ }^{103}$ These signs of disloyalty are what

suffrage to all loyal men, of whatever color, I should cheerfully vote for admission. But let them adopt it grudgingly and under protest, as Alabama did the great anti-slavery amendment, determined to give it in practice as little significance as possible, and refuse to colored citizens their rights, and I would not vote for the admission of such a State."); BELZ, supra note 97, al 229 (quoting Congressmen who considered conditions for readmission as examples of the loyalty of the Southern states); CoNwAY, supra note 87 , at 60 "[I]n the minds of some members of the [Joint Committee on Reconstruction] there seemed to be a direct correlation between loyalty to the Union and the treatment of Negroes.").

102. BROCK, supra note 90, at 206 (1963). "This was the authentic Radical conviction that Reconstruction could not be real until a majority had accepted a new concept of loyalty which included not only Union but also equality under the law." Id; see also DunNING, RECONSTRUCTION, supra note 96 , at 118 . Indeed, the requirement that a majority of voters support the new constitution was a much more stringent requirement than the "ten percent" plan proposed by Lincoln during the war, where a new government would be formed when ten percent of the 1860 voting population swore an oath of loyalty. The more stringent requirement was animated in part by the distrust of the Southerners in Congress. See BELZ, supra note 97, at 241-42. It was this distrust of Southern loyalty that helped lead Radical Republicans to refuse to readmit Lincoln's reconstructed Louisiana and Arkansas state governments. Id. at 257.

For statements in Congress as to the need for a majority of the voters to show loyalty to the United States through approval of the constitution, see CONG. GLOBE $40^{\text {th }}$ Cong., $1^{\text {st }}$ Sess. 63 (1867) (remarks of Sen. Boutwell) ("What we ask in reconstrucling these States is to secure a loyal majority."); $i d$. ("[W]e ought in the beginning to assert the doctrine that a majority of the people of these States shall assent to the work done by the conventions and show that they are ready to sustain the frame-work of government thus set up in harmony with the Constitution of the United States."); CoNG. Globe, 40' Cong., Ist Sess. 97 (1867) (remarks of Sen. Howard) ("If therefore, there be not a majority of the voting population of any one of these rebel States in favor of coming back and taking their position as a State in the Union, I am for keeping them out until doomsday, or until at least they see the error of their ways and repent in dust and ashes.") See also the remarks by Senator Howard that requiring a majority approval would make sure that the new states would be loyal. Cong. Globe, $40^{\text {th }}$ Cong., $1^{\text {st }}$ Sess. 162 (1867).

103. See 2 Bruce Ackerman, We The People: Transformations 165 (1998) (noting that the passage of the Black Codes and election of ex-Confederate generals and officers to Congress were seen as a breach of trust by the South); DUNNING, RECONSTRUCTION, supra note 96, at 44-57 (1907); JAMES WiLfORd GARNER, ReCONSTRUCTION IN MisSisSipPI, 117, 151 (1968); RichaRd Lowe, REPUBLICANS AND RECONSTRUCTION IN ViRGINIA, 1856-1870, at 3435 (1991) (noting that Republicans in Virginia felt that the appointment of ex-Confederates to the Restored Virginia government left open the possibility that the "state was to be controlled by the same men who had led it through rebellion."); id. at 51-52 (noting petitions by Republicans in Virginia in 1866 that argued that the rebels were in control of Virginia, and sought to disenfranchise recent immigrants and were hostile to Unionists); REMBERT W. Patrick, Reconstruction of the Nation 60-61 (1967); Jerrel.l. H. ShofNer, Nor Is It Over Yet: Florida IN THE ERA OF ReCONSTRUCTION 1863-1877 at 46 (1974) (noting that Sen. Sumner protested in the Senate against Florida's election of leading Confederates). 
prompted, in large part, the Reconstruction Acts of 1866. 104

Thus, when the Joint Committee on Reconstruction issued its report in favor of the Fourteenth Amendment, it phrased the importance of the Amendment as, in part, a statement of the future loyalty of the South:

It should appear affirmatively that [the Southern states] are prepared and disposed in good faith to accept the results of the war, to abandon their hostility to the government, and to live in peace and amity with the people of the loyal States, extending to all classes of citizens equal rights and privileges .... [T] hey should evince an entire repudiation of all hostility to the general government, by an acceptance of such just and reasonable conditions as that government should think the public safety demands.

... Hardly is the war closed before the people of these insurrectionary States come forward and haughtily claim, as a right, the privilege of participating at once in that government which they had for four years been fighting to overthrow ... [T]hey at once place in power leading rebels, unrepentant and unpardoned, excluding with contempt those who had manifested an attachment to the Union. 105

At the heart of the Fourteenth Amendment, and the conditions imposed through Reconstruction by the Republican Congress, was a test of

Other examples of Southern disloyalty for the North were hesitation by the constitutional conventions of 1865 (convened by Johnson's Reconstructed governments) in repudiating Confederate debts, repudiating secession, and accepting the Thirteenth Amendment, as well as attempts at compensation for the emancipation of slaves. See PALUDAN, supra note 97, at 214-215 (" $[1] \mathrm{t}$ is most likely that the South could have satisfied northern opinion by ratifying the Thirteenth Amendment, repudiating secession, and acquiscing in the exercise by blacks of civil, but not political rights. It did the first reluctantly, the second with infuriating equivocation, and the third not at all ... All these things served to convince the North that there was practically no white loyalty in Dixie. The obvious recourse was to counterbalance white disloyalty with the loyalty which the freedmen would offer."); see also ConwaY, supra note at 87, at 45-57; Harold H. Hyman, A More Perfect Union: The Impact of the Civil WAR AND ReCONSTRUCTION ON THE CONSTITUTION, 429 (1973).

104. See DAVID DONALd, supra note 97, at 57 (arguing that the rejection of the Fourteenth Amendment by Southern legislatures prompted the passage of the Reconstruction Acts). Later resistance by Southerners to the conditions for readmission under Reconstruction prompted additional anger on the part of Radicals. Thus, according to Paludan, the Radical constitutional theorist Francis Lieber reacted strongly to Southern resistance: "When southern states did not immediately yield to congressional conditions of readmission, the angry author suggested that one or two of the recalcitrant states be territorialized as examples to the others." PALUDAN, supra note 97, at 102-103; see also PATRICK, supra note 101, at 90 (stating that the both ratification of the Fourteenth Amendment and providing black suffrage were considered as important symbols of Southern loyalty)

105. Report of the Joint Committee on Reconstruction, 90. The Report provided extensive evidence of violence towards blacks and Unionists, and evidence of the continuing disloyalty of the South. See Brock, supra note 90, at 124; PATRICK, supra note 101, at 80-81. Even a sympathetic Southern historian, who argued that the South was truly loyal after the Civil War, and that little more than the South had already conceded could be expected from a defeated people, admitted that the Radical Republicans belicved the South was still disloyal. GARner, supra note 101, at 148-156; see also DunNing, ReCOnstruction, supra note 96 at 66 . Ackerman describes this report as "demanding nothing less than a spiritual transformation of the South." 2 ACKERMAN, supra note 101, at 175; see also Brock, supra note 90, at 103 (stating that Sen. Sumner associated "the idea of loyalty with acceptance of the plan for negro suffrage"). 
political loyalty: "Were you loyal to the Union or were you a traitor?"'06 The South was required to meet that test, through explicit agreement to black suffrage and ratification of the Fourteenth Amendment, before it was to be readmitted to the Union. ${ }^{107}$

\section{Mormons of Utah}

Another great crusade of Republicans in the $19^{\text {th }}$ Century was the elimination of polygamy and the secular power of the Mormon church in Utah. ${ }^{108}$ Because Utah had not yet become a state, Congress could leave it as a territory, with strict federal control over its internal affairs, until it had changed its ways. The imposition of the condition of a perpetual prohibition of polygamy on Utah was part of a much larger struggle for the "Americanization" of Utah before it would be admitted as a state. 109

The Mormons had moved to Utah to escape what they perceived as persecution by their Gentile (non-Mormon) neighbors in Illinois, Missouri and lowa (among other locations). 110 By the 1850s, the Mormons had established a thriving colony in Utah, a colony almost totally isolated from the rest of the United States, almost uniformly Mormon, and one where the practice of polygamy flourished openly. ${ }^{111}$ In the late $1850 \mathrm{~s}$, President Buchanan sent a large number of federal troops to suppress an alleged Mormon insurrection; bloodshed was averted only because the newly appointed federal governor for Utah was able to reach a compromise with the Mormon leader Brigham Young. 112

106. 2 ACKERMAN, supra note 101, at 181. Another historian wrote: "The restoration of the Southern States was not enough without a reconstruction of Southern minds." BROCK, supra note 90 , at 14.

107. The states of Virginia, Texas and Mississippi, which were readmitted at a later date, werc forced to consent to additional conditions, including guaranteeing that blacks would be eligible for public office and that education would be available to blacks. See note 87, supra. These provisions were imposed, in part, because the new state governments were perceived as "disloyal," as conservatives had already won elections in those states. See DunNing, RECONSTRUCTION, supra note 96, at 180.

108. In the 1850s, the Republicans stated in their campaign rhetoric that their primary position was that Congress had the right "to prohibit in the Territories those twin relics of barbarism - Polygamy and Slavery." DEAN L. MAY, UTAH: A PEOPLE's HiSTORY 96 (1987).

109. The title of a leading history of Utah's statehood movement is "The 'Americanization' of Utah for Statehood." Gustave O. LARSON, THE "AMERICANIZATion" of UTAH For STATEhood (1971). A chapter in another Utah history book is titled "The Americanization of Utah." See MAY, supra note 106.

110. See MAY, supra note 106, at 44-48 (1987).

111. Id. Chap. 4 \& 5; see also Sarah Barringer Gordon, The Mormon Question 27, 58-60 (2002); Jean Bickmore White, The Utah State Constitution: A Reference Guide 1, 3-4 (1998) (noting that Mormons wanted to found a separate society, and that the Mormon church dominated Utah politics and economics in the 1850s).

112. MAY, supra note 106, at 96-99. 
After the Civil War, Mormon polygamy, and other aspects of Mormonism, received more and more attention from the broader American public. Public pressure, particularly from Eastern Protestant churches, grew for federal officials to eliminate what Easterners perceived to be the barbaric practice of polygamy from Utah; these churches also objected to what they saw as the hierarchical nature of the Mormon church, and its deep involvement in politics.113 A growing Gentile population in Utah 114 also complained about the perceived suffocating hold the Mormon church had on the political, economic, and social life of the territory, as well as the practice of polygamy. 115

Polygamy was certainly the aspect of Mormon society that received the most attention as setting Mormons apart from the rest of America. Polygany had begun in Mormon society in the 1840 s, but was made public in 1852 by the church, and became relatively widespread in Mormon society by the 1860 s and 1870 s. One historian estimates that ten percent of married men in Kanab, Utah were in polygamous marriages, with 25 percent of all residents in polygamous households. 116

But while polygamy was a lightning rod for the critics of the Mormon church within and outside the territory, the critics had other concerns besides plural marriage. The critics also saw Mormonism as a threat to American democracy and to the separation of church and state. 117 The Mormons before the 1890s developed policy positions within the church, and once a decision had been reached, the membership was bound to vote the church position; "[ $t]$ he voting was a symbol of commitment to a consensus already reached, not a means of making decisions."118 Mormons therefore generally voted together in a large bloc for candidates endorsed by the church, which meant that non-Mormons effectively had no voice in

113. Id. at 123 (stating that Protestant churches "quite honestly saw Mormonism as a heresy" with a "hierarchical system of church government [which] they saw as a form of Oriental despotism, using any means, including terror if need by, to keep the rank and file ignorant, superstitious, and hence responsive to the will of the leaders"); see also Gordon, supra note 109, at 33-35, 69-70, 77-78, 93-96.

114. The Gentile population began growing with the arrival of the transcontinental railroad and an extensive mining industry (generally controlled and run by Gentiles). MAY, supra note 106, 113.119; Ken Verdoia \& Richard Firmage, Utah: The Struggle for STATEHOOD 97-108 (1996).

115. MAY, supra note 106 , at 123.

116. MAY, supra note 106 , at 125.

117. See H.R. REP. No. 50-4156, at 13 (1889) (minority report opposing proposal for statehood for Utah) (stating that Congress should not admit the state until it is "satisfied that within said Territory there is no union of church and State"); id. at 15 ("the first and insurmountable objection is against the theocratic form of church government prevailing") and generally throughout the minority report; see also White, The Utah State Constrtution, supra note 109 , at 6 .

118. MAY, supra note 106 , at 124. 
the territorial government. ${ }^{19}$ As a result, elections in the Utah Territory before the federal government intervened often involved only one, church-endorsed candidate for each office. 120 Once elected, officials closely consulted with and followed church leaders' advice. ${ }^{121}$ Showing the depth of feeling that bloc voting provoked, one historian characterized this as "utterly alien to the American way of doing things" at the time, where rowdy and hotly contested political campaigns between parties were expected (even if not realized in reality, especially in the South). ${ }^{122}$ Mormons who disagreed with the church position on political, social, or economic matters and expressed that dissent publicly were excommunicated and ostracized from the community. ${ }^{123}$ Moreover, the goal of Mormon politics (at least as characterized in sermons) was the eventual replacement of all secular governments throughout the world with the "Kingdom of God" which would "one day roll forth to fill the whole earth and subdue all kingdoms." 124 The Civil War was described by Mormon leaders as the beginning of the end for the United States government, which would be replaced by the Mormon theocracy. ${ }^{125}$ Outside critics, based on these statements, raised fears that the Mormons were less than loyal to the United States government - threats by the Mormons to secede

119. Id. at 123 ("[T]he Mormon majority was so self-contained that it often ran roughshod over [Gentile] minorities, leaving them disenfranchised and without an effective voice in local politics.")

120. Id. at 124; see also VerdoIA \& FIRMAGE, supra note 112, at 105-106 (noting that non-Mormon residents and federal territorial officials complained "about the church's political monopoly and control of government"); EDWARd Leo Lyman, POLTICAL Deliverance: The MORMOn Quest for UTAh STATEhOOD 13 (1986) ("Citizens of the Kingdom of God . . exercised their freedom through sustaining the decisions of their ecclesiastical leaders and voting unanimously for the candidates selected by them."). Most elected officials in early Utah history were also church officials. See LARSON, supra note 107, at 3-5 (quoting a survey report by a federal official that the temporal government "is so intimately blended with the spiritual administration of the church, that it would be impossible to separate the one from the other .... This intimate connection of church and state seems to pervade every thing that is done. The supreme power in both being lodged in the hands of the same individuals. ...").

121. MAY, supra note 106 , at 124.

122. Id. at 124 .

123. For example the Godbeites were a faction of Mormons who advocated "political, social, and economic diversity, free enterprise, and a more full and complete social and economic integration with the rest of the country." Their activities, including publishing a newspaper, led to the excommunication of the Godbeite leaders in 1869. Verdola \& FIRMAGE, supra note 112, at 93-95 (1996).

124. MAY, supra note 106, at 124; LARSON, supra note 107 , at 1 .

125. MAY, supra note 106, at 124-25; LARSON, supra note 107, at 29 (quoting Mormon leader Brigham Young's address to the shadow state government in 1863: "We are called the State Legislature, but when the time comes, we shall be called the Kingdom of God. Our government is going to pieces and it will be like water that is spilt upon the ground that cannot be gathered ... . But I do not want you to lose any part of this Government which you have organized. For the time will come when we will give laws to the nations of the earth."). 
in the 1850 s exacerbated the distrust. ${ }^{126}$ Critics also pointed to stories circulating that Mormons were required to take oaths of loyalty to their church that superceded their loyalty to the Union. ${ }^{127}$

By the 1870 s and 1880 s, Utah territorial politics was divided into two political parties unique to Utah: the Liberal Party, always in the minority, supported by Gentiles, which sought to limit the power of the Mormon church; and the People's Party, essentially the political arm of the Mormon church, which was by far the dominant political power, and which won almost all the territorial elections. ${ }^{128}$ Thus, in the $1870 \mathrm{~s}$ and 1880 s, many Gentiles in Utah "felt [they were] not being represented in a democratic fashion in the territorial legislature and that some action was needed to bring democracy to Utah." 129

Critics also were threatened by the large numbers of European immigrants that the Mormons brought to Utah. These critics characterized immigrants as uneducated, lower-class foreigners who had been duped into following a despotic and hierarchical church. ${ }^{130}$ Thus, the fear of Mormons as un-American was connected with ethnicity as well.

Education was another point of conflict between Mormons and nonMormons in Utah. Mormons from the 1850 s until the 1890 s had generally refused to support or attend the public school system in Utah, because of concerns that a secular, territorial public school system would lead to nonMormon control of the education system; instead they attended their own church-based schools. ${ }^{131}$ Gentiles in Utah responded by creating their own denominational school system, partly in hopes that they might encourage Mormon children to attend and then convert those children to more "traditional" denominations. 132

126. LARSON, supra note 107, at 19-20.

127. LARSON, supra note 107, at 84-86.

128. VerdoIA \& FiRMAGE, supra note 112, at 129 (1996); LYMAN, supra note 118, at 14$15,19$.

129. MAY, supra note 106, at 125; see also LARSON, supra note 107 , at 102 (quoting from a 1882 petition of Gentiles in Utah, primarily criticizing the Mormon church for "exalt[ing] the Church above the State," for "destroy[ing] the freedom of the citizen by assuming the right to dictate his political action and control his ballot" and which concluded by calling for direct rule of the territory by Washington).

130. See Verdola \& FIRMAGE, supra note 112, at 98; see also GoRdon, supra note 109, at 192-94. "Not an inconsiderable part of the inhabitants of [Utah] are the dregs of European governments, gathered in hordes by the Mormon missionaries in Europe." 26 ConG. REC. 175 (1893) (remarks of Rep. Morse).

131. See MAY, supra note 106, at 118; see also H.R. REP. No. 50-4156, at 222-29 (1889) (minority report that opposes admission of Utah reprinting report from Utah Territory Schools Commissioner that the territorial legislature had refused to provide funds to one public school system unless private schools were also supported by tax receipts).

132. See MAY, supra note 106, at 119-20; see also Gordon, supra note 109, at 198-200 (describing critics charging that Mormons resisted public education to keep church members ignorant and docile). 
Mormon economic cooperative efforts, such as church-owned department stores, railroads, and other businesses, also prompted charges of un-American, anti-capitalist activities. 133 The Mormon church throughout the mid- and late-19th Century emphasized its economic independence from Gentile society, and was accused by its critics of boycotting and attempting to destroy Gentile businesses in Utah. ${ }^{134}$

Thus, social relations (through polygamy), political relations (through consensus religious government), and economic relations all combined to make Mormon society in Utah in the mid to late $19^{\text {th }}$ Century distinctively different from American society as a whole. Mormons were different because of far more than just polygamy. ${ }^{135}$ As a result, Gentiles in Utah "vigorously opposed statehood," for a variety of reasons "reminding Washington officials on every possible occasion of the un-American Mormon practices of cooperative economic development, consensus politics, and polygamy." 136

The distinct nature of Mormon society led to strong language in Congress calling the Mormons "un-American," disloyal, and un-Christian. In discussing a bill to suppress polygamy in Utah, a Congressional committee said: "The Mormon system is directly antagonistic to all ideas of European and American civilization." 137 Another Congressional committee discussing anti-polygamy legislation in the 1860 s stated that the Mormons believed "that the government of the United States will not and ought not to stand," and called Mormonism a "Jewish theocracy."138 Another report in the 1860 s stated that polygamy was "one of the highest crimes against society by the common consent of all Christian nations."139

Given the unpopularity of Mormonism in the United States, ${ }^{140}$

133. May, supra note 106. at 125; see also GoRdon, supra note 109, at 195-96.

134. See VERDOLA \& FIRMAGE, supra note 112, at 104-105.

135. See also Carol Weisbrod, The Boundaries of Utopia 17-33 (1980) (discussing the economic, social, and political aspects of the Mormon community that made them different from the rest of late $19^{\text {th }}$ Century America, and arguing that "Mormonism was perceived as antithetical to and subversive of American ideals and values," and that it was the large scale of Mormonism as a successful religious, social, and political unit that made it a threat to the federal government and the rest of American society, and therefore prompted federal action to control Mormonism though the banning of polygamy, redistribution of church property, and the disenfranchisement of Mormons).

136. MAY, supra note 106 , at 123.

137. H.R. REP. No. $49-2735$, at 3 (1886).

138. SEN. ReP. No. 37-87, at 2 (1863).

139. H.R. REP. No. 39-27, at 2 (1867); see also H.R. REP. No. 50-4156 (minority report), generally for extensive discussion of the perception of the Mormons as un-American, disloyal and untrustworthy.

140. One historian refers to "[a]n anti-Mormon frenzy [that] was being fed by the national press of the day.... Their accounts of the evils of polygamy and church control of politics were lurid, shocking, and almost routinely told from an anti-Mormon perspective." VERDOIA \& Firmage, supra note 112 , at 122. Another historian describes popular sentiment at the 
statehood and self-government appeared to be out of the question for Utah. Despite repeated petitions for statehood by Utah, territorial government was continued.141 Opponents of statehood argued that, if given full self-government, the Mormon church would completely control the state government, protect polygamy, ${ }^{142}$ and oppress its political and religious opponents.

Moreover, the plenary power of Congress over the territories meant that Congress could use legislation to suppress polygamy and even the Mormon church itself. The first anti-polygamy law for the territories, the Morrill Act, was passed by Congress in 1862, although the exigencies of the Civil War led President Lincoln not to enforce the law against the Mormons. ${ }^{143}$ However, a petition for statehood by the Mormons in the late 1860 s that reminded Congress of the unenforced polygamy laws (and actually proposed the repeal of those laws) ${ }^{144}$ stirred Congress to action. A harsh anti-polygamy bill was defeated in 1870 , but a series of later laws led an all-out assault on the Mormon church. The Poland Act of 1874 transferred jurisdiction of criminal cases (including polygamy cases) to federal district courts from local probate courts, which had been run by locally-elected Mormon judges. ${ }^{145}$ After the U.S. Supreme Court upheld the anti-polygamy laws in U.S. v. Reynolds, ${ }^{146}$ Congress moved

time as seeing polygamy as "licentious, immoral, and degrading" and states that "[f]or three decades letters and petitions poured into the nation's capital from women's groups, clergymen, editors, religious organizations and federal appointees. . . . [T] he persistence of plural marriage under local political protection brought demands for legislation to crush Mormon theocracy through" invasion by federal troops, partition of Utah, Gentile immigration to Utah, or direct federal rule. LARSON, supra note 107 , at 52.

141. "With 90,000 residents and an extensive settlement and governing structure, Utah in 1870 was far ahead of many territories then being considered for admission to the Union. However, another constitution and petition for statehood were greeted with icy silence by President Grant and by Congress." VeRDOIA \& FIRMAGE, supra note 112, at 109. In 1890, Utah had over 200,000 residents, was "the most qualified of all the handful of territories seeking admission to the Union," and had the largest population of any territory in the United States, but it was still not admitted, while in a period of eight months in 1889 to 1890 Washington, Montana, Idaho, Wyoming, North Dakota and South Dakota would all be admitted.

142. Such beliefs may not have been entirely unwarranted. The proposed 1889 Utah Constitution outlawed polygamy, but Mormon lcaders noted in private that the provisions did not prohibit cohabitation, but simply multiple civil marriages, and that therefore polygamy would be able to continue. See Stanley S. Ivins, A Constitution for Utah, 25 UTAH HisT. Q. 95, 99 (1957).

143. MAY, supra note 106, at 125 . An apocryphal quote attributed to Lincoln at the time explained why he chose to not enforce the law. He made an analogy to life on a farm, where farmers come across logs in the field that are "too hard to split, too wet to burn and too heavy to move, so we plowed around it. That's what I intend to do with the Mormons." Id. at 123 .

144. H.R. REP, No. 39-27 (1867).

145. MAY, supra note 106 , at 126. Pomeroy, supra note 19 , at 58-59, notes that Utah had purposefully created and expanded the jurisdiction of the probate courts to limit as much as possible the power of the federal courts.

146. 98 U.S. 145 (1879). 
aggressively. The Edmunds Act of 1882 made polygamous marriages a felony, and cohabitation with polygamous wives a misdemeanor. ${ }^{147}$ Moreover, the Act moved to eliminate the political power of the Mormon church; an election commission (the Utah Commission) was established to oversee election procedures in the state. ${ }^{148}$ Federal officials began to aggressively enforce the polygamy statutes against the leaders of the Mormon church, who were either imprisoned or forced into hiding. 149

However, just as the criticism of the Mormon church and Mormon society as un-American was not limited to the practice of polygamy, but also included its broader political and economic power, so too Congress's legislative actions were extended more broadly to attack the Mormon church as an institution. The Edmunds-Tucker Act of 1887 was "designed to destroy the Mormon church economically and politically."150 It authorized the Utah Commission to implement a test oath that would effectively bar polygamists (and potentially all Mormons) from voting by requiring all voters, jury members, and officeholders to affirm obedience to and support of the anti-polygamy laws; it disincorporated the Mormon church and provided that almost all of its property was to be forfeited to the United States; and it eliminated women's suffrage, a key to Mormon power since the vast majority of women in the territory were Mormon.151 Shortly afterwards, a bill was introduced into Congress to strip all Mormons of their suffrage rights; the bill was modeled after a similar provision used by Idaho and upheld by the Supreme Court. ${ }^{152}$

147. Act of Mar. 22, 1882, ch. 47, 22 Stat. 30 (1882). See LyMAN, supra note 118 , at 22 23 and LARSON, supra note 107 , at 95 , for a discussion of the Act in detail.

148. "The object of the bill is to take the political power in the territory out of the hands of this body of tyrants." VerdoIA \& FIRMAGE, supra note 112, at 125 (quoting Sen. George F. Edmunds, sponsor of the Edmunds bill). In its first year of existence, the Commission disenfranchised over 12,000 Mormons. Id. at 127.

149. MAY, supra note 106, at 126; VerDoIA \& FIRMAGE, supra note 112, at 129-135. A "Mormon underground" was even created to help shicld suspected polygamists from federal marshals. Id. at 131; see also LYMAN, supra note 118, at 24-25.

150. MAY, supra note 106, at 127 ; see also VeRDOIA \& FIRMAGE, supra note 112, at 137 140.

151. LARSON, supra note 107, at 210-212; MAY, supra note 106, at 127; VERDOIA \& FIRMAGE, supra note 112 , at 137-140.

152. MAY, supra note 106 , at 128. The Idaho Test Oath provided that "[n]o person is permitted to vote, serve as a juror, or hold any civil office . . . who is a bigamist or polygamist, or is living in what is known as patriarchal, plural, or celestial marriage, or in violation of any law of this State, or of the United States, forbidding any such crime; or who in any manner teaches, advises, counsels, aids, or encourages any person to enter into bigamy, polygamy, or such patriarchal, plural, or celestial marriage, or to live in violation of any such law or to commit any such crime; or who is a member of or contributes to the support, aid, or encouragement of any order, organization, association, corporation, or society which teaches, advises, counsels, encourages, or aids any person to enter into bigamy, polygamy, or such patriarchal or plural marriages, or which teaches or advises that the laws of this State prescribing rules of civil conduct are not the supreme law of the States." IDAHo CoNST. Art. VI, 
In the face of the overwhelming pressure, Mormon Church President Wilford Woodruff issued a Manifesto in which the church advised its members "to refrain from contracting any marriage forbidden by the laws of the land."153 The Mormon church also moved to disband the People's Party, and to encourage its members to join, in more or less equal amounts, newly formed Democratic and Republican parties in the territory. 154 Thus, the Mormon church did not just capitulate by surrendering polygamy, but it also moved to reduce its overt political influence in the territory as well. Over the next few years, the federal government pardoned polygamists, restored property to the Mormon church, and resistance throughout the U.S. towards statehood for Utah lessened considerably. ${ }^{155}$ In 1896, the Utah Enabling Act was passed. 156

The Enabling Act established a fundamental condition that "polygamous or plural marriages are forever prohibited," 157 and it also required that Utah provide a public school system "free from sectarian control." 158

$\S 3(1890)$, reprinted in H.R. REP. No. 51-1064, at 6 (1890); see also Davis v. Beason 133 US 333 (1890) (upholding the use of the Idaho Test Oath). Even more extensive social engineering was proposed by the Utah Commission in 1889 , including federal control of a public school system, eliminating all elected territorial officer positions, and a ban on Mormon immigration to Utah. VERDOLA \& FIRMAGE, supra note 112 , at 147.

153. LYMAN, supra note 118, at 132; MAY, supra note 106, at 128; VERDOIA \& FIRMAGE, supra note 112, at 157-160.

154. MAY, supra note 106, at 128; see also Verdola \& Firmage, supra note 112, at 160 162 ('The Mormon church quickly set about disbanding its political People's party, and it actively encouraged its members to join either the national Democratic or Republican parties. In fact, church leaders had to strongly encourage Mormons to consider membership in the Republican party, given its history of tough anti-Mormon stances.").

155. MAY, supra note 106, at 128-130; VERDOIA \& FIRMAGE, supra note 112, at 163-172.

156. The dramatic change in political opinion towards Utah is shown by the fact that there were only two dissenting votes in the Senate for the Enabling Act. Verdoia \& FIRMAGE, supra note 112 , at 172 .

157. Utah Enabling Act $\S 3$.

158. Utah Enabling Act $\S 3$. The restriction on sectarian public schools was first imposed on the states created in 1889 (the Omnibus States, Montana, Washington, North Dakota, South Dakota). Beginning with those states in 1889 , and continuing through the admission of Arizona and New Mexico in 1912, Congress required new states that were to receive lands from the federal government for a school system to provide for "the establishment and maintenance of a system of public schools, which shall be open to all children . . . and free from sectarian control." Omnibus Enabling Act $\$ 4$. The provision was only first incorporated into proposed Enabling Acts for new states in 1888, despite the numerous (unsuccessful) proposals for admission by a number of Western states in the 1880 s. Utter \& Larson, supra note 6 , at 458-461. The provision was hardly mentioned in the debates on the Omnibus Enabling Act in 1888, except by Senator Blair, who connected the condition to a constitutional amendment that he had proposed, and which was identical to the Blaine Amendment defeated in 1875. See id. at 461-62; see also Frank J. Conlin \& James M Vaché, The Establishment Clause and the Free Exercise Clause of the Washington Constitution - A Proposal to the Supreme Court, 8 U. Puget SOUnD L. REV. 411, 436-442 (1985). The Blaine Amendment was intended to cut off all public funding to sectarian and denominational schools - which at the time, meant Catholic parochial schools. See Steven K. Green, The Blaine Amendment Reconsidered, 36 AM. J. LEG. HIST. 38 (1992); F. William O'Brien, 
The Enabling Act says nothing about the political power of the church. Still, the history of relations between the federal government and the Mormon Church in Utah, as well as the rhetoric and language used by the critics of the Mormon Church in Congress, makes it clear that the issue of polygamy and the political power of the Mormon Church were connected in the minds of many Congressmen and other American leaders. 159 "The

The Blaine Amendment 1875-1876, 41 U. DeTRoIT L. J. 138, 138-150 (1963); Utter \& Larson, supra note 6, at 464-67. The Amendment was prompted by nativist fears of Catholic immigration, and by a Protestant reaction to Catholic atlempts to obtain public funding for their parochial schools and to remove Protestant influences from the public school system (at a time when most public schools used the Protestant Bible and sang Protestant hymns). See Green, The Blaine Amendment, supra; O'Brien, supra, at 138-150; Utter \& Larson, supra note 6, at 464-67. After the Amendment had come close to success in 1876 and its sponsor had left Congress, Senator Blair introduced the Amendment unsuccessfully a number of times. See Utter \& Larson, supra note 6, at 464 . However, Blair was successful in introducing the concept of the Blaine Amendment into the Enabling Acts for the Omnibus States; the condition was then repeated in the Enabling Acts for a number of states, including Utah, Arizona and New Mexico. See Conklin \& Vaché, supra, at 433, 436. The restriction was incorporated in a number of places in the Omnibus Enabling Act, both in Section Four, where it operated as a general restriction on the state's funding of public schools, and in Section Seventeen, where it was a condition of the land grants made to the states for public schools. See Omnibus Enabling Act $\$ \S 4,17$. I have found no evidence in the Congressional debates or hearings over the admission of Utah or New Mexico that later Congresses were aware of the original motivation behind this provision, or that Congress intended to use the condition to attack the Mormon school system in Utah or the Catholic school system in New Mexico. Indeed, the later debates and hearings on the admission of Utah, Arizona, and New Mexico do not discuss the provision at all. However, given the origins of the provision, and the fact that it has in fact been relied upon in the courts as partial grounds for the elimination of public funding of Catholic schools in New Mexico, see notes 266-268 infra, and accompanying text, this provision might have received the tacit support of those who were already hostile to Mormons and Catholics in the West and felt they were a threat to American society. And, in 1888 and 1889 , when the condition was first proposed, Mormonism was seen as a threat throughout the West, not just in Utah, and therefore Congressmen might have seen the amendment not only as a suitable means of attacking Catholic parochial schools, but also a means of preventing the spread of publicly-funded Mormon schools. Thus, the House Committee on the Territories in 1887 reported a proposed Enabling Act for Montana Territory which would have required the state to prohibit polygamy in its constitution, a response to the threat of polygamous Mormons settling in and controlling the state. H.R. REP. No. 49-3689, at 9 (1887). Conklin and Vaché, supra at 424-442, drew similar conclusions from the historical context of these provisions. See id. at 460 (" $[\mathrm{H}]$ istorical evidence suggests that conditions were extracted to promote anti-Catholic and anti-Mormon ideology.").

Such a provision, in the context of Utah's admission, might be explained as an attempt to break the power of the Mormon church over education; during the 1870s and 1880s, one of the calls for reform by the Gentile minority in Utah was for the creation of a secular, publicly-funded public school system to assimilate the Mormon children into American society and to eliminate the power of the church. See, e.g, MAY, supra note 106, at 118-119 (describing the conflict between Mormons, who sought to educate their children in their own church schools, and the Gentiles, who sought to use the public school system as a way to assimilate the Mormons).

159. Thus, when the territorial chief justice began a trial against Mormon leader Brigham Young for polygamy, he said: "While the case at bar is called The People versus Brigham Young, its other and real title is called the People versus Polygamic Theocracy." VerdoIA \& FiRMAGE, supra note 112 , at 112 (1996). In rejecting a petition for statehood in 1887 , the Senate passed a resolution stating: "It is the sense of the Senate that the Territory of Utah 
moral issue [of polygamy] served as a convenient battle cry ... for political leaders in Washington bent on 'Americanizing' the Mormon community in preparation for statehood." 160 In short, without the renouncement of political power by the Mormon church and the abolition of the People's Party, Utah statehood would not have been achieved. 161

In part the issue of statehood for Utah was a question of whether Mormon society, with its distinctive social, economic, and political features, would be acceptable as a self-governing unit within the United States. 162 Mormonism, apparently, was just too different from the rest of the U.S., too distinctive a society, to be given self-government. Until the most prominent features of that distinctiveness were surrendered by the Mormons-in particular, polygamy and a political party that was closely attached to a dominant church - Utah would not receive statehood.

The issue of polygamy and Mormon political power could also be seen as an issue of trust and loyalty; as one anti-Mormon advocate wrote in 1869: "[I]t is time to understand whether the authority of the nation or

ought not be admitted until it is certain beyond a doubt that the practice of plural marriages, bigamy and polygamy has been entirely abandoned by the inhabitants of said Territory, and until it is likewise certain that the civil affairs of the Territory are not controlled by the pricsthood of the Mormon Church." VERDOIA \& FIRMAGE, supra note 112, at 143 (citing 19 CONG. REC. 2391 (1888)); see also H.R. REP. No. 50-4156, (stating that Utah has been denied statehood because of "reasons going directly to church government and polity; the alleged practice of crimes by many of the Mormon people under sanction of the church; the maintenance of a theocracy in the administration of church affairs; the union of church and state, and the rebellion against and defiance of the laws of the United States."); S. George Ellsworth, Introduction, in UTAH's ROAD TO STATEHOOD 5, 8 (Branford R. Cole \& Kenneth R. Williams, eds., 1995) (noting that the Mormon church had to renounce polygamy, its economic power, and its political power through the dissolution of the People's Party in order to obtain statehood); LARSON, supra note 107, at 301 ("[S]tatehood had been witheld from the Mormon territory until 'true democracy' should be established, which required separation of church and state in government, and conformity with American standards in such areas as judicial procedures, marriage relations, public education and economic practices."); GORDON, supra note 109, at 69, 91-92, 128-29, 140-41, 143-44, 150, 153, 180. But see LYMAN, supra note 118, at 231 (stating that the key factor for Utah statehood "was the seemingly altered course of the Latter-day Saints regarding plural marriage.").

160. LARSON, supra note 107, at 62; see also id. at 243 (quoting a Gentile historian as writing that polygamy was only a "good war cry" and that the true objection to Mormons was their "unity; [their] political and commercial solidarity; the obedience [they] render [their] spiritual leaders in temporal affairs. We want [them] to throw off the yoke of the Priesthood, to do as we do, and be Americans in deed as well as in name"); id. at 245 (quoting Utah Territorial Governor West in 1888 as saying that statehood would not be granted until the political power of the Mormon Church was broken).

161. LARSON, supra note 107, at 283; see also HowARD RoBERTs LAMAR, THE FAR SOUTHWEST 1846-1912: A TerRITORIAL HISTORY 377-78 (1970) (noting that Mormon resistance to two-party political system and secular government were among the main factors that made Mormons seem different).

162. See Jean Bickmore White, Charter for Statehood: The Story of Utah's Constitution 16, 17-18 (1996) 
the authority of Brigham Young is the supreme power in Utah." 163 Critics of the Mormon church saw it as a potentially disloyal body that could not be trusted with control over a state government. 164 One witness testifying before Congress in 1889, and quoted by the (successful) opponents of statehood in that year stated: "Polygamy is not dead. It is but sleeping. You clothe Utah with statehood and it will be entrenched more strongly than before. The time will come when there will not be a Gentile in the Utah legislature."165 Another critic in 1889 was quoted by Congressional opponents: "[T]here can be no assurance that the powers of a State government, if conceded, would not be perverted and abused by unfriendly and proscriptive legislation, and by an equally vicious administration, to the extent of driving the hopeless minority from the State." 166

The Mormons also phrased the debate in the manner of trust. In a petition for statehood in 1872 , the Utah territorial legislature asked Congress what pledges with regards to plural marriage would be required to obtain statehood, and promised to fulfill those pledges, provided a majority of voters agreed. ${ }^{167}$ In the proposed constitution of 1887 , the delegates provided for the prohibition of polygamy and made the prohibition in the constitution unamendable without the consent of Congress and the President. "The convention was attempting to convince everyone concerned of the sincerity of its abjuration of polygamy, and had hit upon what seemed to it to be an infallible method of granting perpetual federal control over it." 168 However, until the 1890 s, the American public, press,

163. LARSON, supra note 107, at 63 (quoting an article by Vice President Shuyler Colfax in the New York Independent, Dec. 2, 1869)

164. The national press expressed distrust as to the motives of Utah's leaders. See LyMAN, supra note 118 , at 72 . These fears might have been justified; see LYMAN, supra note 118 , at 65 n. 24 (quoting a Mormon leader as saying "Would it not be better to have these prohibiting laws administered by our own people in mediocre or minimum way than as now by our enemies and in the maximum method continually."). In the period between the Manifesto and the Enabling Act, as Congress considered statehood, important newspapers and Republican leaders requested assurances as to the finality of the renouncement of polygamy, the treatment of Gentiles by a Utah state government, and the "finality of church authorities' pledges to have retired from politics" (including a request to "reaffirm their promise not to seek 'to influence voters through the obedience of rank and file to their priestly superiors."'). LYMAN, supra note 118, at 207.

165. H.R. REP. No. 50-4156, at 52.

166. H.R. REP. No. 50-4156, at 76. As a result, the numerous proposed constitutions developed by Utahans prior to 1896 generally got short shrift from Congress. See WHITE, The Utali State Constitution, supra note 109, at 5-6 (noting that while the 1872 constitution provided for Congressional conditions, it also required voter approval in Utah of those provisions, and no one expected Mormon voters to approve a ban on polygamy); id. at 7 (describing negative reaction to 1887 constitution because of lack of trust of Mormons); Jean Bickmore White, Charter for StatehoOd: THE Story of Utah's Constitution 38 (1996) (same).

167. See LyMAN, supra note 118, at 18; H.R. Misc. Doc. No. 42-165, at 5 (1872),

168. Lerche, supra note 6, at 593-94; see also Larson, supra note 107, at 219. 
and Congress were skeptical of the trustworthiness of the Mormons; 169 it took an explicit disavowal by the church of polygamy, plus an explicit distancing of the church from politics-in short, major changes in Mormon social and political structure-to convince America that Utah could be trusted with statehood. 170

Thus, just as with the Northwest, Louisiana, and the Reconstructed Southern states, a society that was seen as heterogeneous, potentially disloyal, and foreign to American culture and politics was the subject of extensive social engineering by Congress. ${ }^{171}$ In fact, the proposals for drastic federal control, test oaths, restricted suffrage, and social engineering in Utah provide strong echoes from the debate over Reconstruction in the South. In both Utah and the South after the Civil War, Republicans in Congress believed that without fundamental social changes, the population was not suited for self-government. ${ }^{172}$ As in the South, where race relations were seen as a litmus test for the loyalty of the population to the Union, Mormon devotion to polygamy was seen as a litmus test for devotion and loyalty to the Union. 173 The conditions in the Utah Enabling Act were an example and a marker of that social engineering which "thoroughly "Americanized"" the Mormons and "prepared [them] to assume

169. See LYMAN, supra note 118 , at 51 (noting "widespread doubts about the sincerity of Mormon anti-polygamy actions"). Indeed, lack of trust on the issue meant that there were proposals for an amendment to the U.S. Constitution granting the federal government the power to regulate polygamy within the states, in order to control Utah after statehood was granted. See LyMAN, supra note 118, at 58. Some Utah supporters encouraged the amendment, seeing it as a way to speed Utah's admission. Id.

170. See White, The UTAh State Constitution, supra note 109, at 8 (stating that, for Utah to get statehood, Mormons "had to abandon the dream of a self-sufficient, religionbased commonwealth, to give up political power for a party system like those in the rest of the country, and to change the marriage practices that had drawn the wrath of the nation"); Jean Bickmore White, Charter for Statehood: The Story of Utah's Constitution 38 , 41-43 (1996) (stating that the key was Utah showing that it "finally was becoming 'Americanized"').

171. "Under prodding from some of Utah's 21,000 non-Mormons the U.S. Congress was quite willing to countenance denial of most civil rights to all of the 120,000 Mormons in the territory. And more than this, they proceeded systematically to eradicate the outward practices that highlighted Mormon distinctiveness - polygamy, cooperative enterprise, and consensus politics." MAY, supra note 106 , at 130.

172. LARSON, supra note 107 , at $65-66,76$. Larson notes the strong parallels between the Reconstruction Acts and the Edmunds Act, both of which required test oaths and restricted suffrage. Id. at 95; see also LAMAR, supra note 159, at 367, 391, 410 (noting parallels between anti-Mormon legislation and Reconstruction Acts).

173. See LARson, supra note 107, at 207 (arguing that for New England Republicans, there were direct parallels between the South and Utah and quoting a Massachusetts newspaper as saying "Not polygamy but the power of the Priesthood is the real danger"). In 1886, a "Loyal League" of Gentiles was formed in Utah to organized the "loyal citizens" of Utah against the Mormon Church; the parallels with the "loyal leagues" founded in the North during the Civil War, and in the South during Reconstruction, are striking. LARSON, supra note 107 , at 208. 
the responsibilities of citizens in the newest state in the Union."174

\section{E. Mexicans of New Mexico}

Several reasons explain why New Mexico spent one of the longest periods as a territory of any of the areas of the lower 48 , despite a population that easily might have qualified it for statehood, even in 1849 when the territory was ceded by Mexico. ${ }^{175}$ Slavery was a factor in keeping New Mexico from being admitted immediately in 1850 -New Mexicans were not enthusiastic about permitting slavery, but the South was not about to admit a free state New Mexico that would have blocked any expansion of slavery to the West. ${ }^{176}$ Conflict over the border with Texas also kept New Mexico out in 1850.177 Later on, fears by Easterners that statehood for New Mexico would add two senators supportive of free silver were a factor in preventing statehood, 178 and partisan politics played a role as well. ${ }^{179}$ Opposition within New Mexico and a perception that New Mexicans were not overwhelmingly in favor of statehood hurt the fight for admission. ${ }^{180}$ Easterners also argued that New Mexico's primarily arid climate left little potential for population growth and would result in a state with disproportionate and unfair power in Congress. ${ }^{181}$ Finally, there were concerns about corruption and dominance by railroad interests in New Mexico and its sister territory, Arizona. ${ }^{182}$

Yet one factor was especially important in the delay of New

174. MAY, supra note 106 , at 130.

175. The population of New Mexico in the 1850 census was 56,984 , just shy of 60,000 . ROBERT W. LARSON, NEW MEXICO's QUEST FOR STATEHOOD 1846-1912, at 64.

176. See id. at 50-57 (1968) for a discussion of the role of slavery in Congressional debates over New Mexico's admission in 1850; see also LAMAR, supra note 159, 72-78; Chuck Smith, The New Mexico State Constitution: A Reference Guide 2-3 (1996).

177. See LARSON, NEw Mexico's Quest, supra note 171, at 50-57. The border issue was resolved in 1850, as part of the compromise that admitted California; Texas waived its claims to eastern New Mexico in return for the assumption by the United States of Texas's debt from its period as an independent state.

178. See LARSON, New MEXICO's QuEst, supra note 171, at 181-191, 301 for a discussion of the role of silver politics in keeping New Mexico from being admitted in the $1890 \mathrm{~s}$.

179. Democrats were opposed to admitting what was seen as a primarily Republican statc in the 1870s, and Republicans were opposed to admission in the 1880 s because it was seen as primarily Democratic in that period. See LARSON, NEw MExico's QuEST, supra note 171, at 134-36, 147-148.

180. See LARSON, New MeXico's Quest, supra note 171, at 152, 302.

181. This argument was primarily made in the 1900 s during the debates over statehood. See LARSON, NEw MEXICO's QuEST, supra note 171, at 207-215, 303.

182. See Smith, The New Mexico State Constitution, supra note 174, at 5-6; John D. Leshy, The Making of the Arizona Constitution, 20 ARIz. ST. L. J. 1, 10-11 (1988) (noting that Sen. Beveridge, a main opponent of Arizona and New Mexico statehood, feared that these states would be dominated by railroad interests). 
Mexican statehood - the high proportion of Hispanics (generally descendents of the original settlers from the period of Spanish and Mexican rule) in New Mexico's population. "The unique population of New Mexico profoundly separated the territory from most of the remainder of the West where Anglo pioneers had slowly filled the frontiers with a fairly homogeneous population of Western European stock."183 An "unfortunate but instinctive distrust of New Mexico's essentially foreign culture was the last and most durable brick added to the strong wall of opposition that prevented the territory from joining the Union until 1912."184

This factor is particularly relevant given the conditions that were imposed on New Mexico's entrance into the Union in 1912: New Mexico was required to guarantee religious freedom; to provide for public schools "free from sectarian control;" 185 to ensure "that said schools shall always be conducted in English;" 186 to provide in its constitution that "ability to read, write, speak, and understand the English language sufficiently well to conduct the duties of the office without the aid of an interpreter shall be a necessary qualification for all State officers and members of the state legislature;"187 to prohibit polygamy, plural marriages, and polygamous cohabitation; 188 and to prohibit the introduction of alcohol into Pueblo

183. LARSON, NEW MEXICO'S QUEST, supra note 171, at 303

184. LaRson, New MeXico's Quest, supra note 171, at 304; see also DenNIS Baron, The English-Only Question: An Official Language for Americans? xv (1990) ("[S]tatehood was withheld from New Mexico for over sixty years because of nativist opposition in Congress to the territory's Mexican American majority population and to the prevalence of Spanish in New Mexican life."): SMITH, The New Mexico State Constitution, supra note 174 , at 1, 6, 12-13; see also id. at 8 (noting that a decline in the percentage of Mexican-Americans in the population combined with increasing assimilation of New Mexico made statehood more palatable for Congress); Leshy, The Making of the Arizona Constitution, supra note 181 , at 13.

185. New Mexico Enabling Act, $\$ 2$. This provision, originally imposed upon the Omnibus States in 1889 and upon Utah in 1896, see note 156, supra, was continued for Oklahoma, New Mexico and Arizona, and would have served similar functions for New Mexico's Catholic parochial school system (which was viewed with considerable distrust). See discussion supra. Howcver, I have found no explicit indication in the Congressional hearings or debates that this was the intended purpose of the condition.

186. Id. This requirement was also imposed in the Oklahoma Enabling Act, although Oklahoma did not have a provision requiring that public officers speak English. Oklahoma Enabling Act $\$ 3$. I have not bcen able to determine from the Congressional debates or hearings or from secondary sources why Oklahoma was required to meet this condition; however, Oklahoma did have a large Native American population (in the former Indian Territory) which might have been seen as requiring assimilation. In the hearings on the admission of Oklahoma, a Congressmen asked a local resident who was testifying whether he objected to the provision, and the resident testified that he felt it was appropriate, since there was an "unwritten law" that "English" was the "language of the United States." Hearings on Prohibition in the Proposed State of Oklahoma before the Committee on the Territories, House of Representatives, 32 (1905).

187. New Mexico Enabling Act, \$ 2 .

188. New Mexico Enabling Act $\$ 2$. The former provision essentially copied a requirement imposed on Utah, and reflected a fear of the spread of Mormonism into New Mexico from 
Indian lands and all Indian Country. 189

Many of these conditions clearly relate to the concerns of influential Easterners that New Mexico was not "American" enough for statehood and as a result the population could not be trusted with democratic self-government. These Easterners frequently portrayed the Mexican

Utah. See LARSON, NEW MEXICo's QUEST, supra note 171, at 220, 268-69; see also 36 Cong. REC. 1686-90, 1736 (1903) (discussing the threat that Mormons might take over New Mexico and Arizona). The polygamy provision was also applied to Oklahoma, and could either have reflected blind copying of provisions from enabling act to enabling act, see note 188 infra, or could have been part of a longer Congressional policy of attempting to eliminate polygamous marriage relationships among Native Americans. See NANCY F. CoTT, Public Vows: A History of Marriage and the Nation 25-28,-121 (2000) (discussing the history of attempts by federal officials to eliminate polygamy among Native Americans).

189. New Mexico Enabling Act $\S 2$. The alcohol provision was similar to a condition required of Oklahoma, Oklahoma Enabling Act, $\$ 3$, and was prompted by a concern that the allotment of Indian lands (then ongoing under the Dawes Act) and the elimination of the Civilized Tribes' reservations through the merger of the Indian Territory with Oklahoma would eliminate the federal ban on liquor sales to Indians in Indian Country, leaving Indians at the mercy of unscrupulous liquor traders. See, e.g., S. Doc. No. 55-194 (1904) ("A Memorial of the Woman's Christian Temperance Union of the United States Remonstrating") (arguing that the Oklahoma Enabling Act will pass liquor control from the federal government to the new state, which is "not committed to maintain prohibition," which is dominated by the "saloon element" and which will "substantially abandon[] and overthrow[]" the current prohibition on alcohol in Indian country, reneging on promises to the tribes to exclude alcohol from their lands, and resulting in the "awful calamity of free whisky" in the midst of the Indian tribes); see also H.R. Doc. No. 58-101, at 2 (1903) ("Memorial of W.H. Ansley, Chairman of a Committee of the Five Civilized Tribes") (objecting to joint statehood because it would allow liquor trade in the Indian Territory); J. Howard EDMONDSON, Born SOBER: Prohibition in OKLahoma, 1907-1959, at 12-14 (1971).

The exact same conditions were imposed on Arizona as were imposed on New Mexico, even though the Hispanic population in Arizona was significantly lower. See John D. Leshy, The Making of the Arizona Constitution, supra note 181, at 20, 28-29 (1988). A potential explanation is that the Arizona and New Mexico Enabling Acts were passed as a joint bill, and so it is possible that to make drafting easier, Congress simply imposed identical conditions on both states. Identical conditions (except for the requirement that public officers speak English) were also imposed on Oklahoma as were imposed on New Mexico and Arizona - even though Oklahoma also had a lower proportion of its population that did not speak English or was not of European origin compared to New Mexico. The Oklahoma Enabling Act was a joint bill passed with a law providing for joint statehood for Arizona and New Mexico, and the same explanation might apply in this case as well. Indeed, given the similarity of many of the Enabling and Admission Acts, there appears to be a long history of conditions being "cut and pasted" from one Enabling Act to another without Congress giving much thought as to whether the conditions necessarily were applicable. See Leshy, supra note 181 , at 25 \& n.134; Park, supra note 6, at 406 (noting that the requirement that state constitutions not be repugnant to the Declaration of Independence was copied "blindly" from Nevada's enabling act to subsequent enabling acts); see also 104 CoNG. REC. 9229 (1958) (statement of Rep. Bartlet) (referring to a provision in a proposed Hawaii statehood bill that would ban aid to religious schools, "That provision to which the gentleman from Indiana alludes is exactly the same as is found in other enabling bills for states."). In particular, many of the Enabling Acts have very similar language with regards to public lands conditions, even after Supreme Court jurisprudence made those requirements unnecessary. However, the states examined in this paper had new conditions imposed on them which were often very different from the conditions imposed on previous states, indicating that Congress was consciously considering the significance of the conditions it was imposing. 
population as "corrupt; the native men, indolent and cruel; and the senoritas sexually immoral," with the local Spanish culture "sadly lacking" compared with Anglo-Saxon society. ${ }^{190}$ The Catholicism of the majority Mexicans brought frequent criticism, and the Catholic church in New Mexico was accused of meddling in politics. ${ }^{191}$ And as with Utah, the South, and Louisiana, the loyalty of the Mexican population was questioned; they were perceived as potentially disloyal, hostile towards Anglo-Americans and holding "strong sympathies" for the Mexican government. 192

These criticisms continued throughout New Mexico's territorial period. The national press in the 1870 s described New Mexico as being "'almost wholly ignorant' of the English language," claimed that jury trials were not used in most of the state, described the population as illiterate and "aliens to us in blood and language."193 The Catholicism of the population was noted as a major drawback by the press, particularly the "uncontrolled sway" of the church over education in the state. ${ }^{194}$ National press such as the Chicago Tribune in the 1880s even described New Mexico's population as "not American, but 'Greaser,' persons ignorant of our laws, manners, customs, language, and institutions."195 Other papers noted the illiteracy and superstition of the population, and argued that the Mexican population would be misled by "unscrupulous rings of politicians." 196 The overall picture painted was of a population foreign to Anglo-America, uncultured, illiterate, untrustworthy, and incapable of self-government.

Even within New Mexico, there was significant opposition to statehood. As in Utah, this was by a minority of the population that, in part,

190. LARSON, NEW MEXICO's QUEST, supra note 171, at 70.

191. Id. at $71-72$.

192. $I d$. at 72 . In the 1850 s, rumors of rebellions of Mexicans helped influence "the nation to feel that a military government, or a government of reliable 'Americans', was needed in New Mexico." Id. at 73. A brief rebellion that resulted in the deaths of some Anglos immediately after the conquest of New Mexico added some basis to these rumors. Id. at 6-8; see also LAMAR, supra note 159, at 68-69. Yet, within a few years the main leaders of that rebellion would be in the territorial legislature and become leading figures of the territorial government, and one historian argues that the main focus of all MexicanAmerican politicians in New Mexico was the achievement of "home rule" within the United States. See LAMAR, supra note 159, at 87, 106, 166.

193. LARSON, New MeXICo's Quest, supra note 171, at 124-25.

194. Id. at 125. The control of the church over the parochial school system, and the lack of any public education system, would be a point used by opponents of statehood against New Mexico. See Lamar, supra note 159, at 187. Public schools were seen by AngloAmericans, and feared by Mexican-Americans, as a major tool for the assimilation and Americanization of New Mexico. See LAMAR, supra note 159, at 89, 167-169. Obtaining a public school system was seen by statehood proponents as a major requirement for getting Congressional support for statehood. See id. at 191.

195. LARSON, New MEXICO's QUEST, supra note 171 , at 148.

196. Id. 
feared the consequences of rule by the Mexican majority. "Fear of being dominated by native influences continued to arouse prejudices and antistatehood opinions" even into the twentieth century. ${ }^{197}$ Early federal officials in New Mexico, appointees who had come from outside of the state, were a frequent source of disparaging reports about the quality of the Mexican population within the state. 198

Such attitudes carried over to Congress. Throughout the $19^{\text {th }}$ Century, Congressmen described the Mexican population of New Mexico in disparaging terms, characterized it as a foreign culture and unworthy of self-government, and insisted that it was only by assimilation into mainstream Anglo-American society (including its laws and language) that New Mexico would be improved. 199 One Senator in the debates in 1902 characterized the Mexican race as:

inert; they have not yet come into contact with the American race in such a way as to be leavened and quickened and to be brought into that condition of thought which is possessed by the average American citizen. But ... when they shall have become educated, when through that education they come to mingle more commonly with the American people, when they cease to isolate themselves in their own villages and employ their own language and think their own old inherited thoughts, then it is, in my opinion, they will make a good class of citizens. ${ }^{200}$

The importance of Congressional attitudes towards New Mexico's Mexican population is revealed in two ways in the period just before statehood. First, the opposition to statehood was led by Senator Beveridge, who directed a Republican fillibuster of New Mexico statehood bills that killed admission in 1904.201 Among the arguments used by Beveridge and his allies in the Senate was that the "Mexican" character of numerous sections

197. Id. at 200; see also LAMAR, supra note 159, at I90; SMITH, THE NEW MEXICo STATE Constitution, supra note 174, at 8 . A memorial by the leading Anglos of New Mexico in 1851 said: "We are fully convinced that there is no hope for the improvement of our Territory unless Americans rule it, and that the spirit of Mexican rule must be corrupt, ignorant, and disgraceful in a Territory of the United States, and that we know from experience that under such rule, there can be no sufficient guarantees for the secure enjoyment of property, or cven life .. " LAMAR, supra note 159, at 73. Ironically, some Mexican-Americans who opposed statehood in the late $19^{\text {th }}$ Century equally feared that statehood would result in dominance by the Anglo establishment, and cultural assimilation. See id. at 190.

198. See LARSON, NEw MEXICo's QUEST, supra note 171, at 70-72.

199. See the summary of the debates and reports in Congress in BARON, supra note 179 , at 95-98 (discussing minority reports regarding New Mexico statehood that characterized the state as illiterate, backward, and unfit for statehood because of the lack of English speakers, and majority reports in favor of statehood that asserted that the majority of New Mexicans used English on a regular basis, and that assimilation was progressing rapidly).

200. 36 Cong. ReC. 361 (1902) (remarks of Sen. Dillingham); see also LARSON, New MExico's QuEsT, supra note 171, at 172-74 (describing Congressional attacks on the use of Spanish in the courts and schools of New Mexico); id. at 177 (quoting a Congressmen as criticizing Democrats for voting to admit New Mexico, populated by "a race speaking an alien language" while denying statehood to Oklahoma, "peopled by the best blood on the American continent').

201. Id. at 218-225. 
of New Mexico, the use of Spanish in everyday life in many New Mexican communities, and the ignorance of the Mexican population made New Mexico unfit for statehood. ${ }^{202}$ These sentiments were part of the opposition to admission in Congress up until New Mexico was admitted.203

These perceptions towards the Mexican population also played a role in the debates over the proposal to merge Arizona and New Mexico into one state; the Enabling Act for Oklahoma passed in 1906 also provided for joint statehood for Arizona and New Mexico, under the name "Arizona,"204 provided that both territories voted to accept the merger. In the debates over this Act, those who objected to joint statehood frequently referred to the unique Mexican population of New Mexico, its linguistic, legal, and social differences from Arizona, and the impracticability of combining two very different societies. "Arizona and New Mexico are not homogenous and never can be. They are strangers to each other and always will be. They have nothing in common and never can have. They differ in language, laws,

202. See LAMAR, supra note 159, at 490-92 (describing Beveridge as "a nativist and an imperialist" and characterizing Beveridge as believing that the "refusal to learn English was tantamount to a mild form of treason."); LARSON, NEW MEXICO's QUEST, supra note 171, at 210-212; see also S. REP. No. 57-2206, pt. 1, at 5-10 (1902) (authored by Sen. Beveridge) (noting the different language, customs and laws of New Mexico and arguing that it has not been "Americanized" sufficiently to warrant statehood); 36 CONG. REC. 574 (1903) (remarks of Sen. Nelson (an ally of Beveridge) ("[N]o territory should be admitted into the fellowship of States that is not possessed of full American homogeneity in language, and in qualifications, by training and education, for all that makes up the duties of a self-governing American citizen"); 36 CONG. REC. 723 (1903) (remarks of Sen. Nelson) ("What I am finding fault with [New Mexicans] is that they do not become Americanized, and that they still speak the Spanish language.") (also referring to the use of interpreters in New Mexico courts and bilingual publication of laws); 36 CoNG. REc. 1412 (1903) (remarks of Sen. Lodge) ("Spanish still remains in large degree the language of the mass of the population, the language of the children, the language of the juries. They are obliged to have interpreters in their courts; they are compelled to print their laws in Spanish; they must have interpreters in their political conventions. To my mind, Mr. President, that is a very serious objection ... It is a question of having a homogeneous people within the borders ot he United States, a people who are one in aspiration, in belief, in hopes, and in ideals."); Jesse de la Cruz, Rejection Because of Race: Albert J. Beveridge and Nuevo Mexico's Struggle for Statehood 1902. 1903, 7 AzTLAN 79 (1977) (arguing that racial prejudice led Beveridge to fight New Mexico's statehood, noting the use of racial prejudice by opponents to New Mexico's statehood, and contrasting the description of Oklahoma as a purely white territory deserving admission); BARON, supra note 179, at 98-102 (discussing Beveridge's opposition to New Mexico statehood, his use of the large proportion of Mexican residents and the Spanish language as an argument against admission, and a series of hearings held by Beveridge in New Mexico that emphasized the continuing use of Spanish in the territory).

203. See, e.g., 40 CONG. ReC. 3453 (1906) (remarks of Sen. Perkins) (opposing the admission of New Mexico jointly with Arizona because the merger would leave Arizona "to the domination of ignorant voters of alien blood").

204. On numerous occasions, there were proposals to change the name of the territory of New Mexico when it became a state-again, such efforts reflected in part antipathy towards the Mexican heritage of the territory. See, e.g., 36 CoNG. REC. 1366 (1903) (remarks of Sen. Lodge) ("I am perfectly certain that we ought to change the name of the Territory of New Mexico, if we are going to admit it. . . . I think we had better give the States that we admit American names.") 
customs, government, and ideals."205 Indeed, the opposition even characterized New Mexico as a "Mexican endeavoring to ascend [a] ladder and forcibly make ... [b]eautiful American Arizona ... his own."206 Arizonans expressed fears that they would be absorbed by the Mexican population of New Mexico. ${ }^{207}$ Ironically, those who promoted joint statehood, including Senator Beveridge, argued that joint statehood would accelerate the assimilation of Mexican New Mexico into the United States. ${ }^{208}$

As noted above, the final Enabling Act reflected many of these concerns. The Senate version of the Enabling Act, which is what eventually passed, "reflected the Eastern viewpoint to a far greater degree than had the original" in terms of its suspicion of the Mexican population. ${ }^{209}$ For example, the Senate added the requirement that state officers read, write, and understand the English language. ${ }^{210}$ The English language provision for public schools in New Mexico was explicitly defended by one Congressmen as necessary to accelerate the assimilation of the MexicanAmerican population in New Mexico. ${ }^{211}$ Once again, the fear of a disloyal, non-homogeneous, and un-American population in a new state had led Congress to impose conditions on statehood. 212

205. 40 CONG. REC. 1564 (1906) (remarks of Del. Smith of Arizona).

206. 40 CONG. ReC. 1504 (Jan. 24, 1906) (remarks of Rep. De Armond); see also Leshy, The Making of the Arizona Constitution, supra note 181, at 16 (noting the racist arguments against jointure).

207. See Anne Merriman Peck, The March of Arizona History 278 (1962). Railroad interests also apparently opposed jointure, as it would make domination of the individual states more difficult. See Leshy, The Making of the Arizona Constitution, supra note 181, at 15. Interestingly, by the time New Mexico and Arizona became states, at least in Arizona the railroad interests had lost prominence and a very progressive constitution was developed. See id. at 17 .

208. See, e.g., 40 CONG. ReC. 3524 (1906) (remarks of Sen. Beveridge) (arguing that the joint state will result in the Mexicans being "surrounded by the greater mass of Americans upon the east and the south and the west, who will shoot the filaments of their social activities, of their commercial and business activities backward and forward until the whole Mexican mass, of which so much complaint has been made, is Amcricanized. And when we have accomplished that we shall have done a thing of profound National benefit to the American Republic if the arguments of the opposition be true.")

209. LaRson, New MeXICo's Quest, supra note 171, at 268.

210. LaRson, New MeXICo's Quest, supra note 171, at 268. Indeed, when discussion arose in 1911 in Congress as to why the English requirement for public officers had been imposed, Beveridge was singled out as the originator of that provision. See 46 CONG. REC. 1371 (1911) (statement by Rep. Booher (quoting hearings)); see also LAMAR, supra note 159, at 497 (noting that the Enabling Act "was loaded with qualifications which revealed continued suspicion of Southwestern motives for statehood").

211. Statehood, Hearing before the Committee on Territories, United States Senate, 78 (1910) (Chair of Committee objects to an amendment adding a provision allowing the teaching of other languages in New Mexico public schools because such a provision would "continue the thing that has kept back the speaking of English and the learning of English").

212. The enabling act did eliminate an Arizona provision that required English literacy for voting in the devclopment of the state constitution. See Leshy, The Making of the Arizona Constitution, supra note 181 , at 20 . However, this provision was apparently prompted more by a fear of partisan manipulation of the voter rolls by Democrats than anything else. Id. 


\section{F. Hawaii}

The final example of how important assimilation has been in the process of admitting states comes from a condition that was never actually imposed by Congress. The Enabling Acts for Hawaii throughout the 1950s contained a condition that Hawaii require a loyalty oath for all public officials, through a constitutional provision that "no person who advocates, or who aids or belongs to any party, organization, or association which advocates, the overthrow by force or violence of the government of the State of Hawaii or of the United States shall be qualified to hold any public office of trust or profit under the State constitution." 213

The context for this proposed condition was a suspicion among some Congressmen that Hawaii could not be trusted with statehood because of Communist influence in the state's trade unions and political system. 214 Indeed, a report by the chairman of the House Interior and Insular Affairs Committee in 1949 stated that "international revolutionary communism has a firm grip on the economic, political and social life in the Territory." 215 The focus of these anti-Communist critics was the International Longshoreman's and Warehouseman's Union (ILWU) in Hawaii, which was allegedly controlled by Communist sympathizers. 216 The loyalty of Hawaii was severely questioned by certain members of Congress throughout the 1950s, who argued that Communists could take control of the Hawaiian state government, shut down Hawaii's economy in the event of war, disrupt military shipments, and gain access to sensitive military intelligence in Congress. ${ }^{217}$

The response by the Hawaiians seeking statehood was to attempt to provide clear evidence that they were loyal to the United States. A loyalty oath was required for dock workers and public employees in the territory, and a territorial version of the House Unamerican Activities Committee

213. See, e.g., H.R. 49, 83rd Cong., \$2, reprinted in H.R. ReP. No. 83-109, at 45 (1953).

214. See S. REP. No. 82-314, at 66-68 (1951) (minority report) (arguing that "[i]t would be a terrible mistake to grant statehood to any Territory whose economic life and policy is so completely dominated by Communists," that the "single really big labor union in Hawaii . . is itself absolutely controlled by known Communists," that "Communism has also penetrated very deeply into many of the leading political and social organizations of the islands," and that the Soviet Union could use a Communist-controlled state to undermine America).

215. Roger Bell, Last among Equals: Hawalian Statehood and american Politics 165 (1984). This chairman, Senator Butler, was to lead the charge against Hawaiian statehood for a number of years and to help delay statehood for years, using racial and Communist arguments. See Justus F. Paul, The Power of Seniority: Senator Hugh Butler and Statehood for Hawaii, 9 HAWAIIAN J. HIST. 140 (1975). Butler once said: "A lot of other people have asked me if I want to see two Japs in the United States Senate. No, I don t." Id. at 141 .

216. Bel.L, supra note 209 , at 166 .

217. Id. at 166-167; see also S. REP. No. 82-314, supra, at 66-68. 
was created. 218 The constitutional convention of 1950 drafted a Hawaiian state constitution (which would be adopted when statehood was finally achieved in 1959) that was itself intended to demonstrate Hawaii's fitness as a state and loyalty to the Union. ${ }^{219}$ The constitution followed traditional American lines, with separation of powers, a bicameral legislature, and protection for individual rights. 220 But perhaps most importantly, the constitution provided specifically for a loyalty oath for public officers. ${ }^{221}$ After Hawaii introduced the loyalty oath provision in its constitution, Congress apparently believed it to be an excellent idea; as discussed above, statehood bills considered until 1958 included this loyalty oath as a condition of Hawaii's admission as a state. ${ }^{222}$ The loyalty oath provision was repeatedly mentioned by supporters of Hawaii statehood, both in the Congressional hearings and in the Congressional debates, as an example of the loyalty of the people of Hawaii, and of their ability to resist Communist influence. 223

\section{BELL, supra note 209 , at 170-171.}

219. See id. at 180 (quoting a leading Hawaiian politician as stating that "Should Hawaii's State Constitution be announced by prominent constitutional authorities to be an eminently satisfactory document, it would refute charges that the islands were being subverted internally by un-American elements"); NORMAN MELlER, WITH AN UNDERSTANDING Heart: Constitution Making in Hawail 84 (1971) ("[The 1950 Constitution] showed and was meant to demonstrate how thoroughly the people of the Islands were imbued with American political and cultural traditions."); id. at 4 (describing the 1950 Constitution as a "propaganda gesture"); see also AnNe FEDER LeE, The Hawail State Constitution: A REFERENCE GUIDE 7 (1993) (noting that Hawaiians hoped that by creating their own constitution, "Congress would be convinced by its advanee adoption that the people of Hawaii accepted American values and were ready to be part of the Union.")

220. MELLER, supra note 213 , at 84.

221. "No person who advocates, or who aids or belongs to any party, organization or association which advocates, the overthrow by force or violence of the government of this State or of the United States shall be qualified to hold any public office or employment." HAW. ConST. art. XVI \$ 3 (1950); BeLL, supra note 209, at 182; LEE, supra note 213 , at 10 ("Sensitivity to congressional concerns had led the delcgates to include a loyalty oath provision without any substantial opposition."); see also RICHARd C. PRATT \& ZACHARY SMITH, Hawai'l Politics and Government: An American State in a PaCific World 104 (2000); MELLER, supra note 213, at 5 (describing the loyalty oath provision as an effort to show the loyalty of Hawaii).

222. See, e.g., H.R. REP. No. 83-109, supra, at 45.

223. See, e.g., Statehood for Hawaii, Hearings before the Subcommittee on Territorial and Insular Affairs of the Committee on Interior and Insular Affairs, House of Representatives, 85 th Cong., 2nd Session, 71, 76 (1959) (statements of Mike M. Masaoka, supporter of Hawaii statehood); Statehood for Hawaii, Hearings before the Committee on Interior and Insular Affairs, House of Representatives, 86 th Cong., 1st Session, 38 (1959) (statement of Sect. of Interior Fred A. Seaton); Statehood for Hawaii, Hearings before the Subcommittee on Territorial and Insular Affairs of the Committee on Interior and Insular Affairs, House of Representatives, 85 th Cong., $1^{\text {st }}$ Session, 67-68 (1957); Statehood for Hawaii, Hearings before the Committee on Interior and Insular Affairs, U.S. Senate, $85^{\text {th }}$ Cong., Ist Session, 9 (1957) (statement by John Burns, Delegate in Congress from the Territory of Hawaii); 105 CoNG. Rec. 4019 (1959) (remarks of Rep. Passman) (noting that no other U.S. state constitution had such a provision at the time); 105 Cong. REC. 3917 
Hawaii's efforts to prove its loyalty to the Union might have been especially difficult because, at least according to some historians, antiCommunists on the mainland and in Hawaii associated Hawaiian Communism with Hawaii's large Asian population. Much of the fundamental opposition to Hawaii's statehood might have in fact been based on fears of the racial heterogeneity of the state, with the fear of Communism serving as a proxy for those racial fears. ${ }^{224}$ In their attacks on Hawaiian statehood, opponents in Congress often closely connected their explicit racial and political fears: "It is entirely within the realm of possibility that a group of Senators, representing a way of life not in accord with ours, could easily control a balance of power in the United States Senate."225 "If Hawaii had been settled and primarily populated by Americans from the mainland, there might be no great problem about admitting it as a state. Unfortunately, that was not the case." 226 A number of the letters and

(1959) (remarks of Rep. Dwyer); 105 CONG. ReC. 3909 (1959) (remarks of Rep. Westland) (supporter of Hawaii statehood stating that loyalty provision is "highly significant"); 105 CONG. REC. 3871 (1959) (remarks of Sen. Eastland) (arguing against Hawaiian statehood, and stating that the loyalty oath provision is not a sufficient safeguard because Communists will not respect it and the courts have declared it unconstitutional); 105 CoNG. REC. 3867 (1959) (remarks of Sen. Keating); 105 CoNG. Rec. 3848 (1959) (remarks of Sen. Kuchel); 105 CoNG. ReC. 1149 (1959) (remarks of Rep. McCormick); 104 CoNG. ReC. 13737 (1958) (remarks of Rep. Byrne of Illinois)

224. See BELL, supra note 209 , at 119-120 (noting the "curious amalgam of anti-communism and racism" that was a "frustrating new obstacle to statehood"); see also Paul, supra note 209. Given the fact that in 1949 China had just been "lost" to the Communists, and in the early 1950s the main anti-Communist wars were being fought by the U.S. in Korea and by France in Vietnam, the connection between Asians and Communism could easily be made by many anti-Communist Americans. See also John S. Whitehead, The Anti-Statehood Movement and the Legacy of Alice Kamokila Campbell, 27 HAWAIIAN J. HIST. 43, 50-52 (1993) (noting that a leading opponent of statehood openly expressed fears that the Japanese-Americans would dominate a new state government); BELL, supra note 209, at 147 (arguing that opponents to statehood within Hawaii were limited to Native Hawaiian and Caucasian leaders who feared "domination by an alien, Asian population."); id. at 258-63 (making the connection between the anti-Communist movement and opposition to Japanese dominance of Hawaiian politics); LeE, supra note 213, at 7 (arguing that Hawaiians had a "strong desire to counteract congressional fears about the island's lack of similarity with the mainland because of its racial and ethnic mix and its supposed infiltration by Communists."). Indirectly, racism also played a role because Southern Congressmen, who already opposed the potential election of non-white Congressmen from Hawaii, also feared Hawaii's representatives would add support to civil rights legislation. See Paul, supra note 209 , at 145 .

225. S. REP. No. 85-1164, pt. 2, at 1-2 (1957) (minority views of Sen. Malone).

226. S. REP. No. 81-1928, at 55 (1950) (minority views of Sen. Butler). The Senator continued: "[T]he question is not of race, but primarily one of alien traditions. It will be extremely difficult to inculcate any sound concept of American ideals in a group with foreign background, dominated in its own little area, but isolated from the rest of the States." Id. at 56. Indeed, noncontiguity of Hawaii was another argument used against admission, see, e.g., id., at 54-55, and against the admission of Alaska as well. See S. REP. No. 85-1 163, pt. 2, at 1 (1957) (minority views of Sen. Malone) ("I have consistently voted against Hawaiian and Alaskan statehood mainly because this Nation has never granted statehood to 
telegrams from constituents to Congressmen opposing Hawaiian statehood also explicitly made the connection between the predominantly Asian population of Hawaii, the threat of Communism, and the inability to assimilate Hawaii into the United States. ${ }^{227}$ In response, throughout the push for statehood, statehood proponents argued that Hawaii's Asian population had been thoroughly Americanized, that Asian-language schools were on the decline, and that the Asian population spoke English, was loyal to the United States, and was capable of democratic self-government. ${ }^{228}$

Eventually Hawaii was admitted without any conditions, 229 but the loyalty oath provision remained in the Hawaiian Constitution that was adopted in 1959, an explicit reminder of how distrustful Americans had

any noncontinguous territory; and it is not conceivable to me that at this time we could ever have a homogeneous people through the acceptance of offshore areas widely separated from the mainland, where perhaps not over 1 percent of the inhabitants would ever visit the mainland. In these noncontiguous areas, a great bulk of the people have no direct knowledge of life and conditions in the United States, and because of this their ways of life are different from ours. Consequently, they are much more vulnerable to infiltration by the exponents of ideologics and theories which are contrary and dangerous to the American philosophy of life and government.")

227. See documents attached to Statehood for Hawaii, Hearings before the Subcommittee on Territorial and Insular Affairs of the Committee on Interior and Insular Affairs, House of Representatives, 85th Cong., $1^{\text {st }}$ Session, 63-64 (1959) (statement by Mrs. Margarent Hopkins Worrell, representing the "Wheel of Progress", stating that Hawaii's population is "75 percent unassimilable in our country" and that "it is a well known fact that there are a large number of Communists in Hawail"); id. at $108-113$ (reproducing letters from constituents opposing Hawaii statehood because of the Asian population, the Communist domination of the islands, and the risk of Asian immigration from Hawaii to the mainland); Statehood for Hawaii, Hearings before the Committee on Interior and Insular Affairs, House of Representatives, $85^{\text {th }}$ Cong., $1^{\text {st }}$ Session, 88-89 (1957) (letter opposing statehood because there should not be "mixing of the races which God Almighty separated by big oceans," that the Constitution "stress[es] too much on place of birth and too little on the assimilation qualification necessary to produce good citizens", and accusing the Japanese on Hawaii of aiding the attack on Pearl Harbor and stating that it was "lucky they were not all thrown into the ocean."); id. at 99-100 (editorial from Tulsa (Okla.) Tribune stating that "[t]he Japanese control elections in Hawaii. Their growing tendency is in support of communism.").

228. See, e.g., SEN. REP. No. 82-314, at 1 (1951) (describing Hawaii as a "progressive and prosperous American community" that is a "bastion of Americanism"); id. at 6-7 (providing statistics showing the Caucasian proportion of the population rising, "emphasiz[ing] that immigration of Asiatic races was stopped in 1932" and that thus "the overwhelming majority of the persons listed as of Japanese ancestry are native-born American citizens, born into and schooled in the ways of American democracy," and pointing to the loyalty of Japanese-Americans in Hawaii during World War II and the Korean War as a "conclusive, irrefutable answer to any ill-founded suggestions that these native-born American citizens of Japanese ancestry are not worthy, loyal Americans in the highest sense"); id. at 16 ("Hawaii has been thoroughly American in word, thought and deed for a half century and longer"); BELL, supra note 209, at 69-71, 87-90, 101-103. Indeed Bell, has an entire chapter dedicated to the "Americanization" of Hawaii after World War II. See id., at Chap. 4.

229. The Congressional debates and the hearings from the $85^{\text {th }}$ and $86^{\text {th }}$ Congresses (covering the period when the bills reported out of committee for the admission of Hawaii stopped including the loyalty oath condition) do not provide any indication of why the condition was dropped. 
been of Hawaii, and the lengths to which Hawaiians went to prove their loyalty and their Americanization.

\section{EFFECTS OF CONDITIONS}

As Part II has shown, many of the conditions that intruded significantly into what have traditionally been considered state matters were prompted by fears that the population of the proposed state was not "American," loyal, assimilated, or to be trusted with self-government. But what were the impacts of these conditions on the newly admitted statesdid the conditions really matter?

At one level, one can argue that the "on the ground" implications of the conditions did not matter. The mere fact that the state was admitted with explicit conditions, different from other states that had been admitted, and which were directly connected to the distrust and fear of the new state's population, was significant. The conditions were a living reminder to the new state government and people that, whatever the law might say, in a certain manner the state was not "equal" with the other states. For example, in the debate over Oklahoma's Enabling Act, which included conditions on the location of the state capital and prohibition, Senator Bailey of Texas exclaimed: "You compel [Oklahoma] to come into the Union with badges of dishonor and incompetency never before put upon a Commonwealth." 230 One representative, in discussing the imposition of conditions on Arizona and New Mexico when they were admitted, called the imposition of that Enabling Act's conditions as "unfair and unjust" and stated that the conditions did "not recognize the full sovereignty of these States when admitted into the Union." 231 In the debate over a condition that required Arizona to amend its new state constitution to eliminate recall of judges, 232 one Senator characterized the attempt of Congress to revoke the provision: "Should we degrade Arizona, and by mere power force her to change her constitution, and admit her so humbled, into the Union, every other state, being equal, will be likewise humiliated."233

230. Peter S. Onuf, New State Equality, supra note 6, at 53 (1988) (quoting 40 ConG. REC. 8390-91 (1906)).

231. 45 CONG. REC. 8486 (June 18, 1910) (remarks of Rep. Houston).

232. See Joint Resolution To Admit the Territories of New Mexico and Arizona as States into the Union upon an Equal Footing with the Original States $\$ 7,37$ Stat. 39 (1911); LAMAR, supra note 159, 503-504.

233. 46 Cong. ReC. 3681 (Aug. 7, 1911) (62 nd Congress, First Session) (remarks of Sen. Poindexter); see also Hearings before the Committee on the Territories of the House of Representatives on House Joint Resolution No. 14 Approving the Constitutions Formed by the Constitutional Conventions of the Territories of New Mexico and Arizona 72 (1911) (statement by New Mexico resident in testimony characterizing the conditions placed in the Enabling Act "as an insult" because Congress was "restricting [New Mexico] in a matter where no other State had ever been restricted"). 
Thus, the conditions themselves are markers of the uniqueness (in a negative way) of the new states, and the special burdens that they bear in the Union, if only in the minds of the Congress and the American people at the time of their admission.

Still, the conditions do not seem to have engrained themselves too deeply in the minds of the people of the states in question, or their historians for that matter. Most state history books give short shrift (if they discuss at all) the conditions that were imposed on the states when they entered, ${ }^{234}$ and the conditions are rarely (if ever) discussed in the history books after the entry of the state into the union, even when there are discussions of matters that are directly affected by the Enabling Act. For example, a book on Oklahoma Prohibition only discusses the conditions of the Oklahoma Enabling Act requiring Oklahoma to prohibit alcohol in its opening chapter, ${ }^{235}$ In the longer historical perspective the conditions appear to have faded into memory - even in the South, the ire of "Redeemers" appears to have been focused on the substantive issues of black suffrage and civil rights (and the Fourteenth and Fifteenth Amendments that enshrined these principles), rather than the fact that these requirements were also imposed through the readmission conditions. 236

At another level, one could examine the manner in which the courts have explicitly treated the conditions-while Coyle $v$. Smith established the modern doctrine that intrusive conditions were unconstitutional, the history of admission conditions case law might show that the courts, before Coyle, had historically enforced such conditions against the states.

And at a third level, one could examine whether after admission the new state continued on the path of assimilation and loyalty that Congress

234. For examples of the discussion of Enabling Act conditions in general state history books, see, e.g., MAY, supra note 106, at 128 (which does not even discuss the condition in the Enabling Act banning polygamy); Gustave O. Larson \& Richard D. Poll, The Forty-Fifth State, in UTAh's History 387, 392 (Richard D. Poll ed. 1978) (same); Charles S. Peterson, Utah: a Bicentennial History 104 (1977); John S. Goff, Arizona: An Illustrated History OF THE GRAND CANYON State 95-96 (1988) (only discussing the recall condition for admission of Arizona); THOMAS E. SHERIDAN, ARIZONA: A History 175178 (1995) (same); WARREN A. Beck, New Mexico: A History of Four Centuries 239241 (1962) (only mentioning "several progressive amendments" and "protective fcatures" in the New Mexico and Arizona Enabling Act); James R. Scales \& DanNey Goble, OKLAHOMA POLITICS: A HISTORY 20 (1982) (discussing only the capital location and prohibition conditions in Oklahoma's Enabling Act); H. WAYNE MORGAN \& ANNE Hodges MORgan, OKLAhIOMA: A BicentenNial History 81 (1977) (noting the same conditions). But see White, The Utah State Constitution, supra note 109, at 57 (describing the "irrevocable" nature of the Enabling Act provision governing polygamy in Utah as "considered by some to be an unnecessary - perhaps humiliating - part of Utah's Constitution”).

235. J. Howard Edmondson, Born Sober: Prohibition in OKLahoma, 1907-1959, Chap. 1 (1971).

236. See discussion at notes 281-297 and accompanying text, infra. 
had intended to impose with the conditions. Was the strategy of assimilation, of which conditions were only a part, successful in incorporating the state into American society?

\section{A. Case Law of Admission Conditions}

The basic hornbook law that most lawyers know regarding the admission of states to the Union is the "equal footing" doctrine. Under this doctrine, the Supreme Court has held that Congress can not impose conditions on a state's entry that would place that state on an unequal footing with the existing states. The doctrine is based primarily on two main cases: Coyle v. Smith, ${ }^{237}$ and Pollard's Lessee v. Hagan ${ }^{238}$-and is currently understood to have two major implications. One, Congress can not constitutionally impose a condition on the admission of a state that otherwise would be outside Congress's power to legislate for any other state, 239 and two, certain attributes of state sovereignty (most notably, ownership of the submerged lands beneath navigable waters) are assumed to be transferred to all states upon entry into the Union, since those attributes were inherited by the original thirteen states upon independence. ${ }^{240}$

Beyond the hornbook understanding of the caselaw, however, there is a much deeper and richer history of courts interpreting and understanding the conditions imposed on state admission by Congress. Among the surprising features of the case law regarding admission conditions is the general absence of court cases challenging the power of Congress to impose conditions on states regarding languages, family law, court procedures, or qualifications of public officials. Of all the admission conditions cases that reached the Supreme Court until Coyle v. Smith, only two involved conditions that did not involve public lands, navigation of waterways, and Indian affairs. One was a challenge to a New Orleans ordinance that allegedly violated the religious liberties requirement of the Louisiana Enabling Act; 241 another case involved the enforceability of the ban on slavery in the Northwest Ordinance. 242 The lack of cases challenging

237. 221 U.S. 559 (1911).

238. 44 U.S. 212 (1845).

239. Coyle, 221 U.S. at 573-74.

240. Pollard's Lessee, 44 U.S. at 228-29.

241. Permoli v. City of New Orleans, 44 U.S. 589 (1845)

242. Strader v. Graham, 51 U.S. 82 (1850). A fair number of lower federal court decisions have involved other conditions, however, and have generally followed the Supreme Court's lead in not enforcing those conditions. See, e.g., McCabe v. Atchison, Topeka and Santa Fe R.R. 186 F. 966, 968-69 (1911) (holding that the Enabling Act provision preventing racial discrimination in Oklahoma was not enforceable after the state Constitution is approved by Congress), aff $d$ on other grounds by 235 U.S. 151 (1914). 
these conditions may reveal the relative effectiveness of Congress's assimilation efforts for these states, as discussed below. ${ }^{243}$

Nonetheless, in those admission conditions cases that the Supreme Court did decide, even before Coyle $v$. Smith, the Court limited Congress's power to impose conditions on the states. ${ }^{244}$ Among the earliest was Permoli. In a case in which the plaintiffs challenged a city burial ordinance that arguably infringed on freedom of worship guaranteed by the Louisiana Enabling Act, the Court held that "the laws of Congress were all superseded by the State Constitution." 245 As a result, any violation would have to be redressed in state court, not federal court. 246

Pollard's Lessee v. Hagan was decided in the same year. In a dispute over whether a grantee from the federal government, or from the State of Alabama, held title to intertidal submerged lands, the Court rejected the federal grantee's claims based on title from the federal government and the Alabama Enabling Act, which prohibited the state from interfering with navigation on navigable waters and required the state to disclaim all title to waste lands within the state. ${ }^{247}$ Depriving the state of jurisdiction over submerged lands after it had been admitted would place the state on an unequal footing vis-à-vis other states, the Court held. 248 The condition of the Enabling Act requiring Alabama to disclaim all title to waste lands within the state could not "diminish or enlarge" Alabama's rights as an equal state-they therefore could not be interpreted to restrict the state's ability to grant lands under navigable waterways after statehood, and thus the state grantee won. ${ }^{249}$

243. One case did indirectly involve the conditions imposed on states. In Bolln v. Nebraska, 176 U.S. 83 (1900), a convicted defendant argued that his conviction without use of a grand jury indictment violated the Fifth Amendment. Because Nebraska's constitution was required to be consistent with the Constitution when it was admitted, Nebraska Enabling Act $\S 4$, the defendant argued that the state constitution violated the Enabling Act when it allowed prosecutions without indictments. The Court held that Nebraska's admission only required the state to accept the supremacy of the federal Constitution, and because the Constitution did not require grand jury indictments by the states, there was no violation. The Court added: "It is impossible to suppose that, by such indefinite language as was used in the enabling act, Congress intended to differentiate Nebraska from her sister states, even if it had the power to do so, and attempt to impose more onerous conditions upon her than upon the others, or that in cases arising in Nebraska a different construction should be given to her Constitution from that given to the constitutions of other states." Id. at 87.

244. For an excellent overview of the Supreme Court's jurisprudence in the field of admission conditions, see Onuf, New State Equality, supra note 6.

245. Permoli, 44 U.S. at 610.

246. Id.

247. Pollard's Lessee v. Hagan, 44 U.S. 212 (1845).

248. Id. at 229. Broadly interpreted the decision could be seen as depriving Congress of jurisdiction over the territories "except for temporary purposes, and to execute the trusts" created by state land cessions and international treaties. See Onuf, New State Equality, supra note 6 , at 63 .

249. Pollard's Lessee, 44 U.S. at 229. 
Moreover, the Court in Pollard's Lessee hinted at the Coyle distinction between admission conditions that are valid because they are within Congress's other powers with respect to all states, and those that are invalid as being outside those powers. The Court stated that Congress could not exercise "municipal sovereignty" (i.e., general police powers) within the borders of Alabama after statehood, and only conditions that were related to the protection of Congressional rights with respect to the public lands, or were part of Congress's power to legislate on interstate commerce (such as free navigation of waterways) could be enforced. 250 Regulation of the granting of lands beneath navigable waterways would be outside of the federal power for any other state and so could not be applied to Alabama. 251

In interpreting a number of enabling act conditions that prevented new states from restricting the freedom of navigation on navigable rivers, 252 the courts built on the principle of state equality to hold that those provisions did not deprive the states of the power to provide improvements on the rivers, charge reasonable tolls to pay for the river improvements, or build bridges. ${ }^{253}$ The courts thus narrowly interpreted an important (and consistently applied) condition in order to not deprive the new states of a power that the older states had consistently held, despite the fact that the condition was clearly within Congress's Commerce Clause powers. 254 The courts usually resolved the contradiction by holding that the Congress could intervene, if it so chose, to

250. Id. at $224-25,228-30$.

251. Id.

252. Many states were required to promise that they would not interfere with navigation on ccrtain (or all) navigable rivers. See, e.g., Louisiana Enabling Act § 3; Alabama Enabling Act, $\S 6$; Oregon Admission Act, $\S 2$. These conditions apparently responded to fears by upstream states that downstream states such as Kentucky, Ohio, or Louisiana might attempt to raise revenue through the taxation of traffic on rivers such as the Ohio and Mississippi.

253. See, e.g., Sands v. Manistee River Improvement Co., 123 U.S. 288 (1887); Cardwell v. Americal River Bridge Co., 113 U.S. 205 (1885); Escanaba \& Lake Michigan Transp. Co. v. City of Chicago, 107 U.S. 678 (1883); Withers v. Buckley, 61 U.S. 84 (1857); Huse v. Glover, 15 F. 292 (C.C. N.D. Ill. 1883), aff'd 119 U.S. 543 (1886); Depew v. Bd. of Trs. of Wabash \& Erie Canal, 5 Ind. 8 (1854); Duke v. Cahawba Navigation Co., 10 Ala. 82 (1846). But see Spooner v. McConnell, 22 F. Cas. 939 (1838); Hogg v. Zanesville Canal \& Mfg. Co., 5 Ohio 410 (1832) for early cases that held that the states could not infringe on the navigation of rivers through improvements or tolls to pay for improvements.

254. There is a trend in the caselaw to narrowly interpret restrictions in enabling acts, usually to allow the states maximum flexibility under those enabling acts. See, e.g., Edwards v. Lesueur, 33 S.W. 1130, 1134-35 (Missouri 1896) (refusing to interpret a grant of land by the federal government for the construction of a state capital as implying a prohibition on the state from moving its capital); Romine v. State, 34 P. 924, 925-26 (Wash. 1893) (holding that the state did not violate its Enabling Act through disposition of land without a public sale, because the state constitution allowed for other methods of transferring state trust lands, and the President and Congress approved the state constitution by admitting Washington and therefore implicitly accepted changes to the Enabling Act). 
prevent unreasonable tolls or navigation; however, there was no specific intervention by Congress to prevent the particular improvements, tolls or other obstructions, and on the facts of the particular cases, there was no obstruction of the waterways in violation of the conditions (even if Congress had the power to impose them) which the court interpreted as intended solely to prevent obstruction for revenue-raising purposes alone. 255 Often accompanying these decisions was strong language in favor of the equality of states:

Whatever the limitation upon [the state's] powers as a government while in a territorial condition ... it ceased to have any operative force, except as voluntarily adapted by her after she became a state of the Union. On her admission she at once became entitled to and possessed of all the rights of dominion and sovereignty which belonged to the original states. She was admitted, and could be admitted, only on the same footing with them. ${ }^{256}$

In Strader v. Graham, the Court held that the slavery prohibition of the Northwest Ordinance had no more binding effect after the state had been admitted; otherwise, the Ordinance "would place [the states] in an inferior condition as compared with other states, and subject their domestic institutions and municipal regulations to the constant supervision and control of this court." 257 A lower federal court later held that the Northwest Ordinance could not prevent Indiana from allowing felony trials without a jury. 258

Thus, long before Coyle $v$. Smith the Court was setting strict limits on Congress's powers under the Admissions Clause, and was laying the groundwork for Coyle's distinction between valid and invalid conditions. The decision in Coyle v. Smith was not a dramatic change in Supreme Court jurisprudence, but instead the culmination of a long trend of cases.

At the same time as the Court was restricting Congress's power to impose conditions that interfered with what it viewed as core concepts of state sovereignty in areas outside of federal power, it was increasing Congress's power over the federal lands within the territories and the new states, and using that power to uphold federal conditions related to federal lands in newly admitted states. As Table One and the Appendix shows, Congress often imposed restrictions on the taxation of federal lands, ${ }^{259}$

255. See, e.g., Escanaba, 107 U.S. at 688-689.

256. Escanaba, 107 U.S. at 688-689.

257. Strader, 51 U.S. at 96.

258. Williams v. Hert, 110 F. 166 (C.C. D. Ind. 1901) ("The ordinance of 1787 and the other acts above quoted have ceased to operate as limitations on the powers of the state.")

259. The Northwest Ordinance included the first conditions regarding public lands; it required that future states in the Northwest Territory promise to never interfere "with the primary disposal of the soil by the United States," to never interfere with federal regulation of titles of public lands, to never tax federal lands, and to never levy discriminatory taxes against non-resident land owners. Article IV of the Northwest Ordinance, reenacted as 1 Stat. 50. 
prohibitions on the interference with the disposal of federal lands, 260 restrictions on the use of lands granted to the states, and disclaimers of all jurisdiction over lands reserved to Indian tribes. ${ }^{261}$ Conditions related to federal lands granted to newly admitted states were often particularly significant because of the large amounts of land that new states were given. ${ }^{262}$ Initially, no or minimal conditions on the management and use of state land grants were imposed. ${ }^{263}$ However, stories of fraud, waste and abuse by the states with respect to the lands and revenues they had obtained through the admissions land grant process led to the imposition of more stringent conditions on New Mexico and Arizona. ${ }^{264}$ A related

260. Many states were required to accept the initial disclaimer required by the Northwest Ordinance that future states in the Northwest Territory promise to never interfere "with the primary disposal of the soil by the United States." Article IV of the Northwest Ordinance, reenacted as 1 Stat. 50. Louisiana was required to disclaim all waste or unappropriated lands as well as any claim to federal lands. Louisiana Enabling Act $\$ 3$.

261. For instance, Kansas was required to disclaim jurisdiction over Indian lands. Kansas Admission Act, $\S 1$. After Kansas's admission, most Western states were required to disclaim jurisdiction over Indian country. See, e.g., New Mexico and Arizona Enabling Act $\S \S$ 2, 20; Omnibus Enabling Act $\S 4$ (same). Congress has also required states to prohibit the introduction of intoxicating liquors into Indian reservations. See New Mexico and Arizona Enabling Act, $\S \S 2,20$ ("the sale, barter, or giving of intoxicating liquors to Indians and the introduction of liquors into Indian country ... are forever prohibited"); Oklahoma Enabling Act $\$ 3$ (prohibiting the liquor trade into the former Indian Territory for 21 years after statehood, and providing for specified penalties for violations).

262. From the admission of Ohio onwards, newly admitted states were granted significant amounts of land for various purposes, including road improvements, education, and construction of government buildings. For example, Florida eventually received over 24 million acres of land, much of it through swampland grant provisions, or over $64 \%$ of its total state area, while Ohio received 2.7 million acres of land, or just over $10 \%$ of its total state area. See Paul W. Gates \& Robert W. Swenson, History of Public Land Law Development Appendix C, pp. 804-806, and 294-316 (1968) for a discussion of the amounts and purposes of the various kinds of grants given to the states. Some grants were also made outright without any intended purposes, and other grants involved the sharing of revenues from all public lands sold within the borders of the state. When Ohio was first admitted to the Union, Congress granted it significant lands, including lands for common schools, salt springs, and $5 \%$ of the net proceeds from sales of federal lands within the state in order to pay for road construction to the state. Ohio Enabling Act $\$ 7$; see also Act of March 3, 1803, 2 Stat. 225 (altering the land grants and revenue sharing arrangement pursuant to request by Ohio Convention). These grants were in part intended to placate settlers who opposed the large amounts of federal land in Ohio, and also to compensate for the further requirement that Ohio not tax federal lands sold within the state for a period of five years after sale. See GATES, supra at 288-289.

263. See, e.g., Ohio Enabling Act $\$ 7$ (imposing no conditions on management and use); Michigan Admission Act (imposing only the condition that lands be used for the purposes granted); see also Branson School Dist. RE-82 v. Romer, 161 F.3d 619, 633 (10 th Cir. 1998) (describing the history of school land grant conditions); MatThIas NordBERG ORfIELD, Federal Land Grants to the States with Special Reference to Minnesota 49-52 (1915) (stating that "Up to 1889 . . . no attempt was made to control the action of the states in regard to the" sale of federal land grants to the states)

264. These states were required to allocate the lands and funds from specific grants for specific purposes in separate accounts, and to use the education funds solely for state schools; they were further required to promise that the lands were to be held "in trust" with 
restriction imposed on a number of states after the admission of Montana, Washington, and the Dakotas, required states to use federal land grants intended for the state educational system, often quite significant in amount, solely for "the establishment and maintenance of a system of public schools, which shall be open to all children ... and free from sectarian control." 265

In the late $19^{\text {th }}$ Century, the Court upheld the power of Congress to prevent state taxation of federal lands within territories and states, thereby confirming the effectiveness of admission conditions related to exemption of federal property from taxation. 266 The Court was careful to emphasize, however, that the federal powers in this matter came from the Constitution, not from the admission compacts or conditions themselves. 267 Similarly the Court has since upheld conditions on the use of federal lands and federal land grants by the states. 268 Even if unequal distribution of federal lands within the states meant that newer states would, in effect, face an increased burden from the same federal land conditions compared to older states that had little federal lands within their borders,

the United States retaining the power to suc over breaches in court, that grant lands could not be mortgaged, that grant lands had to be sold to the highest bidder at an advertised public auction after appraisal, that leases of grant lands had to be for short terms, and that all transactions in violation of the land grant conditions were void. Arizona and New Mexico Enabling Act, $\$ 10$. Many of these stringent restrictions on the resale of lands granted by the federal government to New Mexico and Arizona and on the use of those funds by the states were prompted by Congressional concerns that many state lands had been sold at too low a price, had been used as political favors instead of revenue sources to build state government and educational institutions, and had been subject to other forms of fraud and abuse. "The dissipation of the [state land grant] funds by one device or another, sanctioned or permitted by the legislatures of the several states, left a scandal in virtually every state, and these granted lands and the monies derived from a disposition thereof were so poorly administered, so unwisely invested and dissipated, that Congress concluded to make sure, in light of experiences in the past that such would not occur in the new states of New Mexico and Arizona." Murphy v. State, 181 P.2d 336, 350-351 (Ariz. 1947) (discussing the background of the New Mexico and Arizona Enabling Act public land conditions); see also S. REP. No. 61-454, at 18-20 (1910) (discussing the restrictions, and explaining that their purpose is to reduce fraud and waste, and to raise the revenue from the land grants by increasing the sale prices); H.R. REP. No. 61-152, at 3 (1910) (discussing the need for minimum sale prices to increase revenue to the states); 45 CoNG. REC. 8227 (1910) (remarks of Sen. Beveridge) (same); ORFIELD, supra note 256, at 48-49; Leshy, The Making of the Arizona Constitution, supra note 181 , at 26-27.

265. Omnibus Enabling Act $\S 4$. For a more detailed discussion of the provision, see note 156 , supra.

266. Van Brocklin v. Tennessee, 117 U.S. 151 (1885).

267. Id. at 167-68.

268. See, e.g., Asarco Incorporated v. Kadish, 490 U.S. 605 (1989) (holding that state system of mineral leasing on state lands violated Enabling Act); Lassen v. Arizona, 385 U.S. 458 (1967) (holding that state system for payment of highway construction over trust lands violated Enabling Act); Ervien v. U.S., 251 U.S. 41 (1919) (prohibiting New Mexico from spending state trust fund proceeds on advertising for tourism, as it was not one of the expenditures authorized under the Enabling Act). 
there was no infringement of state equality; this was still true even if new states had agreed to substantially different (and more disadvantageous) conditions related to those federal lands. 269 The Court summarized the distinction between conditions that implicated the equal footing doctrine and those that did not as a "political versus property" distinction, with the former subject to searching review for possible unequal impacts on states, and the latter subject to little review. 270

As a result, conditions related to federal and Indian lands and the grants of lands by the federal government to the new states, have been uniformly upheld by the courts as within Congress's power. ${ }^{271}$ The results

269. See Stearns v. Minnesota, 178 U.S. 223 (1900). "In an inquiry as to the validity of such a compact this distinction must at the outset be noticed. There may be agreements or compacts attempted to be entered into between two states, or between a state and the nation, in reference to political rights and obligations, and there may be those solely in reference to property belonging to one or the other. That different considerations may underlie the question as to the validity of these two kinds of compacts or agreements is obvious. It has often been said that a state admitted into the Union enters therein in full equality with all the others, and such equality may forbid any agreement or compact limiting or qualifying political rights and obligations; whereas, on the other hand, a mere agreement in reference to property involves no question of equality of status." Id. at 244-45; see also Nevada v. United States, 512 F. Supp. 166 (D. Nev. 1981) (holding that "[f]ederal regulation which is otherwise valid is not a violation of the 'equal footing' doctrine merely because its impact may differ between various states because of geographic or economic reasons" and therefore the large amount of federal land in Nevada can be placed under stringent management restrictions without violating the equal footing doctrine).

270. See Stearns, 179 U.S. at 244-45 (1900) (as quoted in note 268, supra); see also Branson School Dist. RE-82 v. Romer, 161 F.3d 619, 635-36 (10 $0^{\text {th }}$ Cir. 1998) (upholding constitutionality of conditions imposed on granting of lands to Colorado at the time of its admission as within Congress's power). The property-political distinction has also been used to reject claims by states that greater holdings of land by the federal government within a state compared to other states places that state on an unequal footing. See Nevada v. U.S. Dept. of Energy, 914 F.2d 1545, 1554-55 (9th Cir. 1990) (relying on political-property distinction to reject Nevada's claim that the siting of a nuclear waste disposal facility on federal land in Nevada infringed on equal footing); Nevada v. United States, 512 F. Supp. at 171 (relying on the distinction to reject claim by Nevada that federal control of vast majority of Nevada land placed Nevada on an unequal footing); see United States v. Texas, 339 U.S. 707, 716-18 (1950) (rejecting Texas's claims to submerged lands off of the coast of Texas, and stating that control of the off-shore lands is an inherent part of national sovereignty, and therefore equal footing requires that the federal government instead of Texas control such lands, and discussing the political-property distinction).

271. For cases holding that Congress may properly restrict state jurisdiction over Indian lands through the enabling acts, see, e.g., U.S. v. Sutton, 215 U.S. 291, 117-118 (1909); The Kansas Indians' Cases, 72 U.S. 737, $755-757$ (1866). This power was not based on the enabling acts, but on the power for Congress to legislate with respect to Indian affairs. See U.S. v. Sandoval, 231 U.S. 28, 38-48 (1913) (upholding Congress's power to prohibit importation of liquor into Pueblo communities in New Mexico, and stating that the power does not arise from the restrictions in the New Mexico and Arizona Enabling Act, but from Congress's power to regulate Indian affairs) (citing Coyle v. Smith); Hallowell v. U.S., 221 U.S. 317, 323-24 (1911) (upholding power of Congress to prohibit liquor importation into Indian Country within Nebraska); Dick v. U.S. 308 U.S. 340, 348-57 (1908) (same within Idaho). These cases essentially overruled earlier cases in which the Court had held that Congress could not use its powers over Indian affairs or its Enabling Act powers to restrict 
have been sometimes significant intrusions into state jurisdiction and power-in particular, in Arizona and New Mexico, where the Enabling Acts were particularly stringent in their restrictions on the use of funds and lands from the statehood grants. Thus, in New Mexico, the Enabling Act requirement that state school lands granted by the federal government only be used for non-sectarian schools was enforced by the state supreme court-the court relied in part on state constitutional requirements that had been imposed by the Enabling Act as well as the Enabling Act itself in requiring the defunding of all sectarian schools, and the barring of sectarian books, doctrine, garb, and insignia from all public schools. 272 The case was significant because at the time a substantial number of rural public school systems in New Mexico were still operated by the Catholic Church. 273 Other cases in Arizona and New Mexico required substantial reorganization of the state government bureaucracy involved in the management of state trust lands, and in how those lands were managed, leased and the revenues used. ${ }^{274}$ Courts in other states have also upheld the

state sovereignty over Indian Country. See In re Heff, 197 U.S. 488, 500-505 (1905) (holding that Congress could not restrict the sale of liquor to Indians granted citizenship and allotted lands within Kansas); Ward v. Race Horse, 163 U.S. 504, 512-16 (1896) (holding that provision of Enabling Act requiring Wyoming to disclaim jurisdiction over Indian lands could not support excluding Wyoming from regulating hunting by Indian tribal members who were given, by treaty, the right to hunt on unoccupied lands of the United States). The result in Race Horse can perhaps be explained not by the fact that Congress sought to exclude state regulation over Indian tribes, but because the language of the treaty was so vague, and the area of land to be covered by the tribes was so broad, that the Court felt the intrusion was too great. But later cases have upheld the rights of Indians under treaties to hunt and fish throughout a state under their treaty rights. See, e.g., U.S. v. Winans, 198 U.S. 371 (1905) (upholding right of Indians under treatics to fish without restriction throughout Washington); see also Minnesota $v$. Mille Lacs Band of Chippewa Indians, 526 U.S. 172, 204-08 (1999) (stating that Race Horse "rested on a false premise" and holding that tribe had retained hunting and fishing rights in a wide area of Minnesota).

The Court has also held that disclaimers by states in the admission process of jurisdiction over Indian Country are irrelevant to whether states can exercise jurisdiction over criminal law involving non-Indian on non-Indian crimes within Indian country. Compare U.S. v. McBrateny, 104 U.S. 621 (1881) (holding that because Colorado did not disclaim jurisdiction over Indian tribes when it was admitted, it may prosecute a non-Indian for committing a crime against a non-Indian within the borders of a tribal reservation) with Draper v. U.S., 164 U.S. 240, 247 (1896) (holding that despite such a disclaimer, Montana has exclusive jurisdiction over such crimes in Indian country because the disclaimer "was not intended to deprive that state of power to punish for crimes committed on a reservation or Indian lands by other than Indians or against Indians").

272. Zellers v. Huff, 236 P.2d 949 (N.M. 1951).

273. Zellers, 236 P.2d at $951-54$ (listing the schools where Catholic church was involved in education and describing the scope of that involvement).

274. See, e.g., Asarco Incorporated, 490 U.S. at 605 (holding that state system of mineral leasing on state lands violated Enabling Act); Lassen, 385 U.S. at 458 (holding that state system for payment of highway construction over trust lands violated Enabling Act); Ervien, 251 U.S. 41 (1919) (prohibiting New Mexico from spending state trust fund proceeds on advertising for tourism, as it was not one of the expenditures authorized under the Enabling Act); U.S. v. New Mexico, 536 F.2d 1324 (10 th Cir. 1976) (requiring New Mexico to 


\section{Enabling Act conditions relating to the public lands. 275}

We thus return to the hombook summary of the "equal footing" doctrine: The current case law draws a clear distinction between conditions that can be imposed by Congress as part of its normal constitutional powers (which are enforceable by the courts without violating the equal footing doctrine) and those that can not be imposed by Congress because they exceed the powers that it would otherwise have. ${ }^{276}$ Indeed, this distinction appears to begin developing early in the nineteenth century. The case law

operate a miners hospital as required by Enabling Act, instead of using funding to serve miners at general hospitals); Roosevelt Elementary School Dist. No. 66 v. Bishop, 877 P.2d 806 (Ariz. 1994) (holding state funding scheme for local education violative of both state constitution and Enabling Act); Fain Land \& Cattle Co. v. Hassell, 790 P.2d 242 (Ariz. 1990) (holding state land exchange program violates Enabling Act); Gladden Farms, Inc. v. State, 633 P.2d 325 (Ariz. 1981) (holding state land exchange program among state agencies violates Enabling Act); State Interstate Stream Commission v. Reynolds, 378 P.2d 622 (N.M. 1963); Shepard v. Mechem, 250 P.2d 897 (N.M. 1952); State v. Vesely, 52 P.2d 1090 (N.M. 1935).

Arizona has unilaterally altered a few federal land provisions in its constitution that were mandated by its enabling act. See John D. Leshy, The Arizona State Constitution: A REFERENCE GUIDE 240, 326 (1993) (noting that Art. X $\$ 3$, Art. XX $\$ \S 5,10$ have been altered); see also Leshy, The Making of the Arizona Constitution, supra note 181 , at $24 \& \mathrm{n} .132$.

275. See, e.g., Bartels v. Lutjeharms, 464 N.W.2d 321 (Neb. 1991) (holding valuation of payments for certain leased school lands violated state's trust duty under Enabling Act); Skamania v. State, 685 P.2d 576 (Wash. 1984) (holding that state's subsidy of logging on state lands was violation of trust duty under Enabling Act to maximize revenue for education from those lands).

276. Onuf argues that it was because of the broad expansion of federal power over public lands in the territories and the states that the courts began to be willing to hold certain conditions unenforceable - by expanding the power of the federal government in federal lands, the conditions that related to federal lands (the majority of conditions) could continue to be enforced, and the power of the federal government to manage the public lands and the settlement of the West would not be threatened. See Onuf, New State Equality, supra note 6, at 63-67.

For other attempts to explain the case law (usually in a manner that is more favorable to state power, and in order to show that federal jurisdiction over public lands within states is unconstitutional), see Hanna, Equal Footing in the Admission of States, supra note 6, at 524532 (arguing that Congress can only enforce conditions either before the admission of a state (in all cases) or after the admission of a state if the condition is otherwise within Congress's power); Julien C. Monnet, Violation by a State of the Conditions of Its Enabling Act, 10 CoLuM. L. Rev. 591 (1910) (arguing that Enabling Acts are essentially contracts, that states can not contract away essential attributes of sovereignty, that the location of a state capital is such an essential attribute of sovercignty and therefore the Oklahoma Enabling Act condition on the location of the Oklahoma state capital is unconstitutional, and distinguishing the Indian jurisdiction and public lands conditions by arguing that they only diminished the geographic scope, and not the essential powers, of the state); C. Perry Patterson, The Relation of the Federal Government to the Territories and the States in Landholding, 28 TEXAS L. REv. 64-69 (1949) (arguing that the "equal footing" doctrine is irrelevant, citing the long historic practice of Congress attaching conditions to admission, and instead arguing that it is the reserved powers clause of the Tenth Amendment that prevents encroachment on state sovereignty through conditions, that therefore any federal condition that intrudes upon such reserved powers violates the Tenth Amendment, and that the use of federal conditions to require states to not tax federal lands and to disclaim jurisdiction over those lands shows that the federal government does not have the constitutional power to own lands within states, and these conditions should be struck down). 
is accompanied by strong language that affirms the sovereignty of the new states, and their equality. 277 Yet Congress continued to attempt to impose conditions even into the $1950 \mathrm{~s}$, sometimes with barely a clue as to the case law that implied its conditions would not be enforced by the courts. 278 Why would Congress impose seemingly futile conditions? The answer, perhaps, is that even if the conditions were not enforced in court, they nonetheless may have had an impact on the states upon which the conditions were imposed.

\section{B. The Effectiveness of Conditions on State Governments and Societies}

Overall, the conditions regarding issues such as language, governmental structure, and other internal matters that Congress imposed on states had a mixed record of effectiveness. Some of the states abided by their conditions, perhaps in large part because the assimilation process of which the conditions were a part had succeeded; in others, the conditions became a dead letter, unenforced and ineffective.

The states of the Old Northwest did, in general, comply with the requirements of the Ordinance. Slavery was generally excluded from them; 279 the civil liberties marked out in the Ordinance were generally

277. For a more recent example of such language, see Barlow v. Blackburn, 165 Ariz. 351 , 355 (Ariz. App. 1990) (stating that "Congress must admit new states on an equal footing with the other states and may not deprive a newly-admitted state "of any of the power constitutionally possessed by other States" and that therefore the requirement in the Enabling Act that polygany be banned in Arizona is repealable at will by the state). However, there are some early decisions that carry the opposite language, marking off a jurisprudential path not taken. See, e.g., Brittle v. People, 2 Neb. 198 (1872) (stating that provision barring racial discrimination that was imposed by Congress in admitting Nebraska, and was agreed to by legislature, was a valid requirement, and could not be breached by the state) (") [W] hen, on its part, Congress raised us to the dignity of Statehood; gave us representation in Congress, and a voice in the affairs of the nation; donated to use munificent grants of land and money - all for the small consideration that we would do justice to a few theretofore proscribed people - it behooves us to keep faith and abide by the terms of admission.").

278. Thus, even in 1911, the year of Coyle v. Smith (but before the decision itself), during the debate over Arizona's recall provision a member of the House of Representatives could insist on Congress's power to impose conditions on states. "If the Congress had the power heretofore to require such fundamental constitutional provisions as conditions precedent upon which the proposed new States were to be admitted, it seems to me that it has the power today to require of any of her Territorics that seek admission that the proposed State constitution of that Territory should carry a fundamental provision." 46 CoNG. REC. 1346 (May 18, 1911) (statement of Rep. Kahn); see also 46 CoNG. REC. 1351 (May 18, 1911) (discussion among Reps. Hamilton, Flood and Utter to the effect that Congress clearly can impose conditions on states). But see, e.g., 46 CoNG. REC. 1364 (May. 19, 1911) (remarks of Rep. Humphreys of Mississippi) (calling the English requirement for New Mexico public officers "utterly useless" and citing caselaw).

279. However, limited forms of slavery existed in Illinois and Indiana throughout the early nineteenth century. These forms of slavery were usually characterized by the territorial and state governments as "involuntary servitude" in order to avoid the ban of the Ordinance. See Onuf, STATEHOOD AND UNION, supra note 6, at 116-132. 
accepted by the Northwest states (and indeed, by all American states) in their new constitutions; 280 and the states of the Old Northwest were peopled by Anglo-Americans (or assimilated Europeans) who were among the most loyal to the Union. ${ }^{281}$

Louisiana also is an example of successful conditions. As noted above, it had already adopted the jury for all court proceedings, including criminal ones; the first state constitution met all the requirements of the Enabling Act, ${ }^{282}$ as did all subsequent constitutions. In particular, Louisiana always at the least required the use of English for its public records until the mid-nineteenth century, when the use of English became so predominant that the requirement was dropped from the constitution. ${ }^{283}$ The state has also continually protected in its constitution the

280. See, e.g., ILL. CONST. art. VII (1819) (providing for right to jury trial, freedom of speech and press and religion, and protecting private property against scizure by the state); Mich. CONST. art. I (1836) (same); IND. Const. art I (1816); Ohlo Const. art. VIII (1802). But see Williams v. Hert, $110 \mathrm{~F}$. at 155 (allowing Indiana to have felony trials without a jury).

281. See EBSEN, supra note 19, at 102-103 (noting the "rapid increase of Anglo-American settlement in the West" in the first decade of the $19^{\text {th }}$ Century, and the resulting relaxation of federal control over the territories because of "the simple realization that native-born AngloAmericans would predominate in the territories and that close supervision would not be necessary to assure the development of eastern forms of republicanism.").

282. See Louisiana CONST., Art VI § 15 (requiring all public records to be in English); $\S$ 18-19 (providing for bail, habeas corpus, right to counsel, confrontation of witnesses, and jury trial for criminal defendants); $\$ 21$ (providing for freedom of the press, speech and thought) (1812); see also CECIL MORGAN, THE FIRST Constrtution of THE STATE OF LOUISIANA 6-7 (1975) (noting that the state constitution explicitly complied with the Enabling Act, despite the contemporary use of French in the state government). The first constitution did attempt to protect the use of substantive civil law, however, by prohibiting the wholesale adoption of a code of laws by the legislature, which it was feared would result in the adoption of the common law. Another constitutional provision requiring judicial opinions to be based on specific reasons and particular legislative enactments was also seen as a "hedge[] against limitless intrusions of common law into Louisiana jurisprudence." See Warren M. Billings, From This Seed: The Constitution of 1812, in IN SEARCH OF Fundamental LaW: Louisiana's Constitutions: 1812-1974, at 6, 17 (Warten M. Billings \& Edward F. Haas, eds. 1993). Thus, assimilation only went so far in early Louisiana. A strict property requirement in the early constitution was also an effort to maintain the French elite in power. $I d$. at 22; see also TREGLE, supra note 58, at 55-60 (1999)

283. Indeed, the 1845 constitution explicitly permitted the use of French in the legislature because the French-Louisianans feared they were to be overwhelmed by the rising tide of American immigrants and residents. See Judith K. Schafer, Reform or Experiment? The Louisiana Constitution of 1845, in IN SEARCH OF FUNDAMENTAL LAW, supra note 276, at 21 , 31; see LA. Const. \& 104 (1845). The Louisiana Constitutions of the 1850 s and 1860 s eventually dropped language requirements. See Wayne M. Everard, Louisiana's 'Whig' Constitution Revisited: The Constitution of 1852, in IN SEARCH OF Fundamental Law, supra note 276, at 37, 46; Kathryn Page, A First Born Child of Liberty: The Constitution of 1864, in IN SEARCH OF Fundamental LAw, supra note 276, at 52, 52. During the debates over the 1864 constitution, some of the delegates expressed strong hostility towards the use of French. One called the official use of French "a nuisance" that "ought to be abolished in this State or any other. . . If there are any in the State who cannot speak, read or write the language, they should learn to do so before they reside in the country any longer." BARON, 
criminal defense rights and other general religious and political liberties that were mandated in the Enabling Act. ${ }^{284}$ And while in the early nineteenth century until the Civil War there was an undercurrent of tension between the "ancien" French population and the immigrant AngloAmericans, ${ }^{285}$ nonetheless, Louisiana eventually became a state where English was the dominant language, and in general American political and social traditions were followed. 286

The conditions imposed on the Southern states during Reconstruction, however, were only complied with briefly, if at all. The readmitted Southern states did ratify the Fourteenth Amendment, and all of the readmitted states did provide for black suffrage. 287 However, within thirty to forty years after the readmission of the Southern states, all of them had amended their constitutions or used statutory changes to effectively deny suffrage to blacks through a variety of tools, including grandfather voting clauses, "understanding" clauses that required the voter to show to the local registrar that the voter understood the state or federal constitution, literacy tests, poll taxes, broad provisions for disenfranchisement for a range of crimes, 288 and even the secret

supra note 179, at 85 (1990) (quoting OfFicial. Journal of thF. Procefoings of the CONVENTION FOR THE REVISION AND AMENDMENT OF THE CONSTITUTION OF THE STATE OF LOUISIANA 47 (1864)). Another called French language schools an "evil." Id. at 86. The state constitution eventually shifted from requiring the use of English for all public acts, see LA. Const. art. VI $\S 15$ (1812); LA. Const. art. 103 (1845); LA. Const. art. 100 (1852); LA. CONST. art. 103 (1864), to also requiring the use of French in addition to English (probably as French Louisianans began to experience assimilation), see LA. CoNST. art. 103 (1845); LA. CONST. art. 129 (1852). Eventually, this requirement for English was dropped (probably as it became irrelevant since English was by far the more important language), and the constitution began to allow the General Assembly to publish laws in French, but not to require its use. LA. CONST. art. 154 (1879); LA. ConST, art. 165 (1913). The modern Louisiana Constitution does not even mention the language that its acts are to be published in, again showing the dominance of English. LA. CONST. art. III (1974).

284. See. e.g., LA. CONST. art. VI $\$ \$ 18-21$ (1812); LA. ConST. arts. 110, 107 (1845); LA. Const. arts. 106, 103 (1852); LA. Const. arts. 4-8 (1879).

285. See generally, TREgLE, supra note 58 , for a discussion of Louisiana politics and society from the 1810 s until the 1840 s.

286. But see Breakthrough, supra note 6, at 149-151, 1407-8 (arguing that Louisiana's French population successfully resisted a great deal of assimilation, and noting the continuation of Louisiana's civil law system); Roy F. Nichols, The Louisiana Purchase: Challenge and Stimulus to American Democracy, 38 Louisiana HisT. Q. 1, 6 (1955) (same).

287. See, e.g., FLA. CONST. art. XV $\S 1$ (1868) (extending franchise to "every male person ... of whatever race, color, nationality, or previous condition" who is a citizen); .GA. Const. art. II $\$ 2$ (1868) (extending franchise to "every male person born in the United States"); MISs. CONST. art. VII $\S 2$ (extending franchise to "all male inhabitants" who are "citizens of the United States"); N.C. ConST. art. VI $\$ 1$ (1868) (extending franchise to "every male person born in the United States"); VA. CONST, art. III $\$ 1(1870)$ (extending franchise to "every male citizen of the United States").

288. Criminal disenfranchisment is one of the few post-Reconstruction tools used to disenfranchise blacks that continues to be applied today, with a disproportionate impact on poor blacks voting throughout the country. See J. Morgan Kousser, The Undermining of the First 
ballot. 289 Of course, widespread voter intimidation, fraud, and violence were additional tools used by the Ku Klux Klan, White Leagues, and similar institutions, as well as the Democratic Party, to eliminate black votes in addition to the legal tools used by the Southern states. ${ }^{290}$ Fraud, intimi-

Reconstruction: Lessons for the Second, in MinORITY VOTE DILUTION 27, 34-35 (Chandler Davidson ed. 1984); Andrew L. Shapiro, Note, Challenging Criminal Disenfranchisement Under the Voting Rights Act: A New Strategy, 103 YALE L. J. 537, 537-39 (1993) (describing the historical context by which criminal disenfranchisement was explicitly used to reduce black voting).

289. Compare the constitutions cited in note 281, supra, with FLA. CONST. art. VI (1885) (requiring voters to pay any poll tax enacted by the legislature); GA. CONST. art. II (1877) (requiring voters to have "paid all taxes which may hereafter be required of him"); Miss. CONST. art. 12 (1890) (requiring voters to live in the state two years, in the locality one year, to have paid poll taxes for the past two years plus the current year, to "be able to read any section of the constitution of this State" or to "be able to understand the same when read to him, or give a reasonable interpretation thereof'); N.C. CoNST. art. VI (1876) (requiring voters to meet registration requirements, to be "able to read and write any section of the Constitution in the English language," unless the voter could vote before January I, 1867, and requiring all voters to pay a poll tax for the previous year); VA. CoNST. art. II (1902) (requiring voters to be resident of the state for two years and of the locality one year, to pay all poll taxes, and to be "able to read any section of this Constitution submitted to him by the officers of registration and to give a reasonable explanation of the same", or to own taxable property, or to be a person who served in the U.S. or Confederate armies or a son of a veteran). For secondary sources discussing the comparisons, see, e.g., 4 AlCÉE ForTIER, A History OF LOUISIANA 235 (1904) (noting that the 1898 Louisiana Constitution imposed educational and property requirements on voters, but exempted descendents of people who could vote before 1867 ("grandfather clause") and stating that the purpose of the clause was "to allow many honorable and intelligent but illiterate white men to retain the right of suffrage ... [but] to disenfranchise the ignorant negroes who had been a menace to the civilization of the State" and quoting the Governor as saying that the changes allow for "white supremacy" to be "crystallized into the Constitution" without "subterfuge or other cvasions"); PATRICK, supra note 101, at 281-82 (describing the "Second Mississippi Plan" which relied on "understanding clauses" in which voters were required to demonstrate understanding of any provision of the U.S. or state constitution to effectively disenfranchise blacks through inequitable application by local registrars, and the adoption of this clause by other southern states, as well as the use of poll taxes to exclude black voting); Richard LOWE, REPUBliCANS AND RECONSTRUCTION IN VIRGINIA, 1856-1870, at 183-84 (1991) (noting that the 1902 constitution eliminated most black and some poor white voting); JERrELl H. SHOFNER, NOR IS IT OVER YET: FLORIDA IN TIE ERA of ReCONSTRUCtion, 344 (1974) (noting the use of the poll tax in the 1885 Florida Constitution to exclude blacks); see also McLaughlin v. City of Canton, 947 F. Supp. 954, 969-970 (S.D. Miss. 1995) (providing a historical overview of the process by which Mississippi disenfranchised black voters through statutory and constitutional changes from the 1870 s to the 1900s); Brown v. Bd. of School Comm'rs, 542 F. Supp. 1078, 1083-94 (S.D. Ala. 1982) (providing an overview of the disenfranchisement of black voters in Alabama); U.S. v. Louisiana, 225 F. Supp. 353, 363-381 (E.D. La. 1963) (providing a detailed history of the disenfranchisement of blacks through violence, fraud, intimidation, grandfather clauses, literacy tests, and the white primary from the 1870 s until the 1960s).

290. See GILLETTE, supra note 89 , at $27-46$ (discussing the violence in the South, and the inability of federal troops or law enforcement to effectively protect black suffrage in the 1870 s and $1880 \mathrm{~s}$ ); $i d$. at 150-162 (discussing the "Mississippi plan" of race war rhetoric, threat of force, and force by Democrats to disenfranchise blacks and eliminate the Republican party as a political force in the $1870 \mathrm{~s}$ ); id. at 229.233 (discussing widespread violence in the 1874 election which was part of a "spreading pattem of Negro disenfranchisement and Republican defeat"); id. at $311-312$ (noting that by 1876, Democrats had 
dation, violence, and lack of federal enforcement of voting laws, and the resulting decline in black voter participation would have not have been prevented by the conditions themselves. In fact, it was a desire to move away from the methods of fraud and violence, towards "legal" methods of disenfranchisement of blacks, plus a worry that even diminished black suffrage might give blacks the balance of power should whites be divided, that led Southern states to amend their laws and constitutions to deprive the blacks of the vote, and thus to explicit violation of the Reconstruction readmission conditions. 291

The use of the secret ballot to effectively deny suffrage to many illiterate blacks and whites might appear ironic, but at least one historian has argued that the secret ballot combined with complex voting procedures effectively and dramatically reduced black and poor white voter turnout throughout the South. The secret ballot, which made the ballot more inaccessible to illiterate voters than the traditional party ballot (which often had been color-coded), especially when voting officials only assisted poor whites or Democratic voters with the ballot, was a common tool used by Southern governments to consciously reduce black voter participation (and to a great extent, poor white voter participation as well).292 Complex ballot

effectively completed the disenfranchisement of blacks through most of the South, with Florida, Louisiana and South Carolina, the last Republican-run states in the South, being the focus of fraud and violence). Thus, Gillette concludes that by the 1880s, the Republican party had given up on the South and the black voter, and concentrated on dominating the North and Midwest in order to maintain national power and preserve the gains of the war. See id. at 372-375; see also PATRICK, supra note 101, at 158-160 (discussing the "Mississippi Plan"); SHOFNER, supra note 283, chap. 13 (1974) (describing the use of political violence by Democrats to end black suffrage).

291. See FORTIER, supra note 283, at 235 (quoting the Louisiana Governor as saying that the constitutional changes deprive blacks of suffrage without "any fear as to the honesty and purity of nur future elections"); PATRICK, supra note 101, at 278-83 (describing the use of direct rule of local governments by Southern states, gerrymandered election districts, fraud, confusing registration requirements, and intimidation to restrict the black vote in the 1870 s and $1880 \mathrm{~s}$, and noting that the constitutional and legal changes in the South in the 1890s and 1900 s to deprive blacks of the vote was prompted by fears of Northern interference to protect black suffrage, by fears of a split white vote giving blacks a balance of power, and disputes over the extent to which black-majority counties should have reduced representation and to which poor white counties should see marginal disenfranchisement in order to remove black voting power); Frank Johnston, Suffrage and Reconstruction in Mississippi, 6 Publications of THe Miss. Hist. Soc. $205-208$ (1902); Michael L. Lanza, Little More than a Family Matter: The Constitution of 1898 , in IN SEARCH OF Fundamental Law: Louisiana's Constitutions, 1812-1974, at 93, 94-95, 99-103 (Warren M. Billings \& Edward F. Haas eds., 1993) (noting that the goal of the 1898 convention was to prevent a split in white votes allowing blacks to hold the balance of power, and noting the efforts by the convention to find means by which to restrict black suffrage without removing the vote from poor whites); see also J. MORGAN KousSER, THE SHAPING OF SOUTHERN POlITICS: SUFFRAGE RESTRICTION AND THE ESTABLISHMENT OF THE ONE-PARTY SOUTH, 1880-1910 at 11-34 (1975) (describing similar motivations).

292. See Kousser, supra note 285 , at 51, 110-113, 124-125, 134, $173-75$ (1975) (describing the use of the secret ballot in Tennessee, Alabama, Arkansas, and Virginia to consciously reduce Republican and black voting). 
schemes included the "eight-box" system in Georgia, where each ballot for each office had to deposited in the correct ballot box or be void. This system was apparently quite effective in reducing voter turnout by blacks and was copied by a number of states, including North Carolina. ${ }^{293}$ Cumulative poll taxes, in which new voter registrants were required to pay all past accumulated poll taxes in order to vote, were another extremely effective tool to eliminate voting by poor blacks and whites in Georgia. ${ }^{294}$

At least some of these methods of voter restriction (the secret ballot and multiple ballot boxes, as well as requirements for frequent reregistration, which generally fell hardest on poor and infrequent voters) ${ }^{295}$ would have been permissible under the conditions imposed on the Southern states in Reconstruction, at least if only a literal interpretation of those conditions was applied-thus, one can argue that the conditions would not have completely prevented restrictions on black suffrage, even if no violence had occurred and the conditions had been enforced. Nonetheless, these particular tools might have had reduced effectiveness over time as Republicans trained their voters in the new systems, and as black education increased. As a result, many Southern states did turn to the more explicit restrictions on suffrage (restrictions that clearly did violate the readmission conditions), often after having used the secret ballot, discriminatory registration, and multiple ballot boxes to depress black turnout in the votes for the constitutional conventions that implemented those more explicit restrictions. ${ }^{296}$

The Southern constitutional conventions that wrote these provisions were aware that their actions violated the readmission conditions that required them to not abridge the suffrage of classes of citizens who held the right the vote in 1867 or 1870; however, in Mississippi (the state that led the way in the disenfranchisement of blacks, and whose methodstermed the "Second Mississippi Plan"-would be modeled by other states) the constitutional delegates believed that the conditions were not binding on them. 297 Thus, Mississippi and other Southern states explicitly298 disregarded the conditions imposed on them by Congress in their readmis-

293. See id. at $50,86,190$.

294. $l d$. at $210-11$.

295. See id. at 47

296. See id. at 161-162, 173-175, 190-192 (describing this pattern in Louisiana, Virginia, and North Carolina).

297. Johnston, supra note 285, at 214-27 (1902) (noting that the 1890 Mississippi Constitutional Convention had convened a special committee to examine whether the conditions of the readmission act of 1870 could be binding on the state, and that the committee had concluded that the conditions were not binding).

298. Indeed, the Mississippi Supreme Court devoted a large portion of an opinion to note that the recent suffrage amendment was devoted to the beneficial purpose of excluding black voters. See Ratliff v. Beale, 20 So. 865, 867-69 (Miss. 1896). 
sion. ${ }^{299}$ While the Supreme Court never considered the legality of any Southern voting restrictions under the Reconstruction readmission conditions, those lower federal courts that did consider the issue usually summarily dismissed the conditions as unenforceable infringements of state sovereignty. 300 The Supreme Court and lower federal courts, for a period from around 1900 until the 1950 s, also used the "political question" doctrine to avoid considering whether many Southern suffrage restrictions were constitutional or legal, ${ }^{301}$ although a few were struck down on constitutional grounds even before the civil rights movement of the $1950 \mathrm{~s}$ and 1960s. ${ }^{302}$ Other cases upheld the laws against Fifteenth Amendment challenges as not explicitly racial distinctions, and therefore permissible. ${ }^{303}$

299. One historian argues that Republican deference to states rights, even during Reconstruction, prevented them from imposing enforcement provisions in the readmission bills for the South that might have given Congress the power to prevent lack of compliance. Sen. Stevens had proposed that the readmission bills explicitly give Congress the power to void non-compliant state legislation and constitutions, but this proposal was rejected. See HYMAN, supra note 101 , at 520-22.

300. See Butler v. Thompson, 97 F. Supp. 17, 20-21 (E.D. Va. 1951) (upholding Virginia poll tax against challenge based on the Reconstruction readmission conditions, because the matter is for Congress to enforce and because the condition violates the equal footing doctrine, citing Coyle v. Smith). Southern state courts, of course, upheld the provisions against challenges. See, e.g., Atwater v. Hassett, 11 P. 802, 812-13 (Okla. 1910) (upholding state's literacy and grandfather clauses against challenge based on the Oklahoma Enabling Act provision requiring that the state Constitution "make no distinction in civil or political rights on account of race or color").

301. See Giles v. Harris, 189 U.S. 475 (1903); Kousser, Undermining the First Reconsiruction, supra note 282 , at 41 . Kousser notes that at the same time, Congress refused to hear claims of black voters who challenged the election of Southern Democrats under these suffrage provisions because Congress felt it should defer on such "judicial questions" to the courts. Id.

302. In particular, the Supreme Court struck down "grandfather clauses" as violating the Fifteenth Amendment. See Lane v. Wilson 307 U.S. 268, 275-77 (1939) (striking down an Oklahoma registration statute that attempted to continue the effectiveness of grandfather clause); Guinn v. U.S., 238 U.S. 347, 364-67 (1915) (striking down Oklahoma's grandfather clause).

303. See Williams v. Mississippi, 170 U.S. 213, 222-225 (1898) (upholding Mississippi's poll tax, literacy requirements, and understanding clause as not a violation of the Fifteenth Amendment, despite explicit evidence from Mississippi's constitutional convention that the intent was to deprive blacks of the vote); see also Lassiter v. Northampton County Bd. of Elections, 360 U.S. 45, 51-54 (1959) (upholding a literacy test against Fourteenth, Fifteenth and Seventeenth Amendment challenges); Breedlove v. Suttles, 302 U.S. 277, 283 (1937) (upholding Georgia's poll tax against a Fourteenth Amendment challenge); Pope v. Williams, 193 U.S. 621 (1904) (upholding Maryland's poll tax against a Fourteenth Amendment challenge); Trudeau v. Barnes, 65 F.2d 563, 564 (5 $5^{\text {th }}$ Cir. 1933) (upholding Louisiana literacy and understanding clause requirements against Fifteenth Amendment challenge); Darby v. Daniel, 168 F. Supp. 170 (S.D. Miss. 1958) (upholding a 1955 amendment to the Mississippi constitution to strengthen the literacy and understanding clause requirements against a Fourtcenth Amendment challenge).

In a similar vein, Oklahoma enacted a series of segregation laws (including segregated schools and public transportation) as well as a literacy test and grandfather clause voting restriction, despite the Enabling Act condition that required it to provide civil rights to all 
On the other hand, Utah has continued to prohibit polygamy since the 1890 s, and the Mormon church reaffirmed its prohibition on polygamy in the early twentieth century after a series of media scandals raised the possibility that polygamy had not been abandoned.304 Prosecutions for polygamy still occur in Utah, where the courts have upheld the polygamy ban as consistent with the equal footing doctrine, because Utah "voluntarily" consented to the ban and has maintained it as a state law ever since. 305 The two-party system continues to function in Utah. ${ }^{306}$

citizens regardless of race. Philip Mellinger, Discrimination and Statehood in Oklahoma, 49 Chronicles of OKLAHOMA 340 (1971). The school segregation provisions were placed in the original state constitution, but the transportation provisions were not placed in the constitution, and instead were enacted through statute, primarily because the constitutional convention delegates feared that President Roosevelt would not approve the state constitution if they were included. $I d$. at 366-67. The grandfather clause was struck down eventually by the Supreme Court, see note 296, supra, and later attempts to further restrict suffrage failed eventually. See Irvin Hurst, The 46'Th StaR: A History of OKLAhOMa's ConStitutional CONVEntion and EARLy Statehood 155-60 (1957); Mellinger, supra, at 373-75. Of course, under the jurisprudence of the time, none of these actions were seen to violate the Enabling Act condition, since the literacy test was not perceived as racial, and school and transportation segregation were not political, but social rights. However, it is significant that the constitutional convention did adjust its bchavior in order to obtain Presidential approval of the new state constitution.

304. See MAY, supra note 106 , at 128 (noting that plural marriages continued sporadically until 1904); see also LYMAN, supra note 118, at 292-95 (noting that one Utah senator was attacked in the early 1900 s for allegedly supporting plural marriage). But see Gokdon, supra notc 109 , at 234-36 (noting that in the early $20^{\text {th }}$ Century the Mormon church remained powerful economically and plural marriages continued, although eventually the Mormon church fully disavowed the practice).

In developing Utah's constitution in 1896 , its drafters made efforts to specifically address Congressional concerns about polygamy, separation of church and state, and educational issues. See White, The Utah STATE Constitution, supra note 109, at 26-27 (noting that Art. I $\$ 4$ of the Utah state constitution, which covers church-state relations, was seen by its drafters as the "cornerstone of the commitment by the constitution's framers to guarantee religious freedom and separation of church and state in Utah and to overcome the perception in the rest of the nation that Utah was a de facto Mormon theocracy"); see also WHITE, CHARTER FOR STATEHOOD, supra note 167 , at 46, 59, 84-85.

305. See Potter v. Murray City, 760 F.2d 1065 (10 hir Cir. 1985) (civil rights suit by a Utah police officer fired for practice of plural marriage); Oliverson v. West Valley City, $875 \mathrm{~F}$. Supp. 1465 (D. Utah 1995) (civil rights suit by a Utah police officer disciplined for adultery); State v. Barlow, 153 P.2d 647 (Utah 1944) (prosecution of defendant for polygamy upheld); see also Barlow v. Blackbum, 798 P.2d 1360, 1364 (Ariz. Ct. App. 1990) (upholding the termination of an Arizona police officer for polygamy, and rejecting the claim that anti-polygamy laws resulted from the violation of the equal footing doctrine through Enabling Act condition).

Nonetheless, there are still a number of polygamists in Utah. See WHrTE, THE UTAH STATE Constitution, supra note 109 , at 58 (noting lax law enforcement on the issue in general, except in two periods during 1944 and 1953); id. at 59 (stating that there has been little interest in Utah in prosecution of polygamists in Utah so long as they maintain a low profile, with an estimate in 1983 that 5-10,000 individuals lived in polygamous households).

306. Of course, the Mormon Church continued to be a factor in Utah politics after statehood. Even after statehood, the Church maintained involvement, either through attempts to maintain a two-party balance in the state (in order to avoid having the state isolated with one party or another), see MAY, supra note 106, at 160 (noting that the Mormon Church pushed 
In New Mexico, the constitutional convention apparently followed the letter of the requirements of the enabling act, ${ }^{307}$ even while it attempted to provide some protections for the Mexican-American population in the territory. ${ }^{308}$ Soon after the passage of the Enabling Act, the admission bill for New

followers to join the Republican party, which was dominant at the time), or (later on) to push for particular policy outcomes. See F. Ross Peterson, Utah Politics Since 1945, in UTAH's HISTORY 515, 516-518 (Richard D. Poll ed. 1978). Immediately after statehood, there were concerns among some non-Mormons that the Church was continuing to meddle in politics - these concerns arose from the dominance of the Republican Party (backed by the Mormon Church) in the early twentieth century, and a church policy requiring church approval before church leaders could run for political office. See MAY, supra note 106, at 160; Thomas G. Alexander, Political Patterns of Early Statehood 1896-1919, in UTAH's HISTORY, supra, 409, 411, 415416. One of Utah's first senators, Senator Smoot, went through a lengthy set of Senate hearings over whether he was involved in polygamous marriages before he was able to obtain his seat, and for about ten years, a small anti-Mormon party (the American Party) was organized in the early twentieth century. Id. Still, historians generally conclude that the Mormon Church is no longer unusually involved in politics (at least compared to other churches), see Alexander, supra, at 417, Richard D. Poll, An American Commonwealth, in UTAH's History, 669, 676; see also Charles S. Peterson, Utah: A Bicentennial History 166 (1977) (noting that Mormons after statehood emphasized their patriotism in order to differentiate the new Utah from the previous Utah); Jan Shipps, Utah Comes of Age Politically, 35 UTAH HIST. Q. 91 (1968) (arguing that despite the Smoot hearings and the American Party throughout the early twentieth century the Mormon church actively moved to withdraw itself from the political and economic arena, and also reemphasized the ban on polygamy). But Mormonism remains one of the fundamental points of identity in Utah. See MaY, supra note 106, at 196.

307. During the hearings on the New Mexico Constitution in Congress in 1911 (as Congress was considering whether to require changes), numerous New Mexico politicians, including delegates to the constitutional convention, insisted that the convention had felt bound by the enabling act to include provisions that they were not satisfied with. See, e.g., Constitution for the Proposed State of New Mexico, Statements, Committee on the Territories, House of Representatives, 52 (Feb. 1911) (statement of Mr. Nicholson, AntiSaloon League of America) (stating that the convention "was compelled to insert" a provision in the Enabling Act banning alcohol sales to Indians, despite its preference to leave "the liquor question" to legislation); Hearings before the Committee on the Territories of the House of Representatives on House Joint Resolution No. 14 Approving the Constitutions Formed by the Constitutional Conventions of the Territories of New Mexico and Arizona, 54 (1911) (stating that there was a fight over the English-only office-holder provision in the convention but that the convention "simply accepted it because they were compelled to do so" by the Enabling Act); id. at 117-18 ("There are some things which were put into this constitution by force of the enabling act and not by the will of the people expressed in any way."). There was also testimony in the hearings that the citizens of New Mexico voted for a constitution that they were not satisfied with because they were so desparate for statehood, and that the New Mexico constitution was made so difficult to amend and so conservative because the indication was that such a constitution was required to obtain Presidential approval of the new constitution. See Hearings before the Committee on the Territories of the House of Representatives on House Joint Resolution No. 14 Approving the Constitutions Formed by the Constitutional Conventions of the Territories of New Mexico and Arizona, 114-15 (1911).

308. While the new state constitution did comply with the letter of the Enabling Act, it did appear to make efforts nonetheless to protect the Spanish-speaking minority in the state. Thus, the state constitution requires the legislature to provide for the training of teachers in English and Spanish, and to "facilitate the teaching of the English language and other branches of learning" to Spanish-speaking pupils. N.M. ConST. art. XII $\S 8$. The constitution also guarantees the right of children of Spanish descent to attend desegregated and equal schools. $I d . \S 10$. The constitution also protected the right of Mexican-American residents to vote and to hold 
Mexico repealed the condition that public officers in the state speak, read and understand English without an interpreter. ${ }^{309}$ The rationale given for repealing the requirement was that it was, in effect, an unfair discrimination against Spanish speakers in the state. ${ }^{310}$ However, over the past eighty years English has become the dominant language of education, government, business, and public transactions throughout the state, rendering the requirement essentially unnecessary. 311 As noted above, the requirement that New Mexico only support non-sectarian schools also contributed towards the elimination of Catholic instruction in public schools and the defunding of public-supported parochial schools in the state in the 1950 s, significant steps given the historic importance of the Catholic church in education in New Mexico. ${ }^{312}$

And in Hawaii, while the condition of a loyalty oath was removed from the proposed Admission Act bills before the state was actually admitted, the loyalty oath remains in the state constitution, although amended to reduce its scope and its chilling effect on free speech. ${ }^{313}$

office (except as restricted by the Enabling Act). Id. art. VII $\S 3$; see also Hearings before the Committee on the Territories of the House of Representatives on House Joint Resolution No. 14 Approving the Constitutions Formed by the Constitutional Conventions of the Territories of New Mexico and Arizona, 24 (1911) (statement by witness that the provision was included to protect the right to vote of the Mexican-American minority); id. at 36; BARON, supra note 179 , at 103 (stating that the New Mexico constitution "softened" the English-only requirements for education and office holding); LAMAR, supra note 159, at 33-34, 100, 139-40 (describing provisions of state constitution designed to protect Spanish-speaker rights). Nonetheless, these provisions indicate some desire to assimilate the Mexican-American minority, particularly the provision facilitating the teaching of English - and the constitution strictly avoided contradicting the Enabling Act. See also 46 Cong. Rec. 1372 (May 19, 1911) (statement by Rep. Booher) (stating that New Mexicans included the English-only provision because they believed that they were bound by the enabling act). But see Breakthrough, supra note 6, at 1416-1419 (arguing that these provisions show New Mexico's desire to fight assimilation). English is no longer a requirement for holding public office in New Mexico, as this was removed by a later constitutional amendment; however, the original constitution followed the Enabling Act's requirement on this issue. N.M. ConsT. art XXI \$ 5 (1912). The restrictions in the constitution as to English-speaking office holders were removed by the New Mexico voters almost immediately after Congress repealed the requirement.

309. Joint Resolution to Admit the Territories of New Mexico and Arizona as States into the Union Upon an Equal Footing with the Original States \$ 6, S. J. Res. 57, 37 Stat. 39 (1911).

310. See 46 Cong. ReC. 1251 (May 16, 1911) (statement of Rep. Legare); 46 Cong. ReC. 1364 (May 19, 1911) (calling the English requirement a "plain, direct, and in my opinion unwarranted attack on the Spanish-American citizens of New Mexico") (statement of Rep. Humphreys of Mississippi).

311. See BARON, supra note 179, at 104 (arguing that "for much of the twentieth century, despite legal efforts to protect Spanish speakers, their language was stigmatized in New Mexican schools, and students were punished for using Spanish on school grounds."); id. at 166 (discussing the punishment of children in New Mexican public schools for using Spanish in school).

312. See note 266 , supra.

313. See LeE, Hawail State Constitution, supra note 213, at 190-191. 


\section{CONCLUSION: LESSONS FOR THE AMERICAN VERSION OF STATE SOVEREIGNTY}

The history of admission conditions shows that Congress, at the time of the very creation of new sovereign states that would become part of the federal American government, has not considered the sovereignty of those states to be the most important factor to be considered. Instead, concerns over the development of a loyal population and government that can be easily assimilated into the United States federal system have been important enough for Congress to impose conditions on the entry of states.

Both the symbolic and practical implications of the imposition of conditions are significant. At the very moment in which new sovereigns are created by the federal government, they are symbolically marked by the conditions-marked both as subject to the powers and control of the federal government, and in some cases marked as different from their sister states because of religious, racial, linguistic, or political characteristics. Thus, the history of admission conditions shows that state sovereignty in American history has not only been compromised to further the goal of assimilation, but also that sovereignty has been unevenly protected, depending on how the newly admitted state has been perceived by the current members of the Union.

One could argue that the judicial enforcement of admission conditions, and the "equal footing" doctrine that developed from it, cuts against these symbolic implications. By ruling in Coyle that Congress could only impose conditions that it otherwise had the power to enact against all of the states through its other constitutional powers, the Supreme Court did make a powerful statement about the enforceability and validity of many of these conditions. But on the other hand, the line that the Court drew was not entirely protective of state sovereignty in the admission process - while Congress might be limited in the tools that it could use (such as the use of conditions that prohibited changes in state constitutions or laws after admission), Congress nonetheless had enormous power through its land grant authority and its regulation of federal lands within the states to control the admitted states. By granting lands to the new states with certain conditions, and restricting the power that the states had over lands that continued to be under federal control, the federal government retained significant powers over the new states-the secularization of New Mexico schools in the 1950s in part because of the conditions on state school land grants is a reminder of the importance of conditions that continue to be enforced by the courts today, and the degree with which they can intrude into state government. ${ }^{314}$

314. See also TRIBE, supra note 8 , at $\$ 5-22$, at 388 (stating that "the limits recognized in decisions like Coyle $v$. Smith encompass little beyond the continued formal existence of separate and independent states"). 
Thus, the practical consequences of the public lands conditions can be significant-in the case of states such as New Mexico and Arizona, judicial enforcement of conditions has resulted in significant changes in the governmental structure of the states. But even in areas where, according to the doctrine of Coyle, Congress supposedly had no power to legislate through admission conditions, Congress has nonetheless legislated and had enormous impacts on the political system and society of the admitted states-either directly through the conditions themselves, or indirectly through the political pressure Congress exerted on territories that sought admission and depended on the grace of Congress for that admission. In states such as Utah and Louisiana, the struggle over whether the state should be admitted, and on what terms, was part of a process of assimilation and social change that had deep implications for the societies in question. Even in the South, where the readmission conditions were ultimately futile, they were part of an extended contest between Republicans and Democrats over the future of politics and race relations, a contest that lasted for over a decade, was at times extremely violent, and was part of regional history and lore for decades to come.

One could in fact argue that judicial review and enforcement of the state conditions was almost irrelevant-territories that were hungering for statehood, particularly when it had been denied for decades, as in Hawaii, Utah, and New Mexico, were hardly likely to refuse to accede to Congress's demands for conditions when they were admitted. And those territories were likely to take concrete measures to show that they would not renege on the conditions after admission. As one New Mexican said in the debates over whether New Mexico's constitution would be accepted by Congress in 1911, "We will accept anything to get statehood." 315

The long delays before admission meant that in many cases-such as in Utah, New Mexico, and Hawaii-the territorial governments and the societies within the territories were forced to adapt themselves in particular ways in order to meet with Congressional approval. Thus, Utah was not trusted with statehood until Congress was satisfied that the Mormon church had abandoned polygamy and explicit involvement in Utah politics; Hawaii was required to undertake extensive state legislation and activities to suppress Communism in the 1950s; and New Mexico had to show progress in the Americanization and assimilation of its MexicanAmerican population. Even if the conditions themselves were neither

315. Hearings before the Committee on the Territories of the House of Representatives on House Joint Resolution No. 14 Approving the Constitutions Formed by the Constitutional Conventions of the Territories of New Mexico and Arizona, 17 (1911) (statement by Judge Fall). See also the discussion in note 301, supra, regarding testimony by New Mexicans in 1911 that the constitutional convention in New Mexico did whatever was required to comply with the Enabling Act in order to achieve admission. 
necessary nor sufficient to achieve Congress's objectives in assimilating the new state, they were part of a long-term process in which those objectives were achieved.

As a result, it is not much of a surprise that there are so few cases involving the conditions imposed on states that related to state government-instead, almost all of the cases instead involve economic issues such as taxation of federal lands, or obstruction of navigation. The conditions that related to state government-outside of the South - were generally not in litigation because they were no longer contested by the states on which they had been imposed.

This history of state conditions shows that Congress, from the very beginning of the United States, has been involved in using its powers to admit states to undertake social policy, even social engineering. Other scholars have also found extensive patterns of federal governmental involvement in social policy, even in the nineteenth century. These scholars have noted the federal government's involvement with marriage policy in the territories (in particular with relation to polygamy in Utah), 316 and in the Union Army's and Freedman's Bureau's efforts during the Civil War and Reconstruction to encourage marriage among freed slaves and to require those freed slaves to accept contract labor on white plantations in the post-Civil War South. ${ }^{317}$ Scholars have also discussed the implications of federal immigration law on the citizenship of American women who married foreign citizens, and foreign women who married American citizens, and the notions of the proper role of marriage and women as citizens that these policies reflected. 318 Programs such as the post-Civil War pension schemes for Union soldiers and Social Security during the New Deal were structured in a significant way based on notions of the proper role of women and minorities in the economic system, and as a result had a great influence on the economic incentives and barriers that faced women, blacks, and other groups in society. 319

316. See Nancy F. Cott, Public Vows: A History of Marriage and the Nation 72 $75,111-120(2000)$.

317. See id. at 83-87; Linda K. Kerber, No Constitutional Right to Be Ladies: Women AND the Obligations of Citizenship 48-65 (1998). Cott has also discussed the efforts by federal Indian agents to eliminate polygamy among Native Americans. CoTT, supra note 310, at 22-26, 121-22.

318. For many years, an American woman who married a foreign citizen lost her citizenship, but a foreign woman who married an American man gained American citizenship. See COTT, supra note 310, at 133-34; KERBER, supra note 311, at 41-45.

319. See Margaret Weis, Ann Shola Orloff \& Theda Skocpol, The Politics of Social Policy IN THE UNITEd States 194-97, 287 (1988) (discussing how Social Security was designed to exclude agricultural and domestic laborers, in part to exclude blacks and women who disproportionately were concentrated in those labor markets); CoTT, supra note 310, at 173-76 (noting how Social Security provided disproportionately lower benefits to women and minorities, and benefitted married, unworking women); KERBER, supra note 
And federal legislation on interstate commerce has been, through selective enforcement of the Mann Act throughout the early part of the twentieth century, targeted against "immoral" activities such as interracial relationships and romantic affairs between single and married individuals. ${ }^{320}$

Thus, the use of conditions for the admission of the states to the Union to achieve social policy goals is just part of a larger pattern of federal government efforts to use one of its enumerated powers-the Spending Clause, the Commerce Clause, immigration and citizenship law, the Property Clause, and other tools-to achieve social policy. The history described in this paper is hardly unique. Indeed, it provides another striking example of how the lines that are drawn between categories such as "family law", "criminal law", "social welfare law", or "commerce" are at best fuzzy, and more often than not, simply misleading. 321

The history of state conditions described in this paper has significant implications for current Supreme Court jurisprudence regarding federalism. The Court has relied on lines that delineate certain areas as "truly national" and certain areas as "truly local,"322 with family law and criminal law falling on the "truly local" side of the line. 323 Yet, the history that this paper describes shows that Congress, since the early 1800 s, has considered matters such as family law (polygamy), language, and religion as issues that are of national importance-indeed, that Congress has used its powers to admit states in an attempt to fundamentally alter the society of future states to ensure that they are more compatible with the rest of the United States. ${ }^{324}$ This history raises questions about the clarity with which lines can be drawn dividing-for example-family law, a "truly local" issue, from the loyalty and readiness for self-government of a state, presumably a "truly national" issue when that state is about to be admitted to the Union.

The irony is that Coyle $v$. Smith has been one of the cases that the Supreme Court has relied upon as a fundamental marker of the core areas

311, at 72-74 (same). During the New Deal, in fact, the federal government effectively terminated all women employees who were married to male federal employees as a way of reducing unemployment among men. See CoTT, supra note 310 , at 173 .

320. See CoTT, supra note 310 , at 146-147, 163.

321. See Judith Resnik, Categorical Federalism: Jurisdiction, Gender and the Globe, 111 YALE L.J. 619 (2001).

322. U.S. v. Morrison, 120 S. Ct. 1740, 1754 (2000) (striking down a provision of the Violence Against Women Act creating a cause of action for individuals who are victims of violence that results from an animus against gender as unconstitutional because it exceeds Congress's powers under the Commerce Clause and Fourteenth Amendment)

323. Morrison, $120 \mathrm{~S}$. Ct. at 615-16.

324. See GoRDON, supra note 109, at 65 (noting that Republicans were willing to legislate on polygamy in Utah even though it was part of family law, which was perceived to be a local issue). 
of state sovereignty that the federal government can not intrude upon. ${ }^{325}$ Yet, the history of the field that Coyle $v$. Smith is a part of - the admission conditions of states-reveals a very different landscape, an area where states have been marked as different and inferior through conditions that Congress imposed to ensure their loyalty and homogeneity, an area where the sovereignty of states has been compromised so that Congress could achieve other goals that it felt were worthwhile. The reliance of the Supreme Court on Coyle as it has constructed a vision of state sovereignty as protected in certain inviolable ways is therefore extremely problematic. How can Coyle stand for the proposition that the Court has cited it for, when the Court's holding in Coyle seems almost irrelevant compared to the enormous political and social changes that some member states of the Union have gone through in order to be admitted, changes that were caused in part by the admission conditions themselves? Indeed, the facts of Coyle-where the Court refused to enforce an admission condition that restricted the movement of a state capital ${ }^{326}$ - are significantly less egregious than other conditions - official language, the banning of polygamy are the most obvious examples-that Congress has successfully imposed on newly-admitted states, and which have been part of a process that led to significant social and political changes in those states.

Even where the Court has not explicitly relied on Coyle, the manner in which admissions conditions have been used (to impose assimilation and homogeneity on theoretically sovereign members of a Union), the uneven manner in which they have been applied (on what are seen as potentially disloyal or non-homogeneous members of a Union that is theoretically made up of equal members), and the substantive areas which have been implicated (far beyond the enumerated powers of Congress) make admissions conditions a strong challenge to the constitutional vision constructed in the Supreme Court's recent Tenth and Eleventh Amendment jurisprudence, a vision of clear lines between what is federal and what is state, and of a core area of inviolable state sovereignty. ${ }^{327}$

325. See New York v. U.S., 505 U.S. 144, 162 (1992) (striking down a federal law that required states to take title to low-level radioactive waste within their borders and citing Coyle for the proposition that "The Constitution has never been understood to confer upon Congress the ability to require the States to govern according to Congress's instructions"); see also National League of Cities v. Usery, 426 U.S. 833, 845-46 (1976) (relying on Coyle v. Smith as an example of Congress going too far in regulation of states); Garcia v. San Antonio Metropolitan Transit Authority, 469 U.S. 528, 556 (1985) (overruling National League of Cities, but citing Coyle v. Smith as an example of "the affirmative limits the constitutional structure might impose on federal action affecting the States under the Commerce Clause"); $i d$. at 574 (Rehnquist, J. dissenting) (citing Coyle v. Smith as an example of "the many cases in which the Court has recozniged not only the role, but also the importance, of state sovereignty").

326. See Coyle, 221 U.S. at 563-67.

327. See, e.g., Morrison, 529 at 615-16 (holding that the Violence Against Women Act 
Instead, the history of admission conditions encourages a more thoughtful, subtle and nuanced vision of state-federal relationships in the United States. This is a vision of shared sovereignty where there are not clear substantive borders between what is "state," and what is "federal," but instead where there is more of a give and take between the state and federal. This is a vision of state sovereignty where historical context and politics have as much to say about the sharing of sovereignty as the literal text of the Constitution. Recent legal scholarship has pointed out the possibility of a more refined division of roles between the states and the federal government ${ }^{328}$ - the history of admission conditions shows that the borders between what is state and what is federal and the nature of what sovereignty means in the American federal system have always been fuzzy, unclear, and movable depending on the needs and concerns of the American people at the time. ${ }^{329}$ Perhaps our constitutional jurisprudence should acknowledge and reflect that historical reality as well.

exceeded Congress's powers under the Commerce Clause and stating that allowing an overly broad scope for Congress's Commerce Clause powers would "completely obliterate the Constitution's distinction between national and local authority because Congress could intrude into areas such as criminal law, "family law and other areas of traditional state regulation"); id. at 617 ("The Constitution requires a distinction berween what is truly national and what is truly local."); id. (stating that criminal law is "no better example of the police power, which the Founders denied the National Government and reposed in the States"); Alden v. Maine, 527 U.S. 706, 713-14 (1999) (holding that states may not be subject to suit without their consent in state court under federal law and stating that the federal system of government "preserves the sovereign status of the States" in part by protecting "the dignity and essential attributes inhering in [a] status" of holding "a substantial portion of the Nation's primary sovereignty"); id. at 728-31 (stating that sovereign immunity of the states is an essential part of state sovereignty and the federal system); id. at 732 ("When a State asserts its immunity to suit, the question is not the primacy of federal law but the implementation of the law in a manner consistent with the constitutional sovereignty of the States."); id. at 748-49 ("[O]ur federalism requires that Congress treat the States in a manner consistent with their status as residuary sovereigns and joint participants in the governance of the Nation. ... The principle of sovereign immunity preserved by constitutional design thus accords the States the respect owed them as members of the federation."); Printz v. United States, 521 U.S. 898, 928 (1997) (striking down a federal statute that required local law enforcement officials to implement a federal gun-control law as violative of the Tenth Amendment, and stating that "It is an essential attribute of the States' retained sovereignty that they remain independent and autonomous within their proper sphere of authority."); United States v. Lopez, 514 U.S. 549, 564-65 (1995) (striking down a federal law banning the possession of firearms within a certain distance of schools as exceeding Congress's powers under the Commerce Clause, and stating that upholding the statute would eliminate any barrier against Congress infringing on criminal law and family law, areas traditionally reserved for states); $i d$. at 583 (Kennedy, J., concurring) (calling the intrusion on state sovereignty in this case "significant").

328. See Resnik, supra note 315.

329. The relevance of history here is particularly significant because the Court itself has relied extensively on historical analysis in its Tenth and Eleventh Amendment jurisprudence. See, e.g., Alden, 527 U.S. at 715-30 (looking at the historical background for the Eleventh Amendment in order to interpret it); id. at 727 (stating that "we have looked to history and experience, and the established order of things" to determine the meaning of the Eleventh 


\section{APPENDIX: OVERVIEW OF CONDITIONS IMPOSED ON STATES}

Vermont (1791): No conditions were imposed by Congress on the admission of Vermont to the Union. ${ }^{330}$ However, New York's acceptance of Vermont statehood required the payment of $\$ 30,000$ to be made to extinguish New York land claims within Vermont.331

Kentucky (1792): No conditions were imposed by Congress on the admission of Kentucky to the Union. ${ }^{332}$ Virginia's acceptance of Kentucky statehood required several conditions, including acceptance of a portion of the Virginia and United States debt, a promise that "all private rights and interests in land within [Kentucky], derived from the laws of Virginia prior to such separation, shall remain valid and secure under the laws of the proposed State, and shall be determined by the laws now existing in this state", no taxation of non-resident property at a higher rate than resident property, and a guarantee that the use of Ohio River would remain free to all US citizens. 333

Tennessee (1796): No conditions were imposed by Congress on the admission of Tennessee to the Union. ${ }^{334}$ In ceding the land to the United

Amendment (quotations omitted)); Printz, 521 U.S. at 905-18 (looking at history of Congressional practice to determine whether the federal government can require a state executive official to implement federal law); $i d$. at 918 (stating that "almost two centuries of apparent congressional avoidance of the practice" of conscripting state executive officials to enforce federal laws is strongly persuasive of the meaning of the Constitution on the point); Seminole Tribe v. Florida, 517 U.S. 44, 71 (1996) (holding that Congress may not grant federal courts jurisdiction over suits against states under the judiciary's federal-question jurisdiction because the Eleventh Amendment bars such a suit, and stating that the lack of such a power is buttressed by "the fact that the Nation survived for nearly two centuries without the question of such power ever being presented to this Court").

330. An Act for the Admission of the State of Vermont into this Union, ch. 7, 1 Stat. 191 (1791).

331. Paul S. Gillies, Adjusting to Union: An Assessment of Statehood 1971-1816, in A More Perfect Union: Vermont Becomes a State, 1777-1816 114, 117 (Michael Sherman, ed., 1991); see An Act Directing the Payment of Thirty Thousand Dollars to the State of New York, and Declaring What Shall be the Boundary Line Between the State of Vermont and State of New York, ACts and Laws Passed by the Legislature of THE STATE OF Vermont 9-10 (Oct. 28, 1790); An Act Appointing Commissioner with Power to Declare the Consent of the Legislature of This State that a Certain Territory Within the Jurisdiction Thereof Should be Formed or Erected into a New State, 3 Laws of THE State of New York 125-126, ch. 18 (March 6, 1790).

332. An Act Declaring the Consent of Congress That a New State Be Formed Within the Jurisdiction of the Commonwealth of Virginia, and Admitted Into This Union by the Name of the State of Kentucky, ch. 4, 1 STAT. 189 (1791).

333. Lowell H. Harkison, Kentucky's RoAd to STATEHOOd 41-42, 73-74, 80-81 (1992); see also An Act Concerning the Erection of the District of Kentucky into an Independent State, 1789 Virginia ACTS 49, Chap. 81 (1788).

334. An Act for the Admission of the State of Tennessee into the Union, ch. 47, 1 STAT. 491 (1796). 
States, North Carolina required that Tennessee be governed by the Northwest Ordinance, that slavery be permitted in the territory, that the inhabitants pay their share of state and federal debts, that previous land grants in the territory by North Carolina be protected, and that debts contracted by residents of the new territory to North Carolina residents be enforced. 335

Ohio (1803): In exchange for the transfer of federally owned lands to the state of Ohio for the use of schools, the transfer of salt springs to the state for revenue purposes, and the payment of a fraction of all proceeds of federal land sales to the state for road construction, the federal government required Ohio to promise to never tax federal property within the state, and to not tax new purchasers of federal land for at least five years after purchase. 336 The state constitution was also required to be in conformity with the Northwest Ordinance, 337 which required the protection of religious liberty, the prohibition of slavery, protection of habeas corpus and trial by jury, democratic representation in the legislature, bail, no cruel and unusual punishments, no taking of private property, the encouragement of public schools, and fair treatment to Indians. 338 The Ordinance also prohibited new states in the Territory from interfering with "the primary disposal of the Soil by the United States," or with any "regulations Congress may find necessary for securing the title in such soil to the bona fide purchasers." 339 The Ordinance also prohibited discriminatory taxation against non-resident property owners, and required keeping all rivers "common highways, and forever free" to all citizens of the U.S "without any tax, impost or duty therefor." 340

Louisiana (1812): Louisiana was required to meet a number of fundamental conditions for admission. It was required to form a state constitution that "shall contain the fundamental principles of civil and religious liberty," that shall "secure to the citizen the trial by jury in all criminal cases, and the privilege of the writ of habeas corpus," and that after admission "the laws which such state may pass shall be promulgated, and its records of every description shall be preserved, and its judicial and legislative written proceedings conducted, in the language in which the laws and the judicial and legislative written proceedings of the United States are

335. An Act for the Purpose of Ceding to the United States of America Certain Southern Lands Therein Described, North Carolina General Assembly, ch. 3, 1 STAT. 466 (1789).

336. Ohio Enabling Act $\S 7,7^{\text {th }}$ Congress, Sess. 1 Ch. 40, 2 STAT. 173 (1802); Act modifying the Ohio Enabling Act, ch. 21, 2 STAT. 225 (1803).

337. Ohio Enabling Act $\$ 6$.

338. Section 10 of the Northwest Ordinance.

339. Id.

340. Id. 
now published and conducted." 341 Additional requirements relating to federally-owned lands within Louisiana were also imposed, including a disclaimer of all unappropriated lands owned by the United States, exemption of federal lands from state tax (including new purchasers of federal lands for five years), no discriminatory taxation against non-residents, and the maintenance of the Mississippi and all other navigable rivers as "common highways and for ever free ... without any tax, duty, impost or toll." 342

Indiana (1816): Similar conditions for the admission of Ohio were offered by Congress to Indiana. 343

Mississippi (1817): Mississippi was required to accept the Northwest Ordinance conditions for admission (except for the prohibition on slavery), to disclaim all unappropriated federal lands, to exempt federal lands from taxation (up through five years after sale to first purchaser), and to guarantee that the Mississippi would be a common highway free from taxation or toll. 344

Illinois (1818): Illinois's state constitution was required to be consistent with the Northwest Ordinance, and Illinois was required to not tax lands sold by the United States for five years, and to not tax non-resident property owners at a higher rate than resident property owners. ${ }^{345}$

Alabama (1819): Alabama was required to accept conditions similar to Ohio with regards to public lands, to accept the Northwest Ordinance (other than the provision regarding slavery), to guarantee that "all navigable waters within the said state shall for ever remain public highways, free to the citizens of said state and of the United States, without any tax, duty, impost or toll," and to never tax non-resident property owners at a higher level than resident property owners. 346

Maine (1820): Congress imposed no conditions on the admission of the state of Maine ${ }^{347}$ However, Massachusetts required Maine to accept division of state property within Maine, a division of Massachusetts debts among Maine and Massachusetts, protection of all land grants by Massachusetts within Maine prior to the separation, and no discrimination against non-resident property owners within Maine. ${ }^{348}$

Missouri (1821): Congress imposed restrictions on Missouri's ability

341. Louisiana Enabling Act \& 3, ch. 21, 2 STAT. 641 (1811)

342. Id. Acceptance of all of these conditions was made a "fundamental condition[ $]$ " of the admission of Louisiana into the Union in the Louisiana Admission Act. Louisiana Admission Act $\$ 1,1$ ch. 50, 2 STAT. 703 (1812)

343. Indiana Enabling Act $\S 4,6$, ch. 57, 3 STAT. 289 (1816).

344. Mississippi Enabling Act $\S 4$, ch. 23, 3 STAT. 349 (1817).

345. Illinois Enabling Act $\$ 4,6$, ch. 68, 3 STAT. 431 (1818).

346. Alabama Enabling Act $\$ 5,6$, ch. 47, 3 Stat. 489 (1819).

347. Maine Admission Act, ch. 19, 3 STAT. 544 (1820)

348. H.R. Doc. No. 16-3, at 25-29 (1819). 
to tax or regulate public lands within the state, as well as the traditional restriction on state taxation of federal lands and non-resident owners. ${ }^{349}$ Congress also required that, in return for grants of public lands, Missouri promise not to tax lands purchased from the United States for five years. ${ }^{350}$ Finally, the resolution admitting Missouri required that "the legislature of [Missouri], by a solemn public act, shall declare the assent of the said state" to a fundamental condition that a particular clause of the new Missouri state constitution that required the state legislature to prohibit the entrance of free blacks into the state "shall never be construed to authorize the passage of any law, and that no law shall be passed in conformity thereto, by which any citizen, of either of the states in this Union, shall be excluded from the enjoyment of any of the privileges and immunities to which said citizen is entitled under the constitution of the United States." 351

Arkansas (1836): The same conditions regarding public lands that were made applicable to Missouri were explicitly made applicable to Arkansas. ${ }^{352}$

Michigan (1837): Michigan was admitted on condition that it consented to the cession of any claims to certain territory within Ohio, that it shall not have any authority to interfere with the sale or regulation of federal land, and that it could not tax federal lands within the state. Similar public lands conditions as were imposed on Missouri and Arkansas were imposed on Michigan in return for grants of federal land to the state. 353

Florida (1845): Florida was required to "never interfere with the primary disposal of the public lands lying within [its borders], nor levy any tax on the same whilst remaining the property of the United States." 354

Texas (1845): The joint resolution that admitted Texas required Texas to cede all military fortifications, but allowed Texas to keep all public lands and required it to pay its own debts from the independence period. It also required that any portion of Texas north of the Missouri

349. "[T] he legislature of [Missouri] shall never interfere with the primary disposal of the soil by the United States, nor with any regulations Congress may find necessary for securing the title in such soil to the bona fide purchasers; and that no lax shall be imposed on lands the property of the United States; and in no case shall non-resident proprietors be taxed higher than residents." Missouri Enabling Act $\$ 4,16^{\text {th }} \mathrm{ch} .22,3$ STAT. 545 (1820).

350. Id. $\$ 6$. This condition is very similar to the ones imposed on Ohio, Indiana and Illinois regarding public lands.

351. Missouri Admission Resolution, Res. 1, 3 STAT. 645 (1821). This resolution was a compromise of a long and bitter debate over the appropriateness of Missouri's prohibition on the settlement of free blacks within the state.

352. Arkansas Admission Act, ch. 100, 5 STAT. 51 (1836); Arkansas Supplementary Admission Act, ch. 120, 5 STAT. 58 (1836).

353. Michigan Admission Act, 24th Cong. Sess. 1 Ch. 99 (1836); Michigan Supplementary Admission Act, 24th Cong. Sess. 1 Ch. 121 (1836); Michigan Admission Act, ch. 6, 5 STAT. 144 (1837).

354. Iowa and Florida Admission Act, ch. 63, 8 STAT. 742 (1845) 
Compromise line be admitted without slavery. 355

Iowa (1846): Iowa was required to accept the same conditions as for Florida, and to never tax non-resident property owners higher than resident property owners. ${ }^{356}$

Wisconsin (1848): Wisconsin was required to guarantee that all navigable rivers leading into the Mississippi "shall be common highways, and forever free" without "any tax, duty, impost or toll." 357 In return for the grant of federal lands to the state, Wisconsin was to promise the same conditions as Iowa. 358

California (1850): California was admitted with similar conditions as Wisconsin. 359

Minnesota (1858): Minnesota was admitted with essentially the same conditions as Wisconsin. 360

Oregon (1859): Oregon was admitted with essentially the same conditions as Wisconsin. 361

Kansas (1861): Congress provided that the admission of Kansas was not to impair any of the rights of Indians within the state. In return for public land grants, Kansas was required to assent to never interfering with the disposal of federal lands or any regulations to secure title to purchasers of federal lands, and to never tax federal property in Kansas. ${ }^{362}$

West Virginia (1863): West Virginia was required to alter the timing of the emancipation of slaves as a condition for admission. No other conditions were imposed. ${ }^{363}$

Nevada (1864): Nevada was required to prohibit slavery, and to guarantee "perfect toleration of religious sentiment."364 Standard conditions as to disclaiming any rights as to federal land within the state, to not tax non-resident property at a higher rate than resident property, and to not tax federal property within the state were also imposed. 365

355. Joint Resolution for Annexing Texas to the United States, Res. 8, 8 STAT. 797 (1845).

356. Iowa and Florida Supplementary Admission Act, ch. 76, 8 STAT. 789 (1845).

357. Wisconsin Enabling Act $\S 3$, ch. 89, 9 STAT. 56 (1846).

358. Id. \& 7 .

359. California Admission Act $\S 3$, ch. 50, 9 STAT. 452 (1850). Of course, the navigable rivers provision for California applied to all rivers in the state, not rivers that flowed into the Mississippi.

360. Wisconsin Enabling Act, ch. 60, 10 STAT. 166 (1857).

361. Oregon Admission Act, ch. 33, 11 STAT. 383 (1859).

362. Kansas Admission Act, ch. 20, 12 STAT. 126 (1861).

363. West Virginia Admission Act, ch. 6, 12 STAT. 633 (1863).

364. Nevada Enabling Act $\$ 4$, ch. 36, 13 STAT. 30 (1864).

365. Id. Similar conditions were placed in the enabling acts for Colorado and Nebraska in 1864, see Colorado Enabling Act, ch. 37, 13 STAT. 32 (1864), but Colorado did not ratify a constitution within the time limits and restrictions that Congress provided for under the Enabling Act. 
Nebraska (1867): Nebraska was required to meet the same conditions as Nevada in its Enabling Act. 366 When Nebraska was actually admitted into the Union, it was required to change its constitution to climinate any racial barriers to voting. 367

Colorado (1875): Colorado's second Enabling Act required the state to meet the same conditions as Nevada. ${ }^{368}$

Montana, Washington, South Dakota, North Dakota (1889): All four of these states were required to meet the same conditions as Nevada, to disclaim any right or title to all Indian lands, to assume territorial debts, and to maintain public schools open to all children that are "free from sectarian control." 369 Additional restrictions on the sale of lands granted to the state by the federal government were also imposed. 370

Idaho (1890): Idaho was admitted with only conditions regarding the resale of state grant lands and restrictions on the use of funds from state grant lands similar to those imposed on the states admitted in 1889.371

Wyoming (1890): Wyoming was also admitted with only conditions regarding the resale of state grant lands and restrictions on the use of funds from state grant lands similar to those imposed on the states admitted in 1889.372

Utah (1896): Utah was admitted on the condition that its constitution "make no distinction in civil or political rights on account of race or color," that the constitution provide " $[t]$ hat perfect toleration of religious sentiment shall be secured," that the constitution provide "[t]hat polygamous or plural marriages are forever prohibited," and that the constitution provide for the establishment and maintenance of public schools free from sectarian control. ${ }^{373}$ Utah was also required to meet the usual conditions regarding public lands: disclaim rights to all federal lands in Utah and to all Indian lands within the state, promise not to tax non-resident property at a higher rate, and promise not to tax federal property ${ }^{374}$ Restrictions on the rental and resale of lands granted to the state, and on the use of funds from the rental or resale of those lands, similar to the states admitted in

366. Nebraska Enabling Act, ch. 59, 13 STAT, 47 (1864).

367. Nebraska Admission Act, ch. 36, 13 STAT. 39I (1867).

368. Colorado Enabling Act $\$ 4$, ch. 139, 18 Stat. 474 (1875).

369. North Dakota, South Dakota, Montana and Washington Enabling Act $\S 4$, ch. 180, 25 STAT. 677 (1889).

370. These restrictions included minimum sale prices, maximum lease periods, restrictions on the use of funds from the sale of those lands to the specific purposes, prohibition on the use of funds for sectarian schools. See id. \$\$ 9, 11-14, 17.

371. Idaho Admission Act, ch. 656, 26 STAT. 215 (1890).

372. Wyoming Admission Act, ch. 664, 26 STAT. 222 (1890).

373. Utah Enabling Act $\S 3$, ch. 138, 28 STAT. 107 (1894).

374. Id. 
1889 and 1890 were also provided. 375

Oklahoma (1907): Oklahoma and the Indian Territory's admission as the state of Oklahoma was specifically conditioned on the federal government's reserving and protecting all Indian rights within the territory. ${ }^{376}$ The Osage Reservation was required to be incorporated as a single county within the state. ${ }^{377}$ The state capital was to be maintained at Guthrie until 1913 , and the state government was limited as to the number of public buildings it could construct in Guthrie until 1913.378 The state constitution was to protect religious freedom, to prohibit polygamy forever, and to prohibit the liquor trade in the former Indian Territory for at least twentyone years after admission. ${ }^{379}$ By now standard conditions as to the disclaimer of federal and Indian lands within the state, equality of taxation for non-residents, and no taxation of United States property, were provided. ${ }^{380}$ The public school system was to be "open to all the children of said State and free from sectarian control; and said schools shall always be conducted in English." 381 The state was also to "never enact any law restricting or abridging the right of suffrage on account of race, color, or previous condition of servitude." 382 Public lands and moneys granted by the federal government to the state for educational purposes were to be used only for the state school system. ${ }^{383}$ Restrictions as to the leasing, sale, advertisement for sale and leasing of public lands granted to the state were also imposed. 384

New Mexico (1912): New Mexico was required to meet many of the same conditions that Oklahoma had to meet: "no distinction in civil or political rights on account of race or color," "perfect toleration of religious sentiment," "polygamous or plural marriages, or polygamous cohabitation" was to be prohibited forever, "the sale, barter, or giving of intoxicating liquors to Indians" was to be prohibited forever. ${ }^{385}$ The state was also to disclaim all rights to federal or Indian lands within the state, to tax non-resident property equally with resident property, to never tax

375. Id. $\$ \$ 8-12$. No minimum resale price requirement was imposed, however.

376. Oklahoma Enabling Act $\S 1$, Pub. L. 234, 34 STAT. 267 (1906)

377. Id. \& 21 .

378. ld. $\S 3$.

379. Id. The provisions as to prohibition in the Indian Territory were especially detailed as to how the state would regulate the sale of denatured and medicinal alcohol, and the penalties to be provided for violations of the law.

380. Id.

381. Id.

382. Id.

383. Id. $\S \S 7-12$.

384. $l d$.

385. Arizona and New Mexico Enabling Act $\S 2$, Pub. L. 219, 36 StAT. 557 (1910). 
federal property, to assume all territorial debts (except for invalid bonds), to provide for a public school system "open to all the children of said State and free from sectarian control, [with] said schools . . . always be conducted in English." 386 The state was also to never abridge suffrage on the account of race, but was also required to ensure that "ability to read, write, speak, and understand the English language sufficiently well to conduct the duties of office without the aid of an interpreter shall be a necessary qualification for all State officers and members of the state legislature."387 The capital was to remain in Santa Fe until 1926.388 Prohibition was to continue in Indian reservations for at least twenty-five years after statehood. ${ }^{389}$ Restrictions on the lands and moneys granted to the state for various purposes were even stricter than in previous statehood laws; the lands and proceeds from the sale and rental of the lands were to be held in trust for the purposes for which they were granted. 390 The mortgaging, sale and leasing of the lands were strictly controlled by Congress, with specific rules for the timing, advertising and duration of sales and leases. ${ }^{391}$ Minimum prices were also imposed, and a right of enforcement for all of these land provisions was given to the U.S. Attorney General. ${ }^{392}$ New Mexico's Admission Act required the state to vote on an amendment to the state constitution that would make changes to the constitution easier to ratify. ${ }^{393}$

Arizona (1912): The same conditions were in Arizona's Enabling Act as in New Mexico's. ${ }^{394}$ Arizona's Admission Act required the state to repeal a provision of its state constitution that provided for recall of judges. 395

Alaska (1959): Alaska was required to disclaim all right and title to any federal lands, and to use all school lands and funds for a public school system free from sectarian control ${ }^{396}$

Hawaii (1959): Hawaii was required to establish and maintain an agency to run the Hawaiian home lands for the benefit of native Hawaiians. 397

386. $I d$.

387. $1 d$.

388. Id.

389. $I d$.

390. Id. \$10.

391. Id.

392. $I d$.

393. Arizona and New Mexico Admission Joint Resolution § 3, S.J. Res. 57,37 STAT. 39 (1911) The resolution also repealed the requirement in the Enabling Act that New Mexico's public officers and officials speak and write English. $I d$. $\$ 6$.

394. Arizona and New Mexico Enabling Act, \$§ 20-30.

395. Arizona and New Mexico Admission Joint Resolution $\S 7$.

396. Alaska Admission Act $\$ 4$, Pub. L. 85-508, 72 STAT. 339 (1958).

397. Hawaii Admission Act $\$ 4$, Pub. L. 86-3, 73 STAT. 5 (1959). 
Reconstruction Acts (1868-1870): The former Confederate states of Virginia, North Carolina, South Carolina, Georgia, Florida, Alabama, Mississippi, Alabama, Arkansas, Louisiana, and Texas were required to be readmitted to the United States before their Congressional representatives would be accepted by the Reconstruction Congress. These states were required to ratify the Fourteenth Amendment before readmission, and to not discriminate on the basis of race with respect to suffrage. ${ }^{398}$ Most of these states also had additional conditions imposed on their final readmission, including the requirement that the states never abridge the suffrage rights of all current citizens. ${ }^{399}$ Virginia, Mississippi and Texas were also required to promise to never pass a law excluding blacks from public office, and to never amend their constitution to deprive blacks of any school privileges they held under one Reconstruction Constitutions. 400

398. First Reconstruction Act, Ch. 153, 14 STAT. 428 (1867). The Reconstruction Acts were, in effect, the enabling acts for the readmission of the Southern states.

399. "[T]he constitutions of neither of said States shall ever be so amended or changed as to deprive any citizen or class of citizens of the United States of the right to vote in said State, who are cntitled to vote by the constitution thereof herein recognized, except as a punishment for such crimes as are now felonies at common law, whereof they shall have been duly convicted under laws equally applicable to all the inhabitants of said state." An Act to admit the States of North Carolina, South Carolina, Louisiana, Georgia, Alabama and Florida to Representation in Congress, Ch. 70, 15 STAT. 73. (1868); see also An Act to admit the State of Arkansas to Representation in Congress, Ch. 69, 15 STAT. 72 (1868).

400. "[I]t shall never be lawful for the said State to deprive any citizen of the United States, on account of his race, color, or previous condition of servitude, of the right to hold office under the constitution and laws of said State, or upon any such ground to require of him any other qualifications for office than such as are required of all other citizens," and "the constitution of Virginia shall never be so amended or changed as to deprive any citizen or class of citizens of the United States of the school rights and privileges secured by the constitution of said State." An Act to admit the State of Virginia to Representation in the Congress of the United States, Ch. 10, 16 STAT. 62, 63 (1870); see also An Act to admit the State of Mississippi to Representation in the Congress of the United States, Ch. 19, 16 STAT. 67, 68 (1870); An Act to admit the State of Texas to Representation in the Congress of the United States, Ch. 39, 16 STAT. 80, 81 (1870). These three states were also required to administer the "iron-clad oath" to all office holders (in which the officeholder swore that he had never taken an oath of loyalty to the United States as an officer of the United States, and then engaged in rebellion). 